\title{
12. RELATIONSHIPS BETWEEN DIAGENESIS AND PHYSICAL PROPERTIES OF BIOGENIC SEDIMENTS OF THE ONTONG-JAVA PLATEAU (SITES 288 AND 289, DEEP SEA DRILLING PROJECT)
}

\author{
Gerrit J. van der Lingen, Sedimentation Laboratory, New Zealand Geological Survey, Christchurch, New Zealand \\ and \\ Gordon H. Packham, Department of Geology and Geophysics, University of Sydney, NSW, Australia
}

\begin{abstract}
The Ontong-Java Plateau is a large oceanic plateau north of the Solomons Island, covered with a thick sequence of subhorizontal strata of predominantly biogenic sediments. The sediments sampled at the two sites drilled on this plateau during Leg 30 of the Deep Sea Drilling Project are well suited for progressive-diagenesis studies.

At Site 288, 988.5 meters of sediment were penetrated. Oldest sediments are Aptian limestones. No igneous basement was reached. Stratigraphic hiatuses occur at several levels. Chert horizons are present from exceptionally young sediments (early Miocene, $267 \mathrm{~m}$ ) downwards. At Site 289 basaltic basement was reached after drilling through 1271 meters of sediment. Oldest sediments are Aptian limestones. Chert is present below 1000 meters, in Eocene and older sediments.

For both sites the stratigraphic columns are compared with downhole plots of lithologic and physical data, viz, drilling disturbance, induration, percentage of siliceous fossils, calcium carbonate content, seismic reflectors, porosity, bulk density, and sonic velocity. Drilling disturbance correlates reasonably well with the overall changes in induration from ooze to chalk to limestone. At Site 288 the boundary between ooze and chalk is well defined, while at Site 289 the induration of ooze to chalk is intermittent right up to the change to limestone at about 1000 meters. The later chalk ooze relationship is probably due to the absence of chert at this level at Site 289. At Site 288 there is a transition zone between chalk and limestone, while at Site 289 the transition from ooze/chalk to limestone is sharp. At both sites there is a reversal in induration to ooze in the Maestrichtian, though a difference of about 600 meters subbottom depth for this level exists between the two sites.

At Site 288 the porosity decreases, and the bulk density and sonic velocity increase with depth. There are several sudden changes in all three parameters at levels related to induration and composition (especially silica content) of the sediments. In contrast, at Site 289 these three parameters change gradually, without any jumps, to about 1000 meters depth. The sudden change in values below 1000 meters is due mainly to the presence of chert, and, the associated abrupt change in induration.

The presence of silica at Site 288 significantly complicates the picture of progressive carbonate diagenesis, as shown in scanning electron photomicrographs. The relatively silica-free carbonate sediments in the top thousand meters at Site 289 provide a better picture. The aspects of progressive carbonate diagenesis are broadly similar to those described in earlier papers by the present and other authors. Dissolution and precipitation of calcite seems to take place simultaneously. Reprecipitation of secondary calcite begins on discoasters. Subsequently, new calcite is formed on the edges and in the central parts of coccoliths, as well as on micarb particles (fossil fragments). In the next stage, secondary calcite bridges the space between proximal and distal shields of coccoliths, and euhedral calcite crystals grow inside foraminiferal chambers. The secondary calcite overgrowth is the major agent in welding particles together. Further calcite precipitation is indicated by more and more euhedral crystal faces on overgrown fossil particles. Porosity decreases gradually. In the most advanced diagenetic stage all fossil particles
\end{abstract}


are covered with secondary calcite, foraminiferal chambers are completely filled with new calcite, and most of the original pore space is taken up by secondary calcite.

Silica diagenesis takes place in several ways: the formation of quartzose chert nodules; the formation of silica spherules; the replacement and infill of microfossil tests (silicosphere); and the coating and bridging of microfossil particles by smooth "icing sugar" silica.

The correlation of seismic reflectors with diagenetic changes is not always straightforward. A list of possible causative factors is compiled from the present data and from data obtained by the authors during Leg 21 .

Several fundamental questions in the understanding of diagenesis of biogenic sediment still remain: (1) is quartzose-chert formation an early diagenetic process?; (2) are (cristobalite-tridymite) silica spherules an intermediate stage in the formation of quartzose chert, or are they formed as an independent phase, late diagenetic and associated with volcanic material?; (3) how much is carbonate diagenesis influenced by silica diagenesis?; (4) can paleooceanographic chemistry explain reversals in progressive carbonate diagenesis?; (5) how much is diagenesis influenced by heatflows, decreasing in time, etc?

\section{INTRODUCTION}

Deep-sea drilling has made it possible to study diagenetic processes in deep-sea sediments in great detail. Scattered through the Initial Reports series of the Deep Sea Drilling Project are many observations as well as specific papers on diagenesis. In the early stages most of the observations and papers dealt with specific aspects of diagenesis only (Pimm et al., 1971; Moberly and Heath, 1971; Heath and Moberly, 1971; von der Borch et al., 1971; Lancelot and Ewing, 1972; Kastner and Siever, 1973; von Rad and Rösch, 1972; Berger and von Rad, 1972; Heath, 1973; Lancelot, 1973). Since it became possible, because of improved drill bits, to drill through thick chert-bearing sequences, more complete studies of progressive diagenesis with depth (up to 1300 $\mathrm{m}$ ) and in time (up to Late Jurassic) could be made (Schlanger et al., 1973; Packham and van der Lingen, 1973; Matter, 1974). At the time of writing this paper, Volume 23 of the Initial Reports of the Deep Sea Drilling Project had just been published. Some papers on diagenesis, based on DSDP material, also appeared outside the Initial Reports series.

Most diagenesis studies have concerned themselves with biogenic sediments. Matter (1974), however, also describes progressive diagenesis in a thick $(1300 \mathrm{~m})$ terrigenous pelitic sediment sequence, drilled in the Indus Cone in the Arabian Sea (Site 222).

It was a lucky coincidence that the first commercial scanning electron microscope came on the market in 1965 , only three years before the beginning of the Deep Sea Drilling Project. Scanning electron microscopy has been essential in the study of diagenesis.

The present authors studied the relationships between the progressive diagenesis of biogenic sediments, their physical properties, and seismic reflectors, from material and data collected during drilling in the southwest Pacific (Leg 21; Packham and van der Lingen, 1973). The same line of investigation is followed in the present paper. For this study, Sites 288 and 289, on the Ontong-Java Plateau, were chosen. The sedimentary sequences at these sites are almost purely biogenic.

\section{EARLIER STUDIES OF PROGRESSIVE DIAGENESIS IN BIOGENIC SEDIMENTS}

In dealing with the diagenesis of biogenic sediments, carbonate and silica diagenesis should be discussed separately. The two processes are largely independent, physicochemically, as well as time-wise.

\section{Carbonate Diagenesis}

Schlanger et al. (1973) studied progressive diagenesis in biogenic sediments at Site 167. This site is situated on the Magellan Rise, a large oceanic plateau in the central Pacific. The hole bottomed in extrusive oceanic basalts after penetrating 1172 meters of sediment. The age of the sediment immediately overlying basalt is Late Jurassic (Tithonian-Berriasian). The diagenetic changes from ooze to chalk to limestone were studied in detail. The authors proposed a diagenetic model for these changes (carbonate component only): $3.0 \mathrm{cc}$ of foramnannofossil ooze (density 1.35 ; porosity $80 \%$ ) changes to $1.7 \mathrm{cc}$ of foram-nannofossil chalk (density 1.60 ; porosity $65 \%$ ), which changes to $1.0 \mathrm{cc}$ of nanno-bearing limestone (no forams; density 2.0 ; porosity $40 \%$ ). The changes take place through tighter packing (early stages), mechanical breakdown of some fossils (a very minor contributor to compaction), and by progressive dissolution of an "easily dissolved calcite phase" (mainly foram calcite, but also some nannofossil calcite), and simultaneous reprecipitation on a more stable calcite phase. For their model, they accept that the system is "calcite conservative," that is, no introduction of carbonate from an outside source is required.

Packham and van der Lingen (1973) studied progressive carbonate diagenesis in sediments at four sites in the southwest Pacific: Site 206 in the New Caledonia Basin, Sites 207 and 208 on the Lord Howe Rise, and Site 210 in the Coral Sea Basin. The bulk of the sediments are biogenic, apart from a silty claystone unit at the base of the sediment sequence at Site 207, and a terrigenous turbidite sequence (intercalated with nannofossil layers) in the upper part of Site 210. The oldest sediments studied are Maestrichtian (Sites 207 and 208), 
and the deepest sediment penetration was 734 meters (Site 206). An effort was made to correlate scanning electron microscope observations with physical sediment properties such as drilling disturbance (or deformation of cores), induration (degree of lithification), bulk density, and sonic velocity. Correlation of all these data with seismic reflectors was only partly successful. Possible correlations are: (1) where the biogenic ooze changes from "creamy" to "stiff" (induration); (2) at levels where the sediments become "crumbly" in the "stiff" zone (induration); (3) at the stiff-semilithified boundary, where welding of particles begins; (4) at the level where the bulk density starts to increase more rapidly with depth, a transition also characterized by a pronounced decrease in porosity and the beginning of granular calcite overgrowth.

The presence of a regional hiatus in all four holes, straddling the Eocene-Oligocene boundary, enabled the relative importance of time and depth of burial in relation to diagenesis to be evaluated. No simple relationship could be detected. Diagenesis seems to be dependent on both the depth and the duration of burial.

Matter (1974) studied the diagenesis in carbonate (Leg 23, Sites 220 and 223) and noncarbonate (Site 222) sediments in the Arabian Sea. Maximum age of the carbonate sediments is early Eocene (Site 220), and maximum depth of carbonate sediments was 657 meters (Site 223). His findings on progressive carbonate diagenesis supports and widens the findings of both Schlanger et al. (1973) and Packham and van der Lingen (1974). Matter also stresses the opinion that there is no need for the introduction of carbonate from an outside source. The calcite for cementation comes from the dissolution of "supersoluble" grains and from pressure solution at grain contacts. He calls this dissolution-reprecipitation process "autolithification."

\section{Silica Diagenesis}

In most biogenic sediments there is a siliceous-fossil component of varying magnitude. As pointed out by many authors, biogenic opal seems to be the main source for the ubiquitous deep-sea cherts (e.g., Heath and Moberly, 1971; Wise and Kelts, 1972; Heath, 1973; Lancelot, 1973; van der Lingen et al., 1973). Fundamental, yet unsolved problems exist in the understanding of silica diagenesis. One of these is the question whether cristobalite is an intermediate phase in the formation of chert between opaline silica and quartz. Another problem is whether chert formation is an early diagenetic process or not. These two problems will be discussed shortly

\section{The Cristobalite Problem}

Early in the Deep Sea Drilling Project tiny (3 to $12 \mu \mathrm{m}$ spherical authigenic silica blade aggregates were discovered in Oligocene chalks of the South Atlantic (Wide and Hsü, 1971). X-ray data of insoluble residues suggested that the "silica" aggregates might be clinoptilolite. Similar spherical aggregates ("botryoidal structures") from silicified chalks in the Netherlands and Belgium were described earlier in the same year by Buurman and van der Plas (1971). From analytical data they concluded that the aggregates are "badly crystalline tridymite." Since then, similar spherical aggregates were found to be a common diagenetic silica mineral in deepsea sediments. They have been given various morphological names, such as "spherules" (Wise et al., 1972; "microspheres" (Oehler, 1973); and "lepispheres" (= spheres of blades, Wise and Kelts, 1972).

It should be noted, however, that not all silica spherules are spheres of blades. At least two other morphological types have been noted. Matter (1974) depicts spherules consisting of vermiform crystal elements. Another form shows indistinct crystallinity, or at most a "sugary" surface (Lancelot, 1973; this study, Figure 31).

Quite a lot of analytical work has now been done on these spherules. Some of the mineralogical terms given are: "poorly crystallized cristobalite" (Heath and Moberly, 1971; "disordered cristobalite" (Lancelot, 1973); "low cristobalite" (Matter, 1974); " $\alpha$ cristobalite" (Weaver and Wise, 1972); "lussatite" or "opal-CT" (Berger and von Rad, 1972; Heath, 1973; Greenwood, 1973). Heath (1973) suggested that the $\alpha$ cristobalite structure can be interposed with tridymite layers. Oehler (1973) synthesized silica microspheres. He concluded that the crystal habit resembles tridymite rather than cristobalite, and suggests that "both the synthetic microspheres and the deep-sea microspheres may be composed of hybrid crystals of interlayered cristobalite and tridymite" (p. 64). Packham and van der Lingen (1973) described silica spherules from a noncalcareous Maestrichtian silty claystone (p. 504, Plate 4, fig. 2 and 3). As the bulk X-ray data for this silty claystone indicate, apart from other components, $69 \%$ cristobalite and $12 \%$ tridymite, it seems likely that the spherules are a combination of these two minerals. From the available data it can therefore be concluded that the silica spherules are hybrid aggregates of $(\alpha-$ or low-) cristobalite and tridymite. It may well be that these minerals form a series with pure $\alpha$-cristobalite and tridymite as end members.

Because of the variations in morphology and in mineralogy, the present authors will use the more general term "silica spherules."

Regardless of their morphology or mineralogy, the silica spherules are often associated with euhedral crystals of clinoptilolite. This explains why Wise and Hsü (1971) detected clinoptilolite in the insoluble residue of Oligocene chalk containing silica spherules. Clinoptilolite, a high-silica member of the heulandite zeolite group, is generally found as an alteration product of volcanic ash and tuff (Deer et al., 1963). This raises the question whether both clinoptilolite crystals and silica spherules can be derived from volcanic material. This question is discussed by Wise and Kelts (1972). They argue that some excess silica becomes available during the alteration of volcanic glass to clinoptilolite, and that this excess could precipitate as cristobalite. However, they reason that such a reaction could not produce enough silica to account for the large volumes of chert present in deep-sea sediments. They agree with many other authors that most silica reprecipitated as chert (cristobalitic or quartzitic) is derived from the tests of siliceous organisms.

Cristobalite has generally been considered as an intermediate stage in the formation of chert in deep-sea sediments (Heath and Moberly, 1971; Weaver and 
Wise, 1972; Wise et al., 1972; Wise and Kelts, 1972; Heath, 1973; Greenwood, 1973). However, in a recent paper Lancelot (1973) questions this theory. In an excellent study of silica diagenesis in sediments at Site 167 of the Deep Sea Drilling Project (Leg 17), he puts forward an alternative theory. He distinguishes two main types of chert, porcelanitic chert, which is composed predominantly of disordered cristobalite, and quartzose chert, composed of quartz and/or chalcedony. The first type occurs in marly or clayey sediments, often as thin beds or as sediment impregnation. It forms where foreign cations find a place in the disordered structure of the cristobalite. Clay minerals are considered a likely source for such cations. Low permeability also favors the formation of disordered cristobalite. The second type is found in relatively pure (siliceous fossil-bearing) carbonate sediments. The absence of foreign cations and high permeability seem to favor the precipitation of quartz (chalcedony) directly from dissolved biogenic opal and in the form of nodules. Some quartzose chert nodules have a rim of cristobalite. In this transition zone between chert and matrix, impurities are concentrated, creating a microenvironment conducive to the formation of cristobalite. Lancelot thinks that "maturation," the process of converting metastable disordered cristobalite into stable quartz, plays only a minor role in the diagenesis of deep-sea sediments. It could take place under exceptional conditions of high temperature and great overburden.

This interesting theory warrants further verification and study. Because of the common association of silica spherules and clinoptilolite crystals, the importance of volcanic material as a source for foreign cations (and free silica) should be investigated. The question should also be put whether clinoptilolite can be an alteration product of nonvolcanic material.

\section{Early or Late Diagenesis}

Because Neogene sediments hardly ever contain chert, it is generally thought that chert formation is dependent on time (the earlier mentioned "maturation process"). It was again Lancelot (1973) who questions this opinion and puts forward strong arguments in favor of chert being an early diagenetic product.

It does not seem that this question can be given a final answer at the present time. Careful sorting and synthesizing of all DSDP data no doubt will bring us close to solving this problem. However, because of the above discussion of the cristobalite problem, the present authors are of the opinion that the question of whether chert formation is early diagenetic or not should be answered separately for quartzose chert and for cristobalitic (tridymitic) chert.

\section{THE ONTONG-JAVA PLATEAU SITES}

Lithological, chemical, and physical data of the sediments drilled at Sites 288 and 289 are summarized in Figures 1 and 2 . These data will be discussed first, followed by a detailed description of the scanning electron microscopic features of the sediments. Subsequently, a correlation with seismic reflectors will be attempted. And finally tentative generalizations on the diagenesis of deep-sea biogenic sediments will be presented and problem areas outlined, incorporating information from earlier publications.

The regional geologic setting of the Ontong-Java Plateau is discussed in detail elsewhere in this volume, and will not be repeated here.

\section{Lithology}

At Site 288, 988.5 meters of sediment were penetrated. No igneous basement was reached. Coring was discontinuous. The oldest sediments cored are Aptian. Stratigraphic hiatuses were encountered at several levels. Eocene sediments are probably missing altogether. The Tertiary sequence is thinner than at Site 289, while a thicker, fairly complete Late Cretaceous sequence is present. From the base of the sequence up to the Coniacian, volcanic ash and tuff beds are intercalated. Glass shard ash is present in early Miocene sediments and younger. Chert is present from the bottom of the hole up to early Miocene.

At Site 289, the drill hole bottomed in extrusive oceanic basalt, after penetrating 1271 meters of sediment. Coring was continuous. The oldest sediments cored have the same age as those at Site 288. The Neogene sequence appears to be complete. Several hiatuses were encountered in the Paleogene and in the Cretaceous. Ash-bearing (or tuffaceous) horizons are present in the Cretaceous and the Paleocene. The volcanic debris forms a minor component only, with the exception of two fairly pure tuff beds near the base of the sedimentary sequence. Chert is present in the lower part of the sequence up to the middle Eocene.

\section{SEM Samples}

Twenty-nine samples from Site 288 and 38 from Site 289 were studied with the scanning electron microscope. Their positions are indicated on Figures 1 and 2. The results will be described further on.

\section{Drilling Disturbance}

Drilling disturbance is mainly a function of the induration of the sediments. However, drilling procedures, such as different rates of water circulation, also affect the disturbance of the cores. Drilling disturbance is estimated onboard the ship during visual core description. Such estimates are rather subjective, and only the broad pattern should be taken into account. The drilling disturbance is given numerical values from 1 to 4: 1 means no deformation of internal sedimentary structures; 2 means gently deformed structures; 3 means strong deformation, but some structures are still visible; and 4 means almost total destruction of structures through mixing and homogenization. The results can best be discussed in combination with the induration data.

\section{Induration}

This column is separated into two parts, the first giving the induration adjectives to the rock names in the second part. As with the drilling disturbance, estimating induration is somewhat subjective. The sediment is considered creamy and stiff when the cores can be cut with a wire cheesecutter. The term ooze is used for unindurated biogenic sediment. When the splitting of cores requires 
the use of a bandsaw, the sediment is considered to be semilithified and is called a chalk when dealing with predominantly carbonate sediments. When further induration of the rock requires the use of a diamond saw for splitting the cores, the sediment is considered to be lithified, and, in the case of carbonate sediment, is called a limestone.

At Site 288 the boundaries between ooze and chalk and between chalk and limestone are reasonably well defined. There is a thin transition zone between ooze and chalk (at about $130 \mathrm{~m}$ ). In the chalk interval there is a reversal horizon (to ooze) in the Maestrichtian (between 573 and $580 \mathrm{~m}$ ). A larger transition zone exists between chalk and limestone. The drilling disturbance drops at about the ooze-chalk boundary. Another one occurs within the chalk interval.

At Site 289 the boundary between ooze and chalk is not well defined. Below the level where the sediment is first called a chalk (at about $243 \mathrm{~m}$ ), ooze and chalk intervals alternate. It is not always easy to decide whether the sediment is still an ooze, or should be called a chalk. In such cases the term "chalk/ooze" has been used in the core logs. There is a gradual downward increase in the amount of chalk. However, ooze horizons persist up to the level where the sediment becomes a limestone (at about $1007 \mathrm{~m}$ ). A reversal in induration (to ooze) occurs in the limestone interval at about 1185 meters. This reversal horizon has the same age as the reversal in the chalk interval at Site 288. Major drops in drilling disturbance occur at the ooze and ooze (-chalk) boundary, and at about the level where chalk becomes the predominant rock type.

\section{Siliceous Fossil and Calcium Carbonate Percentages}

Core averages of percentages of siliceous fossils, as determined from smear slides onboard the ship, have been plotted in the next column. Percentage estimates in smear slides have a limited accuracy, and only general trends should be considered.

At Site 288, siliceous fossils are present in small quantities only, up to a core average of $6 \%$. Between 450 and 750 meters no siliceous fossils were seen. Chert is present in the lower part of the sequence up to the early Miocene, suggesting that larger amounts of siliceous fossils must have been present originally.

At Site 289 the amount of siliceous fossils slightly increases downwards, from an average of $2 \%$ at the top to $6 \%$ at about 960 meters. Below this there is a sudden increase, with wild fluctuations. This increase coincides with the Eocene-Oligocene boundary. The fluctuations are probably due to local dissolution of siliceous fossils and reprecipitation of the silica as chert nodules. Below 1050 meters no siliceous fossils have been observed. They either have been completely dissolved, or have been transformed to silicospheres (see description of SEM samples).

Calcium carbonate percentages were determined in the DSDP shore laboratory. The values, plotted in the same column as the siliceous fossil percentages, are not core averages, but represent individual spot samples, taken onboard the ship. Also compare with bulk X-ray analyses (Table 1).
At Site 288 the calcium carbonate percentages fluctuate between $90 \%$ and $100 \%$, between 100 and 700 meters subbottom depth. The lower values above 100 meters probably reflect the presence of volcanic ash, while the lower percentages below 700 meters reflect the presence of both ash and silica.

At Site 289 calcium carbonate percentages fluctuate between $90 \%$ and $100 \%$ over most of the sequence. Only one lower value of $51 \%$ was recorded at 1037 meters, in the interval with larger amounts of siliceous fossils. The almost pure carbonate samples below 1100 meters are probably from sediments in which all siliceous fossils have been dissolved and the silica reprecipitated elsewhere as chert nodules. Nonsystematic sampling onboard the ship has produced results not entirely representative for all lithologic changes. Analyses of bulk samples would no doubt have given a truer picture.

\section{Seismic Reflectors}

The estimated depths of seismic reflectors are given in Tables 2 and 3 and plotted on Figures 1 and 2. The velocities used to determine the reflector depths are derived from shipboard Hamilton frame measurements. It should be pointed out that the coring program at Site 289 was continuous and that at Site 288 was discontinuous, and hence depth estimates at Site 289 are the more reliable.

The pattern of reflectors at the two sites is different. At Site 288, there are stronger reflectors in the upper part of the section than at Site 289. The strongest reflectors at Site 288 are at $0.22,0.50$, and $0.74 \mathrm{sec}$ (two-way travel time) at estimated subbottom depths of 172,415 , and 617 meters, respectively, while those at Site 289 are at $0.84,0.94$, and $1.00 \mathrm{sec}$ at 711,814 , and 873 meters, respectively. The greater energy return to the surface from higher levels at Site 288 is almost certainly attributable to the greater abundance of chert in the higher levels of that stratigraphic column.

\section{Porosity}

The plotted values represent core averages.

At Site 288 porosity decreases from just under $70 \%$ at the top to about $60 \%$ at 210 meters. At that level the porosity drops to $50 \%$ and remains fairly constant to about 650 meters. Below 650 meters values decrease rapidly, with large fluctuations, to about $20 \%$. The latter decrease coincides with the change from chalk to limestone.

At Site 289 the porosity decreases gradually from about $70 \%$ at the top of the sequence to about $40 \%$ at 1000 meters. Below this level, values decrease sharply, fluctuating between $10 \%$ and $40 \%$, increasing somewhat again below 1150 meters. These lower values are all in the chert-bearing lithified limestone interval. The large number of data points reflects the continuous coring at this site.

\section{Bulk Density}

The plotted values represent core averages. The bulk density trends compare closely with those of porosity.

At Site 288 the bulk density increases from 1.6 at the top to just under 1.7 at 210 meters. At this level there is a 


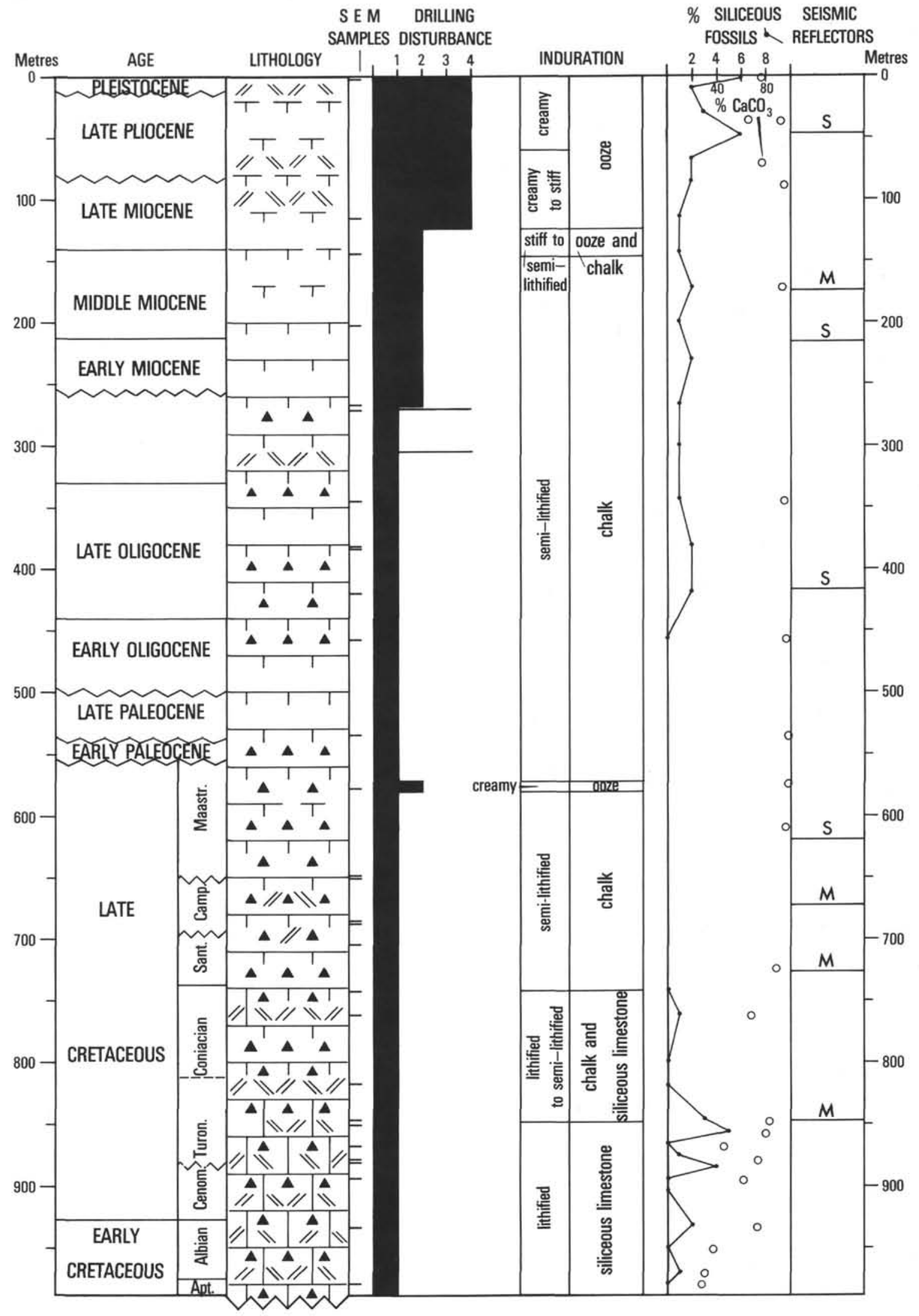

Figure 1. Site 288, stratigraphic column and plots of physical properties. 
RELATIONSHIPS BETWEEN DIAGENESIS AND PHYSICAL PROPERTIES OF BIOGENIC SEDIMENTS

POROSITY (\%) BULK DENSITY $\left(\mathrm{g} / \mathrm{cm}^{3}\right)$

SONIC VELOCITY (km/sec) (horizontal component)

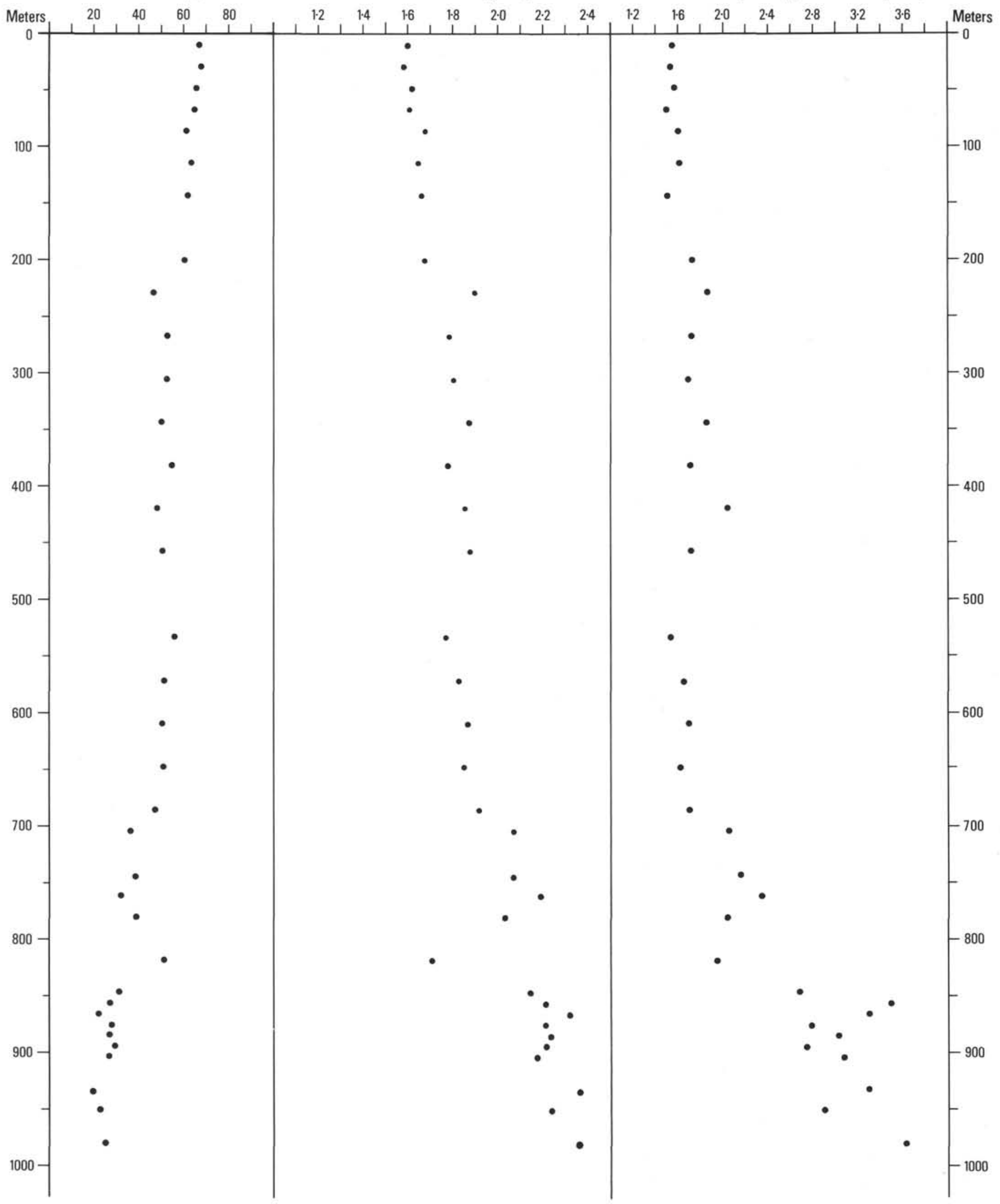

Figure 1. (Continued). 


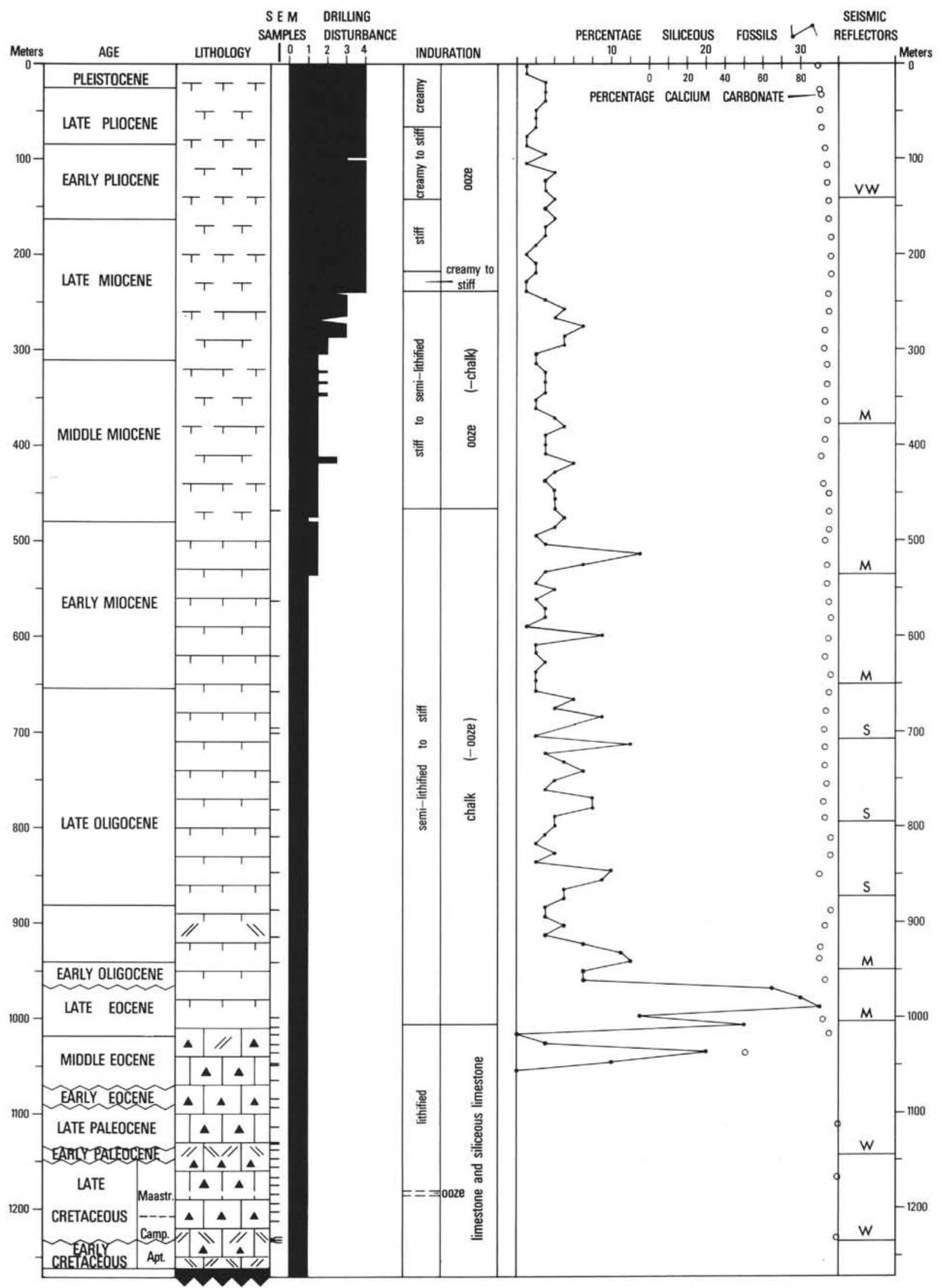

Figure 2. Site 289, stratigraphic column and plots of physical properties. 


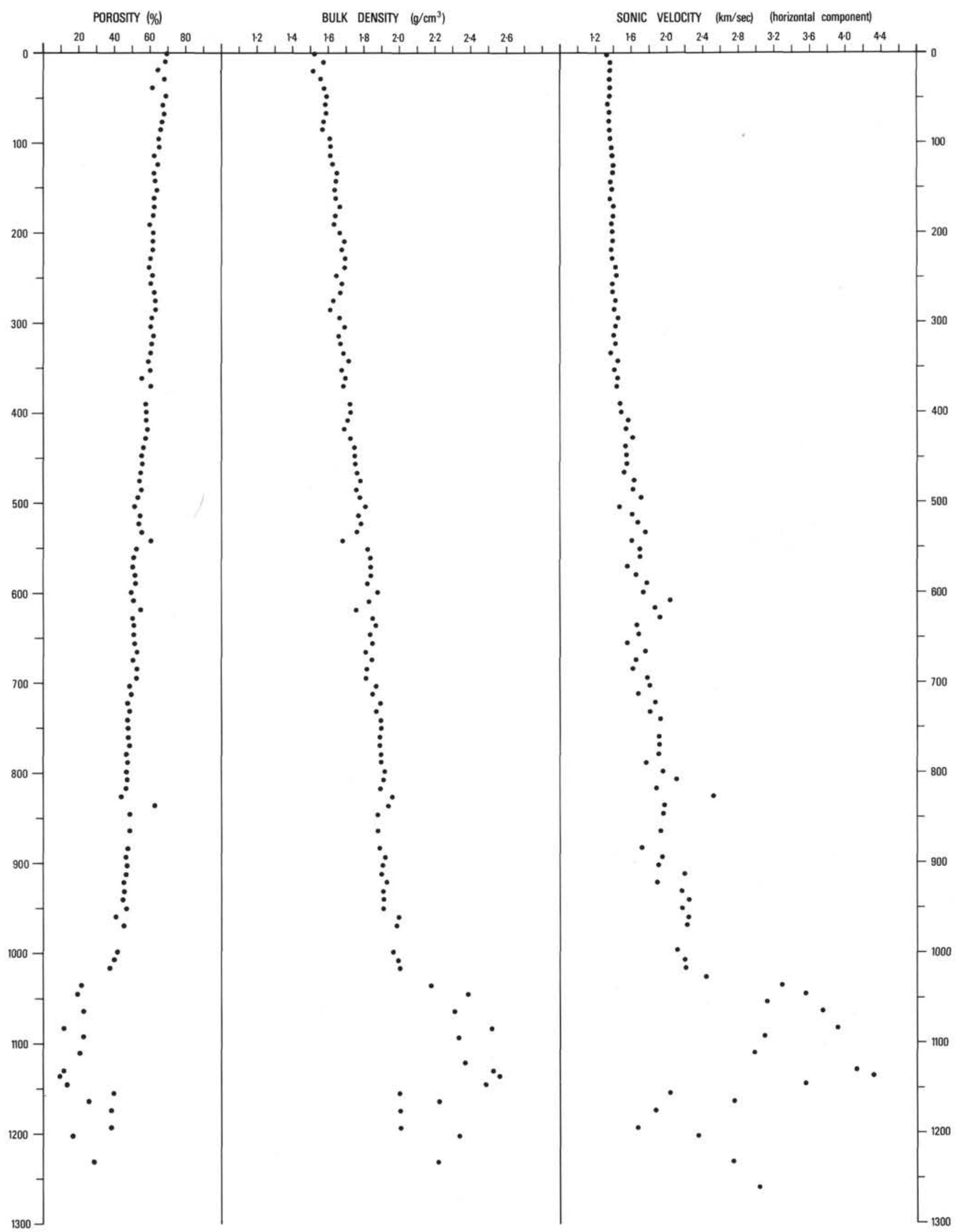

Figure 2. (Continued). 
TABLE 1

Bulk X-Ray Data, Sites 288, and 289

\begin{tabular}{|c|c|c|c|c|c|c|c|c|c|c|c|c|c|c|c|c|c|c|}
\hline $\begin{array}{l}\text { Sample Depth } \\
\text { Below Sea } \\
\text { Floor (m) }\end{array}$ & Diff. & Amor. & Calc. & Dolo. & Quar. & Cris. & $\mathrm{K}-\mathrm{Fe}$. & Plag. & Mica & Chlo. & Mont. & Paly. & Trid. & Clin. & Pyri. & Bari. & Sepi. & Augi. \\
\hline \multicolumn{19}{|l|}{ Hole 288} \\
\hline 2.70 & 57.6 & 31.5 & 97.5 & & 0.8 & & & 1.7 & & & & & & & & & & - \\
\hline 16.40 & 77.9 & 63.6 & 83.7 & & 0.5 & & & 12.0 & & & & & & & & & & 3.7 \\
\hline 72.20 & 50.0 & 19.2 & 97.9 & & 0.5 & & & 1.6 & & & & & & & & & & - \\
\hline 88.70 & 43.2 & 8.4 & 100.0 & & - & & & - & & & & & & & & & & \\
\hline \multicolumn{19}{|l|}{ Hole 288A } \\
\hline 457.80 & 42.6 & 7.4 & 100.0 & - & - & - & - & - & - & & - & - & - & - & & - & & \\
\hline 535.10 & 41.9 & 6.3 & 100.0 & - & - & - & - & - & - & & - & - & - & - & & - & & \\
\hline 535.90 & 44.3 & 10.2 & 100.0 & - & - & - & - & - & - & & - & - & - & - & & - & & \\
\hline 578.10 & 40.3 & 3.7 & 100.0 & - & - & - & - & - & - & & - & - & - & - & & - & & \\
\hline 579.30 & 39.3 & 2.1 & 100.0 & - & - & - & - & - & - & & - & - & - & - & & - & & \\
\hline 609.90 & 38.8 & 1.3 & 100.0 & - & - & - & - & - & - & & - & - & - & - & & - & & \\
\hline 649.40 & 81.4 & 48.0 & 22.3 & 2.3 & 5.9 & - & - & - & 5.5 & & 2.6 & 60.1 & - & 1.2 & & - & & \\
\hline 762.00 & 73.8 & 53.2 & 55.7 & - & 2.9 & - & - & 10.3 & - & & 4.0 & 4.3 & - & 19.5 & & 3.3 & & \\
\hline 762.00 & 48.7 & 18.1 & 88.4 & - & 10.0 & - & - & - & - & & - & - & - & - & & 1.6 & & \\
\hline 762.40 & 79.8 & 55.6 & 2.7 & - & 4.5 & - & - & 16.7 & 3.9 & & 15.0 & 13.7 & - & 35.0 & & 8.5 & & \\
\hline 850.80 & 79.4 & 65.0 & 80.2 & - & 11.2 & 5.8 & - & - & - & & - & - & 1.5 & - & & 1.3 & & \\
\hline 858.10 & 63.7 & 37.6 & 69.9 & - & 0.2 & - & - & 4.1 & - & & 3.9 & - & - & 17.2 & & 4.7 & & \\
\hline 876.70 & 56.7 & 9.4 & 54.2 & - & 13.9 & 22.8 & - & - & - & & 1.8 & - & 4.8 & - & & 2.5 & & \\
\hline 884.80 & 46.4 & 16.1 & 72.3 & - & 25.6 & - & - & - & - & & - & - & - & - & & 2.1 & & \\
\hline 895.00 & 47.8 & 16.8 & 79.0 & - & 17.0 & - & - & - & - & & 1.4 & - & - & - & & 2.6 & & \\
\hline 913.60 & 56.3 & 24.4 & 53.8 & - & 31.8 & 10.3 & - & 1.3 & - & & - & - & 2.1 & 0.8 & & - & & \\
\hline 934.20 & 44.9 & 14.2 & 67.5 & - & 30.1 & - & - & - & - & & - & - & - & - & & 2.4 & & \\
\hline 952.30 & 57.5 & 12.8 & 49.2 & - & 21.3 & 22.5 & - & - & - & & - & - & 5.5 & - & & 1.6 & & \\
\hline 971.10 & 57.0 & 13.9 & 32.2 & - & 37.5 & 28.0 & - & 1.1 & - & & - & - & - & 1.2 & & - & & \\
\hline 980.50 & 57.6 & 27.0 & 38.2 & - & 41.7 & 10.4 & 3.7 & 1.8 & 0.9 & & 2.2 & - & - & 1.0 & & - & & \\
\hline \multicolumn{19}{|l|}{ Site 289} \\
\hline 0.70 & 49.1 & 18.0 & 99.1 & & 0.9 & - & - & - & - & - & - & - & _- & - & - & - & - & \\
\hline 67.10 & 45.8 & 12.6 & 99.7 & & 0.3 & - & - & - & - & - & - & - & - & - & - & - & - & \\
\hline 144.40 & 44.3 & 10.2 & 100.0 & & - & - & - & - & - & - & - & - & - & - & - & - & - & \\
\hline 182.60 & 42.1 & 6.6 & 100.0 & & - & - & - & - & - & - & - & - & - & - & - & - & - & \\
\hline 260.20 & 43.3 & 8.5 & 100.0 & & - & - & - & - & - & - & - & - & - & - & - & - & - & \\
\hline 336.20 & 42.6 & 7.4 & 100.0 & & - & - & - & - & - & - & - & - & - & - & - & - & - & \\
\hline 374.10 & 44.2 & 10.0 & 100.0 & & - & - & - & - & - & - & - & - & - & - & - & - & - & \\
\hline 450.00 & 42.1 & 6.6 & 100.0 & & - & - & - & - & - & - & - & - & - & - & - & - & - & \\
\hline 488.90 & 43.3 & 8.5 & 100.0 & & - & - & - & - & - & - & - & - & - & - & - & - & - & \\
\hline 564.30 & 43.5 & 8.9 & 100.0 & & - & - & - & - & - & - & - & - & - & - & - & - & - & \\
\hline 602.00 & 42.6 & 7.4 & 100.0 & & - & - & - & - & - & - & - & - & - & - & - & - & - & \\
\hline 678.30 & 44.7 & 10.8 & 100.0 & & - & - & - & - & - & - & - & - & - & - & - & - & - & \\
\hline 716.30 & 43.4 & 8.7 & 100.0 & & - & - & - & - & - & - & - & - & - & - & - & - & - & \\
\hline 754.40 & 44.7 & 10.8 & 100.0 & & - & - & - & - & - & - & - & - & - & - & - & - & - & \\
\hline 790.20 & 46.6 & 13.9 & 100.0 & & - & - & - & - & - & - & - & - & - & - & - & - & - & \\
\hline 829.90 & 41.8 & 6.1 & 100.0 & & - & - & - & - & - & - & - & - & - & - & - & - & - & \\
\hline 887.30 & 57.5 & 30.8 & 93.0 & & - & - & - & 6.3 & - & - & - & - & - & - & 0.6 & - & - & \\
\hline 915.80 & 60.6 & 35.9 & 95.8 & & - & - & - & 2.9 & - & - & 1.3 & - & - & - & - & - & - & \\
\hline 925.80 & $\begin{array}{l}00.0 \\
46.4\end{array}$ & 13.5 & $\begin{array}{r}9.0 \\
100.0\end{array}$ & & - & - & - & - & - & - & - & - & - & - & - & - & - & \\
\hline 950.80 & 59.1 & 34.0 & 100.0 & & - & - & - & - & - & - & - & - & - & - & - & - & - & \\
\hline 960.40 & 44.1 & 9.8 & 100.0 & & - & - & - & - & - & - & - & - & - & - & - & - & - & \\
\hline 1001.60 & 43.7 & 9.2 & 100.0 & & - & - & - & - & - & - & - & - & - & - & - & - & - & \\
\hline 1036.80 & 61.3 & 23.2 & 70.8 & & 5.3 & 16.3 & - & - & - & - & - & - & 6.3 & - & - & 1.4 & 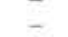 & \\
\hline 1065.20 & 39.6 & 2.6 & 100.0 & & - & - & - & - & - & - & - & - & - & - & - & - & - & \\
\hline 1112.30 & 39.8 & 2.9 & 100.0 & & - & - & - & - & - & - & - & - & - & - & - & - & - & \\
\hline 1138.30 & 70.6 & 48.2 & 55.8 & & 1.2 & - & 1.6 & - & - & 1.6 & 3.7 & - & - & 15.0 & - & - & 21.2 & \\
\hline 1194.40 & 39.2 & 1.9 & 100.0 & & - & - & - & - & - & - & - & - & - & - & - & - & - & \\
\hline 1230.50 & 72.1 & 39.3 & 47.6 & & 6.5 & - & 3.6 & - & 5.4 & 0.6 & 1.3 & 35.1 & - & - & - & - & - & \\
\hline 1231.60 & 80.4 & 33.5 & - & & 11.3 & - & 5.7 & - & 4.8 & 0.6 & 2.3 & 75.3 & - & - & - & - & - & \\
\hline 1233.60 & 49.1 & 14.5 & 89.7 & & 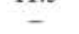 & - & - & - & - & - & 1.6 & 3.9 & - & 1.5 & - & 3.2 & - & \\
\hline 1259.50 & 39.3 & 2.1 & 100.0 & & - & - & - & - & - & - & - & - & - & - & - & - & - & \\
\hline 1261.50 & 79.1 & 52.4 & - & & 8.7 & - & 59.6 & - & 3.1 & - & 28.7 & - & - & - & - & - & - & \\
\hline 1261.80 & 87.4 & 69.7 & - & & 7.2 & - & 41.7 & - & 8.6 & - & 42.5 & - & - & - & - & - & - & \\
\hline 1262.30 & 38.6 & 1.0 & 94.9 & & 4.1 & 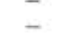 & 41.1 & $=$ & 1.0 & - & - & - & - & - & - & - & - & \\
\hline
\end{tabular}


TABLE 2

Estimated Depths to Seismic Reflectors at Site 288

\begin{tabular}{cccc}
\hline $\begin{array}{c}\text { Reflector } \\
\text { Intensity }\end{array}$ & $\begin{array}{c}\text { Reflector Depth } \\
\text { (2-way Travel Time } \\
\text { Below Sea Floor) }\end{array}$ & $\begin{array}{c}\text { Interval Velocity } \\
\text { to Next } \\
\text { Reflector (m/sec) }\end{array}$ & $\begin{array}{c}\text { Estimated } \\
\text { Depth to } \\
\text { Reflector (m) }\end{array}$ \\
\hline S & 0.0 & 1540 & 0 \\
M & 0.06 & 1580 & 46 \\
S & 0.22 & 1730 & 172 \\
M & 0.27 & 1740 & 215 \\
S & 0.50 & 1690 & 415 \\
S & 0.74 & 1630 & 617 \\
M & 0.81 & 2090 & 674 \\
M & 0.86 & 2290 & 726 \\
M & 0.97 & 2290 & 847 \\
\hline
\end{tabular}

${ }^{\text {a }} \mathrm{S}=$ strong, $\mathrm{M}=$ moderate.

TABLE 3

Estimated Depths to Seismic Reflectors at Site 289

\begin{tabular}{cccc}
\hline $\begin{array}{c}\text { Reflector } \\
\text { Intensity }\end{array}$ & $\begin{array}{c}\text { Reflector Depth } \\
\text { (2-way Travel Time } \\
\text { Below Sea Floor) }\end{array}$ & $\begin{array}{c}\text { Interval Velocity } \\
\text { to Next } \\
\text { Reflector (m/sec) }\end{array}$ & $\begin{array}{c}\text { Estimated } \\
\text { Depth to } \\
\text { Reflector (m) }\end{array}$ \\
\hline S & 0.0 & 1550 & 0 \\
VW & 0.18 & 1580 & 140 \\
M & 0.48 & 1750 & 377 \\
M & 0.66 & 1950 & 535 \\
M & 0.78 & 1970 & 652 \\
S & 0.84 & 2050 & 711 \\
S & 0.96 & 1970 & 814 \\
S & 1.00 & 2200 & 873 \\
M & 1.07 & 2150 & 951 \\
M & 1.12 & 4000 & 1004 \\
W & 1.19 & 2500 & 1144 \\
W & 1.26 & (?Basalt) & 1232 \\
\hline
\end{tabular}

${ }^{\text {a }} \mathrm{S}=$ strong, $\mathrm{M}=$ moderate, $\mathrm{VW}=$ very weak.

jump to 1.9. Between 210 and 600 meters, values fluctuate between 1.9 and somewhat less than 1.8. Below 650 meters values increase, with fluctuations, to almost 2.4 .

At Site 289 values increase gradually from just over 1.5 at the top to 2.0 at about 1000 meters. Below that level values increase rapidly, with large fluctuations, to almost 2.6, decreasing somewhat again below 1150 meters.

\section{Sonic Velocities}

Onboard the ship horizontal and vertical sonic velocity components were measured on sediment cubes, cut from the core. Differences between the two components were detected, especially in the more indurated parts of the sediment sequence. Investigations into the causes of this anisotropy did not form part of the present study, not because of lack of interest, but because of time involved. This matter will be pursued in the future. For the present study only the core averages of the horizontal velocity component have been plotted, as this is the component normally recorded during shipboard measurements. At both sites there is a close parallelism between the sonic velocity trends and those of porosity and bulk density.

At Site 288 the sonic velocity is between 1.5 and 1.6 $\mathrm{km} / \mathrm{sec}$ near the surface. It remains fairly constant, fluctuating between these two values, to about 175 meters.
Between 150 and 200 meters there is a stop in the velocity, and from 200 to about 500 meters, values fluctuate between 1.7 and 2.1. The value of 2.1 at 420 meters is almost rigid. Below 500 meters values drop to under 1.6, after which they gradually increase to 1.7 at about 700 meters. Below that level there is a jump in sonic velocity to over 2.0. From 700 to about 830 meters values fluctuate between 1.9 and 2.4. Below 830 meters there is another jump, to over 2.6. Between 830 meters and the bottom of the hole values fluctuate widely between 2.0 and 3.6.

At Site 289 values decrease regularly from just under 1.6 at the top to about 2.4 at 1000 meters. Below this level values increase rapidly with large fluctuations, to about 4.5. Below 1150 meters there is a slight decrease, again with large fluctuation.

\section{SCANNING ELECTRON MICROSCOPIC FEATURES OF THE SEDIMENTS}

\section{Introduction}

At Site 288, the highest sample studied comes from only 0.9 meters below the sediment-water interface. At Site 289 , the highest sample studied was taken at 468.9 meters, at about the level where ooze (-chalk) changes to chalk (-ooze). Apart from the unindurated ooze samples, freshly broken surfaces only were studied. 


\section{Site $\mathbf{2 8 8}$}

The sediments near the top of the hole consist of whole tests and broken fragments of calcareous and siliceous organisms (Figure 3). Fragmentation can take place in the water column during settling (see Lisitzin, 1971, fig. 127), and, near the sediment-water interface, by infaunal activity.

During the first stages of lithification water expulsion is the main process. The sediment becomes stiff and crumbly when a grain-supporting framework is established (Packham and van der Lingen, 1973). Further diagenesis takes place through a complicated process of dissolution and reprecipitation (see earlier review of progressive carbonate diagenesis studies).

Through dissolution of foraminifera and easily dissolvable coccoliths, micritic, anhedral particles are produced. Such particles are called "micarb" by DSDP. These micritic particles and the remaining fossil tests form the substrate ("nucleation sites," "seed crystals") for calcite precipitation. Dissolution and reprecipitation are taking place simultaneously (Figures 4 and 5, 202.6 meters). Precipitation starts in the central parts of coccolith placoliths and on micarb particles. Welding of individual particles start at the boundary ooze-chalk (Figure 4).

Discoasters are particularly susceptible to calcite overgrowth (Figures 4 and 6). This overgrowth must have started before or soon after burial. Seldom have discoasters without overgrowth been observed in DSDP cores. This phenomenon has been explained by the fact that discoasters are single crystals, and as such are ideal "seed crystals" (Wise and Kelts, 1972; Matter, 1974). Adelseck et al. (1973) reproduced discoaster overgrowth experimentally. Figure 6 shows two stages of discoaster overgrowth. The new calcite envelops some coccoliths, thus contributing to the lithification (welding) process.

The first chert nodule occurs at 267.3 meters. This nodule consists of a fine-grained matrix in which irregular patches of coarser silica occur (Figure 7). The fine-grained matrix consists of chalcedony crystals (Figure 8), while the coarser patches are made up of interlocking quartz crystals (Figure 9).

The next step in recrystallization is the bridging of the space between the proximal and distal shields of coccolith placoliths (Figure 10, $271.4 \mathrm{~m}$ ).

Dissolution and reprecipitation increases downwards. Euhedral calcite crystals, most of them formed by overgrowth of fossil fragments, increase in size. Some of these crystals show pits, resembling negative crystals (Figure 11, $382.0 \mathrm{~m}$ ). It may well be that these pits are typical for calcite crystals enclosing fossil fragments.

Compaction by crushing of fossil tests seems to play a minor role only. Most foraminifera seem to remain intact (Figure 12, 420.1 m).

At 457.6 meters, most micarb particles have become subhedral, showing some crystal faces (Figures 13 and 14). The central part of some coccoliths become filled with new calcite, while others develop angular euhedral overgrowths along their circumference (Figure 14). Pore space decreases, but average porosity in this interval is still $50 \%$. Figure 14 shows some clusters of radiating subhedral calcite crystals. A similar cluster is also visible in Figure 11. They are the (partly overgrown?) nan- nofossil Sphenolithus moriformis (A.R. Edwards, personal communication).

The outline of coccoliths becomes more angular downwards (Figure 15, 535.3 m). The size of euhedral calcite and the degree of welding also increases.

At about the Cretaceous-Tertiary boundary $(550 \mathrm{~m})$ both the bulk density and the sonic velocity decrease somewhat. The corresponding increase in porosity is less pronounced. Not far below this boundary there is a temporary reversal in induration (to ooze). Figures 16 and 17 are SEM photographs of this ooze horizon. The particles, however, do not show a much lower diagenetic stage. For instance, the space between the distal and proximal shields of coccolith placoliths is filled in with secondary calcite. Micritic micarb particles and the surfaces of foraminifera have euhedral calcite overgrowths. There is, however, no sign of welding. It is difficult to explain this phenomenon. Maybe at this level the balance between solution and reprecipitation was more in favor of solution than in the horizons directly above and below. On the other hand, it may be a reflection of a change in paleooceanographic chemistry. Supporting this possibility is the fact that a similar reversal is observed at Site 289 , at about the same age level, though at a much greater depth.

At 650 meters diagenesis has increased again. Particles are welded together by overgrowth calcite (Figures 18 and 19). The matrix locally exists of a fairly tight packing of subhedral to euhedral micarb particles (Figure 19). Coccoliths consist of angular "keystone plates" (Figure 18). This angularity seems to be characteristic of Mesozoic coccolith forms (A.R. Edwards, personal communication). It is not always easy to distinguish between primary (taxonomic) angularity and secondary overgrowth. Only features like irregular size of the plates and interpenetration of calcite crystals can establish secondary changes. Disintegration of angular coccoliths produces abundant rhombic particles which might be mistaken for authigenic dolomite rhombs (Figure 18). This is all the more relevant as at this very level real dolomite rhombs do occur, large ones (Figure 20) and small ones (Figure 21). The presence of dolomite is confirmed by the bulk X-ray data (Table 1).

There is a substantial change in the overall composition of the sediment at this level. Above 650 meters calcium carbonate percentages are between $90 \%$ and $100 \%$. The bulk X-ray diffraction data indicate $100 \%$ calcite for the crystalline fraction. Below this level, the calcium carbonate percentage decreases, and the bulk $\mathrm{X}$-ray data indicate the presence of dolomite, quartz, cristobalite, plagioclase, mica, montmorillonite, palygorskite, tridymite, clinoptilolite, and barite, in varying quantities. This clearly indicates mixing of biogenic sediment with volcanic debris, most of which has subsequently been altered. It is quite likely that the magnesium for the dolomite has been derived from the volcanic material.

The presence of a substantial nonbiogenic component locally gives the sediment a "dirty" look (Figure 22, $705.5 \mathrm{~m}$, and Figure 23, $818.3 \mathrm{~m}$ ) and diagenetic changes are more difficult to observe.

Below 700 meters there is a further decrease in porosity and increase in bulk density and sonic velocity. The sediment gradually changes from a chalk to limestone. 


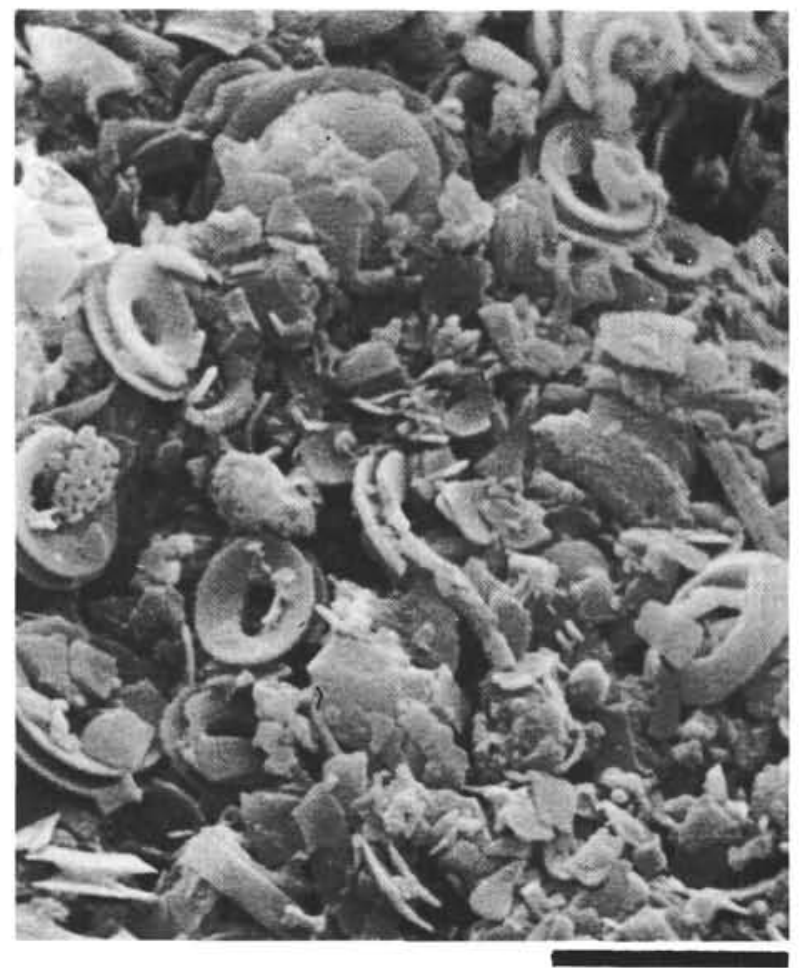

Figure 3. Site 288, 0.91 meters, Pleistocene, foramnanno ooze, porosity $(15.94 \mathrm{~m}$ ) $69 \%$, scale bar $12 \mu$; unconsolidated sediment near the sediment-water interface, consisting of nannofossils and abundant broken fragments of nannofossils and foraminifera.

The limestone is for the greater part silicified. The matrix can become quite dense, and the sediment shows imprints of coccoliths (Figure 24, $743.2 \mathrm{~m}$ ).

Figure $23(818.3 \mathrm{~m})$ is from a sample with a substantial nonbiogenic component. Silica spherules are present (Figures 25 and 26). Both cristobalite and tridymite were recorded in a sample not far below this one (Table 1). This seems to support the theory of cristobalite formation by Lancelot (1973), mentioned earlier.

The next two samples studied are close together $(847.0$ and $850.8 \mathrm{~m}$ ). The coccoliths are very angular (Figure $27,847.0 \mathrm{~m})$. The growth of euhedral calcite crystals inside foram chambers has advanced further (Figure 28). Figure 29 shows a foram chamber completely filled with a single crystal. It is very difficult to determine the nature of a crystal from its shape only. Analysis by EDAX would be required to establish its identity (equipment not available to the authors). Figure 27 shows a peculiar amorphous material, enveloping carbonate particles. The same feature can be seen on Figure 52 (Site 289, $886.2 \mathrm{~m}$ ). Figure 27 also shows some fine threads. Such threads have been observed in some samples, and are probably fungi, grown in the sample after collection. The enveloping material might also be a fungus growth. If not, it could be a form of amorphous silica.

Silica diagenesis is well shown in Figures 30 and 31 $(850.8 \mathrm{~m})$. The first shows a ghost of either a radiolarian or a foraminiferal chamber, filled with silica. The groundmass is also silicified, embedding coccoliths.

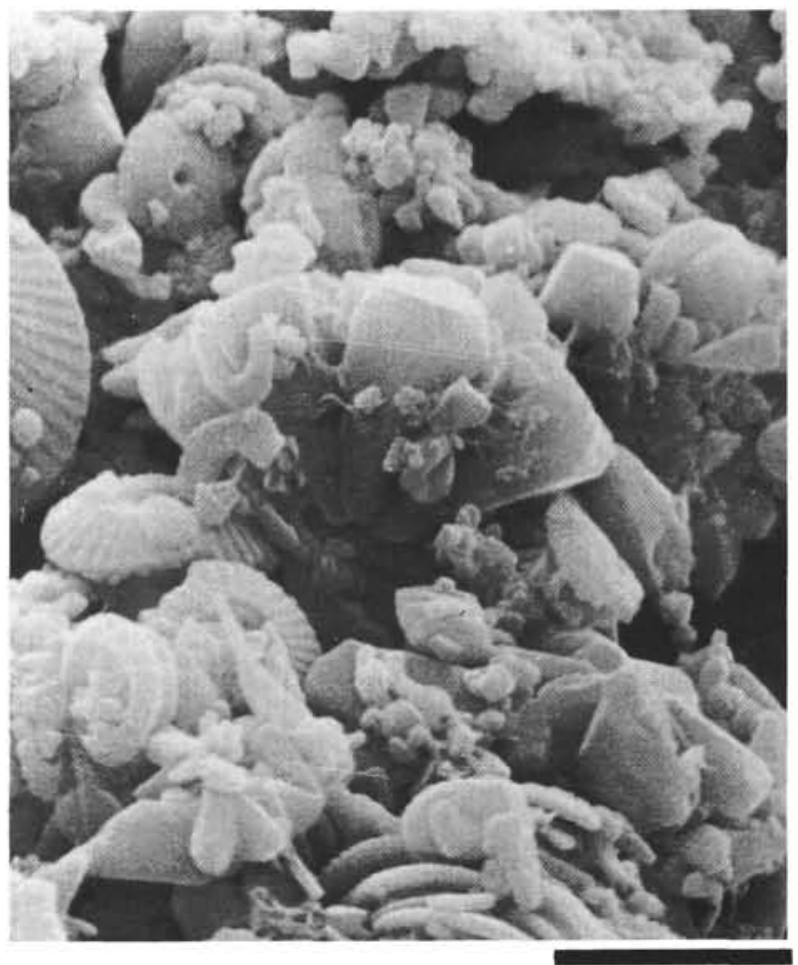

Figure 4. Site 288, 202.6 meters, middle Miocene, nanno chalk, porosity $(202.2 \mathrm{~m}) 60 \%$, scale bar $16 \mu$; discoasters have completely been overgrown by secondary calcite, showing euhedral crystal faces; the secondary calcite has welded fossil fragments together; welding can also be seen in other parts of the picture; note corroded coccoliths.

Figure 31 shows silica spherules, together with a clinoptilolite crystal. This kind of paragenesis has been discussed earlier. The silica spherules are of the "sugary surface" type. The bulk X-ray data indicate the presence of cristobalite and tridymite, but no clinoptilolite. However, clinoptilolite is recorded in the 2 to $20 \mu \mathrm{m}$ fraction.

Figure $32(867.8 \mathrm{~m})$ shows advanced recrystallization of coccolith cement. Welding of particles is well advanced. Chert nodules from the same level show a smooth breakage surface (Figure 33 ).

Because of the substantial amount of silicification in this lowermost interval, progressive changes in carbonate diagenesis are difficult to observe. Porosity has by now decreased to between $20 \%$ and $30 \%$, while bulk density and sonic velocity have increased substantially.

Figure $34(879.5 \mathrm{~m})$ shows the boundary between a chert nodule and (silicified) chalk. The chalk shows faint and smoothed outlines of coccoliths (Figure 35). The smoothness is probably due to silica coating and not to dissolution. It is quite common in samples from silicified carbonate rock to observe a coating of carbonate particles with a substance looking like icing sugar. The fracture surface of the chert is smooth, showing some fracture lines (Figure 36 ). The only possible organic remains (or ghosts) are spherical objects (Figure 36). These may represent recrystallized radiolarians. 


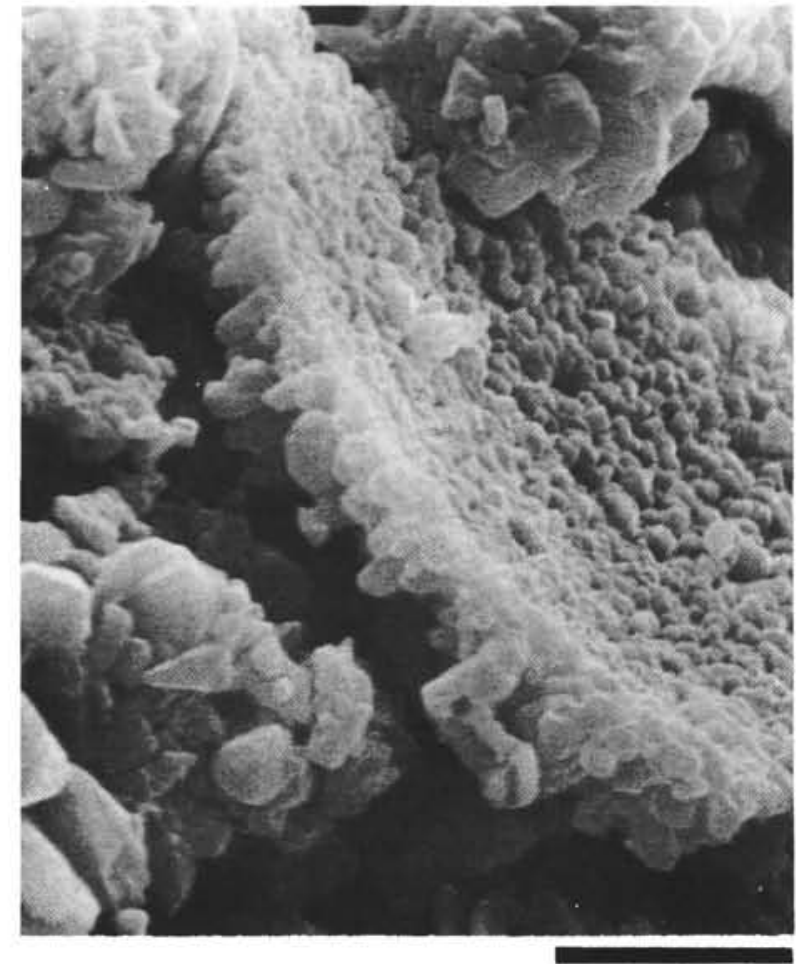

Figure 5. Site 288, 202.6 meters, middle Miocene, nanno chalk, porosity $(202.2 \mathrm{~m}) 60 \%$, scale bar $16 \mu$; fragment of a foraminifera, showing granular surface due to dissolution.

Thin sections of silicified limestones often show spherical objects, filled with chalcedony or microquartz (e.g., Lancelot, 1973). Such spheres are called "silicospheres" (not to be confused with the silica spherules, which are of an entirely different order of magnitude). They generally are silicified radiolarian molds or single foraminiferal chambers. Figure $37(894.5 \mathrm{~m})$ shows a roughly spherical body consisting of platy silica, probably chalcedony. This most likely is a silicosphere. The sediment around this silicosphere shows the usual angular coccoliths.

Figures 38 to 40 are from the lowest sample studied (979.9 m). Figure 38 is a good example of a silicosphere, while Figure 39 shows the faint outline of a silicified foraminifera. Figure 40 shows a remarkably well preserved coccolith in a silica matrix.

\section{Site 289}

At Site 289, the overall sediment thickness is much greater than at Site 288. The Tertiary is about twice as thick, while the Cretaceous is about four times thinner than at Site 288. Another important difference between the two sites is the absence of chert and volcanic debris from the late Eocene onwards at Site 289. For further discussion, see Site 289 Site Report. This has the advantage that carbonate diagenesis in the top thousand meters at Site 289 can be studied without the interference of silica or volcanic debris.

Where appropriate, the scanning electron photomicrographs of Site 289 will be compared with those from Site 288.

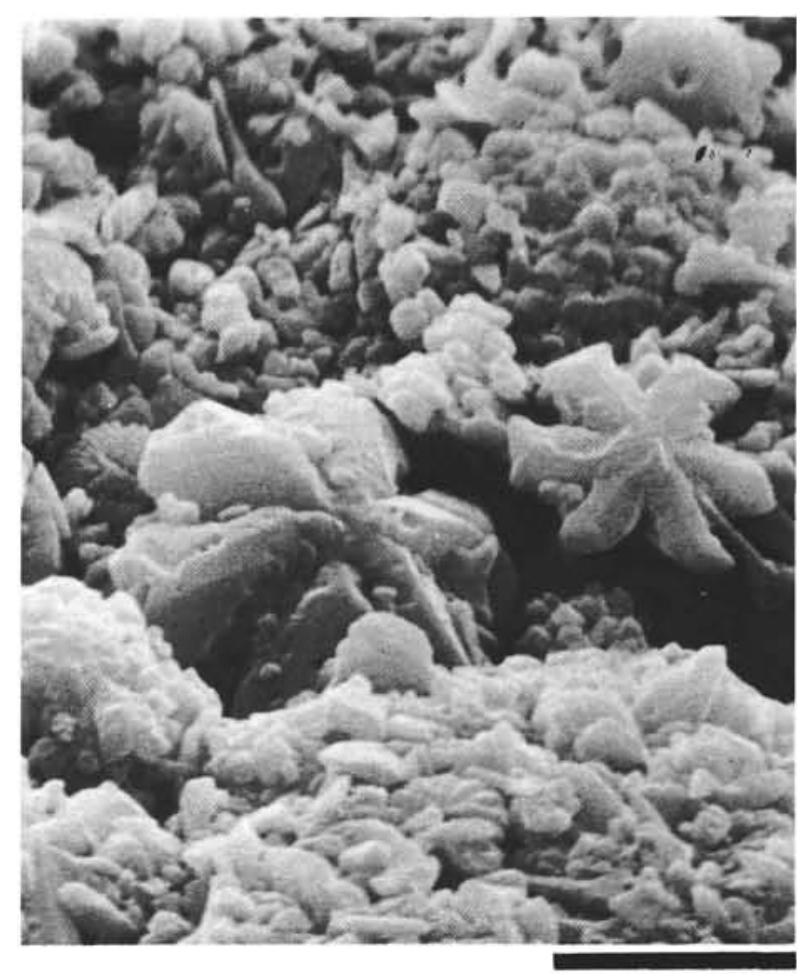

Figure 6. Site 288, 202.6 meters, middle Miocene, nanno chalk, porosity $(202.2 \mathrm{~m}) 60 \%$, scale bar $16 \mu$; discoasters in the center of the picture show two stages of calcite overgrowth, the right-hand side one being least overgrown; note the abundance of micarb particles, partly overgrown with new calcite.

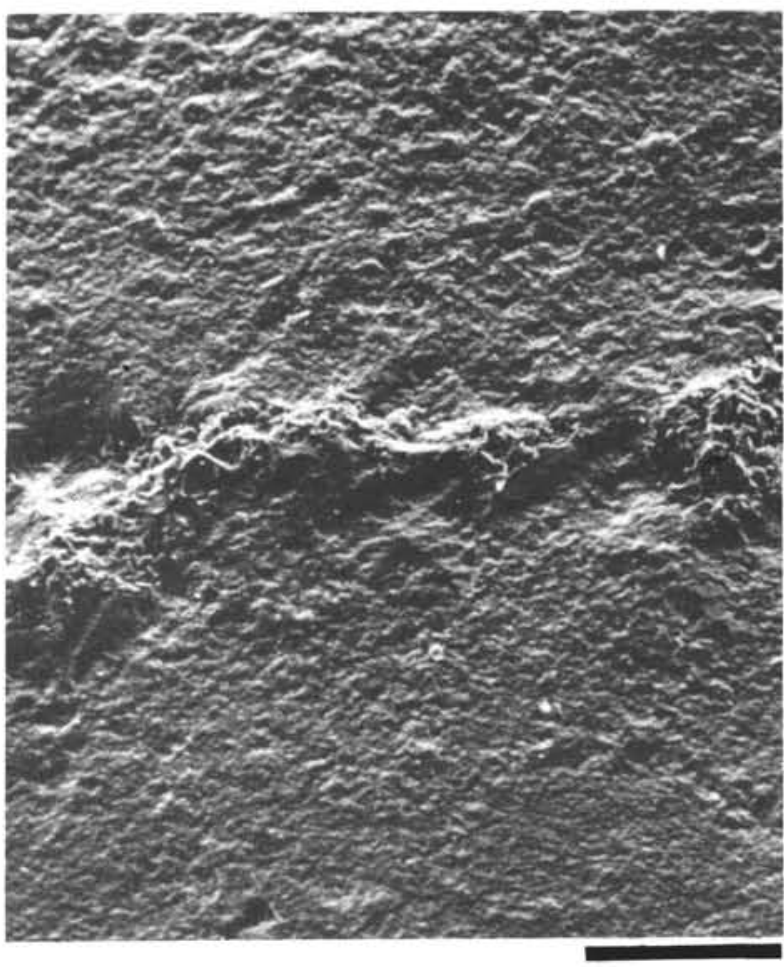

Figure 7. Site 288, 267.3 meters, late Oligocene, chert nodule in nanno chalk, scale bar $300 \mu$; dense chert with irregular coarser crystalline patches. 


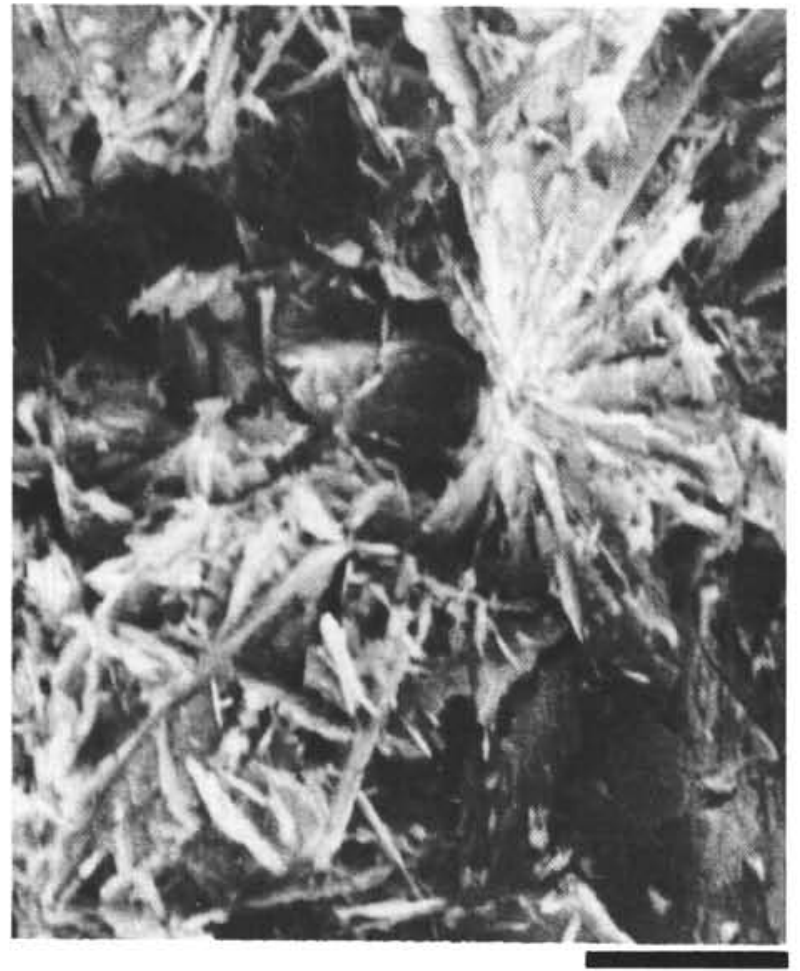

Figure 8. Site 288, detail of Figure 7, scale bar $6 \mu$, dense part of chert, showing chalcedony crystallites.

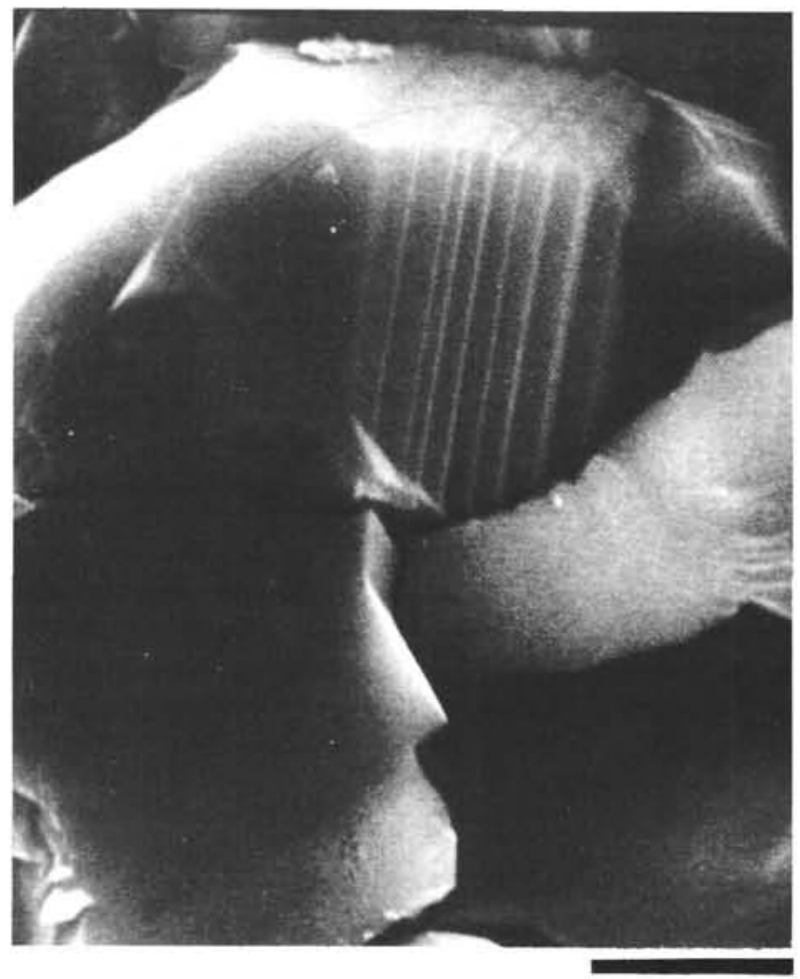

Figure 9. Site 288, detail of Figure 7, scale bar $6 \mu$; interlocking quartz crystals in coarser crystalline patch of chert.

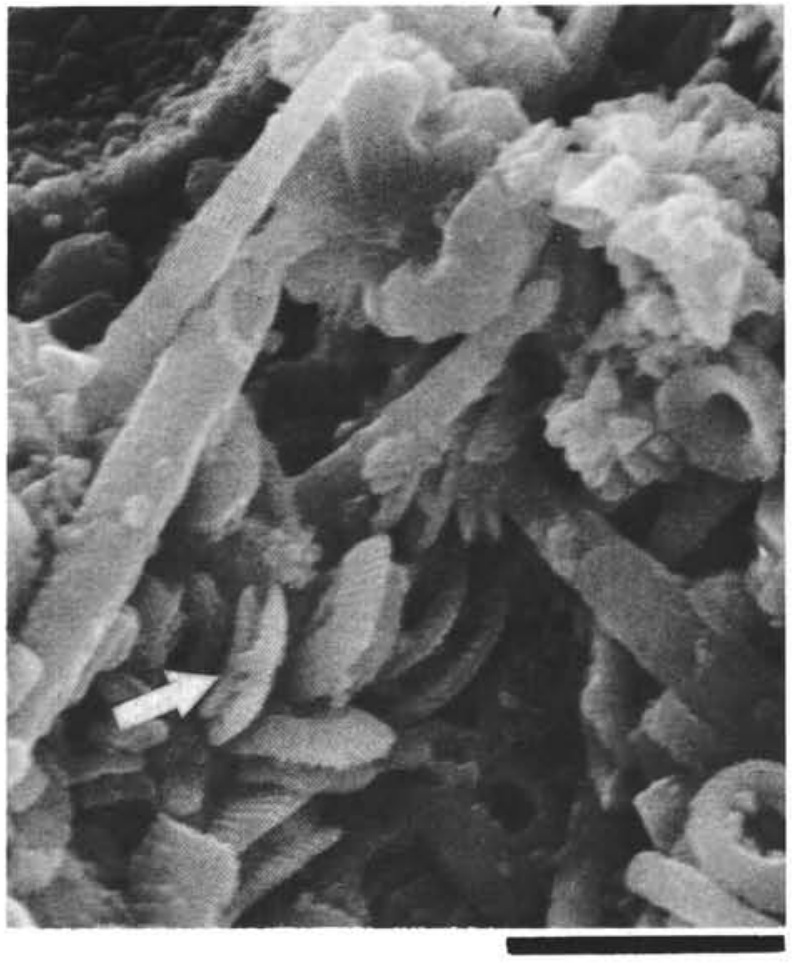

Figure 10. Site 288, 271.4 meters, early Miocene, nanno chalk, porosity $(270.7 \mathrm{~m}) 53 \%$, scale bar $8 \mu$; foraminiferal fragments, nannofossils, and calcareous spicules (foraminiferal spicules?); many particles are welded together; the space between proximal and distal shields of coccolith placoliths is partly bridged by secondary calcite (arrow); new calcite is growing in the central parts of coccoliths (lower right-hand corner).

The first sample studied $(468.9 \mathrm{~m})$ shows partly dissolved coccoliths, overgrown discoasters, and abundant anhedral micarb particles (Figure 41). These micarb particles clearly are derived from disintegrated nannofossils and foraminifera. The secondary calcite on discoasters has incorporated (and welded) some coccolith particles. Minor recrystallization has taken place in the central parts of coccoliths. A similar diagenetic stage at Site 288 is shown in Figures 4 to $6(202.6 \mathrm{~m})$.

More pronounced overgrowth and welding is shown in Figure 42 (562.4 m). At 620.4 meters, micarb particles start to show euhedral crystal faces due to overgrowth (Figures 43 and 44). Secondary calcite bridges the space between proximal and distal placolith shields (Figure 44). This phenomenon is even better shown in Figure 45 $(657.5 \mathrm{~m})$. Calcite growth in the central parts of coccolith placoliths has become more pronounced. A comparable diagenetic level at Site 288 is shown in Figure 13 (457.6 m).

Figures 46 and 47 show calcite needles. Similar needles also exist at Site 288 (Figure 10). Euhedral crystal faces and an imprint of a coccolith clearly indicate secondary overgrowth. This has obscured the 


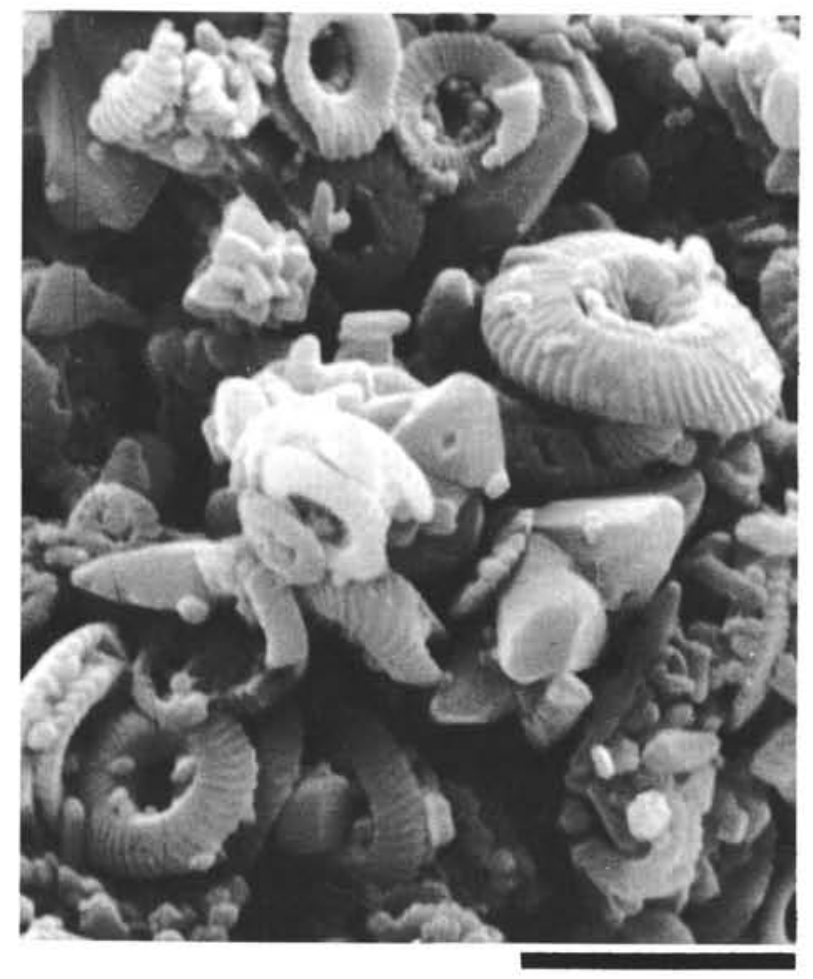

Figure 11. Site 288, 382.0 meters, late Oligocene, foram nanno chalk, porosity $(382.7 \mathrm{~m}) 55 \%$, scale bar $8 \mu$; coccoliths show corrosion and calcite precipitation; particles are welded together; large euhedral calcite crystals in the center /some having "negative crystals") are probably all overgrown fossil particles; radiating cluster of calcite crystals is the nannofossil Sphenolithus moriformis.

morphology of the needles. They may be either calcareous sponge spicules or foraminiferal spicules.

Figure 48 (704.8 $\mathrm{m})$ shows pronounced dissolution of coccoliths. One placolith shows secondary calcite growth in between shields. It seems that part of this secondary calcite has subsequently been dissolved as well. This has interesting consequences. We stated earlier that dissolution and reprecipitation take place simultaneously. The balance between the two processes apparently can change in time, and already precipitated calcite can get dissolved again.

Figure $49(752.1 \mathrm{~m})$ shows increased calcite overgrowth on coccoliths and micarb particles. At about 847.0 meters the coccoliths have developed an angular outline through the development of calcite crystal faces. If such coccoliths disintegrate, they produce "pseudodolomite" rhombs (Figure 50). A similar phenomenon was observed in Figure 18 of Site $288(650.0 \mathrm{~m})$. Figure 50 shows a "euhedral" discoaster, the center of which is strongly pitted. It is difficult to establish whether this pitting is primary (no secondary calcite deposited), or whether it is due to dissolution or to breakage. Figure 51 , from the same sample, shows euhedral calcite growth inside a foraminiferal chamber, and in the surrounding matrix. A comparable stage is shown in Figure 28 of Site $288(847.0 \mathrm{~m})$.

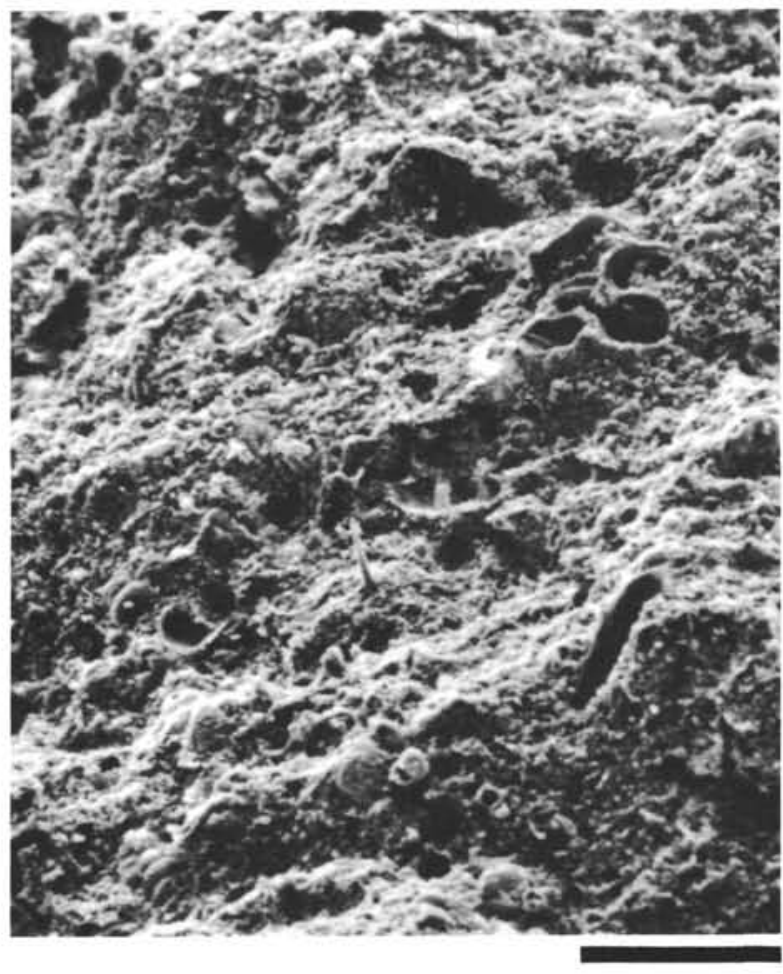

Figure 12. Site 288, 420.1 meters, late Oligocene, nanno chalk, porosity (420.2 m) 48\%, scale bar $160 \mu$; breakage surface showing uncrushed foraminifera.

Figure $52(886.2 \mathrm{~m})$ shows partly dissolved coccoliths as well as secondary calcite overgrowth on coccoliths. Abundant micritic subhedral grains can be seen. Larger grained euhedral calcite cement welds particles together. A radial calcite crystal aggregate, similar to those described from Figure 14 (Site 288, $457.6 \mathrm{~m}$ ), probably being the nannofossil Sphenolithus moriformis, is also present.

Figure $53(914.3 \mathrm{~m})$ can be directly compared with Figure $43(620.4 \mathrm{~m})$. Both show part of a radiolarian, partly covered with micritic particles. However, in Figure 53 the radiolarian test has been corroded more, and the micritic grains have obtained euhedral outlines through overgrowth.

At 941.2 meters, welding seems further advanced (Figure 54). Some coccoliths have obtained a smooth surface (either through solution or by coating with "icing sugar" silica). Some wisp-like bridging structures can be seen (see Figures 54 and 55) similar to those described by Packham and van der Lingen (1973, Plate 4 , fig. 4 and 5). The authors think that such bridging structures consist of silica. Though the first chert was observed somewhat lower in the sequence (at $1009 \mathrm{~m}$ ), some silica may already be present at this level. Smearslide estimates do indicate an increase in siliceous fossil content at about this level (Figure 2).

The next photomicrograph (Figure 56, 1009.1 m) is from a sample near the top of the limestone interval. At this level the first chert was observed. Euhedral overgrowth on foraminiferal fragments, coccoliths, and micarb particles is well advanced. 


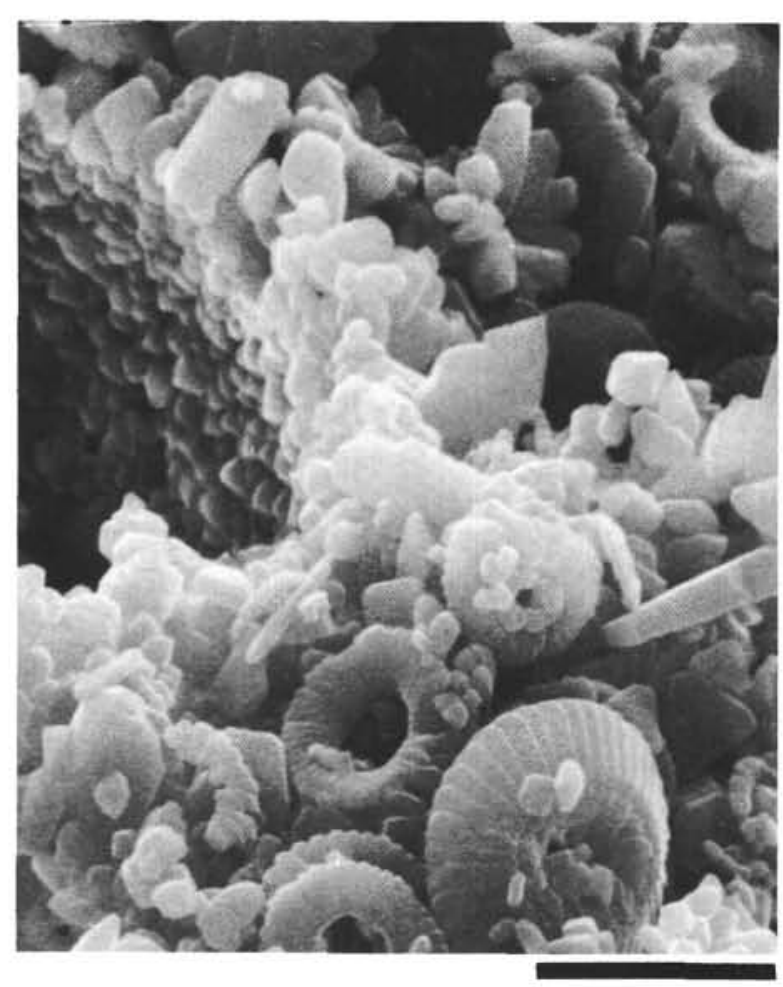

Figure 13. Site 288, 457.6 meters, early Oligocene, nanno chalk, porosity $(457.8 \mathrm{~m}) 52 \%$, scale bar $12 \mu$; coccoliths show extensive calcite recrystallization in their central parts and in between proximal and distal shields; most micarb particles have obtained euhedral outlines; the granular inner surface of the foraminiferal fragment starts to develop new calcite overgrowth.

Figure $57(1017.2 \mathrm{~m})$ shows a fairly tight packing of coccoliths, coccolith fragments, and micarb. The diagenetic stage seems somewhat less than at higher levels.

The next sample was taken just below the sudden decrease in porosity and increase in bulk density and sonic velocity. Welding has become very significant (Figure 58, 1027.1 m). The central area of some coccoliths has become filled "to overflowing" with euhedral calcite crystals. Overgrowth calcite crystals interpenetrate each other. The calcite crystals inside foraminiferal chambers have reached relatively large sizes (Figure 59).

Comparisons with Site 288 are virtually impossible, because of the presence of volcanic material and silica at that site. Figure 32 (Site $288,867.8 \mathrm{~m}$ ) probably depicts about the same diagenetic level.

Volcanic and altered volcanic material is present in the lower 200 meters of Site 289, though in far lower quantities than at Site 288. The bulk X-ray data indicate the presence of quartz, cristobalite, potash feldspar, mica, chlorite, montmorillonite, palygorskite, tridymite, clinoptilolite, barite, and sepiolite (Table 1). These minerals, in limited combinations, are irregularly distributed. In contrast to the lower part of Site 288, pure

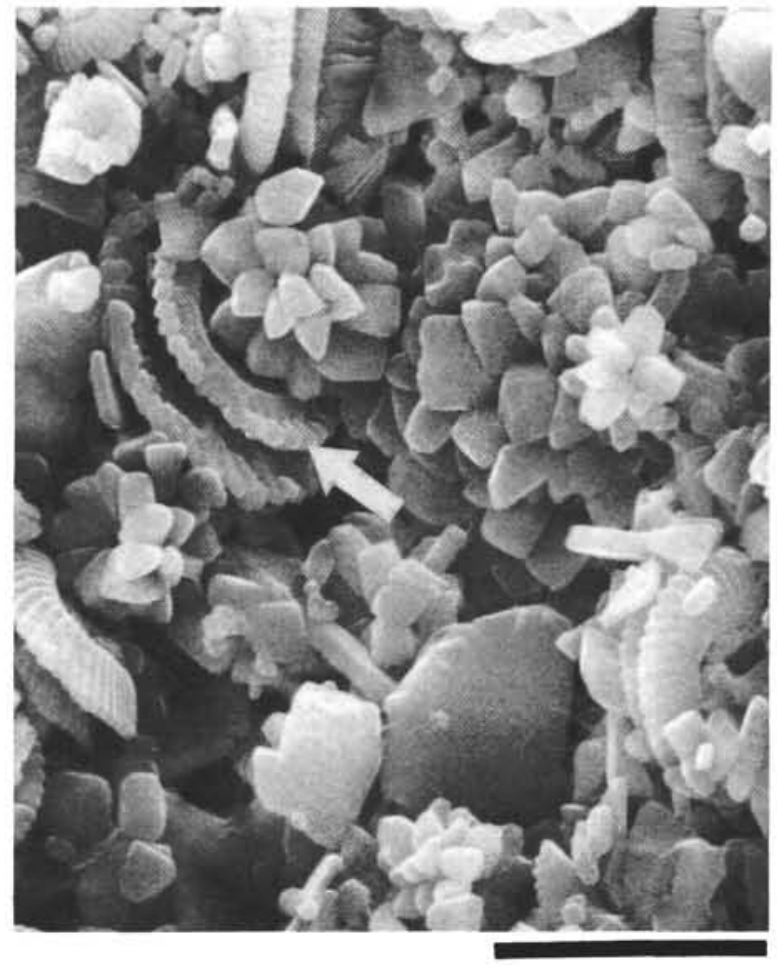

Figure 14. Site 288, 457.6 meters, early Oligocene, nanno chalk, porosity $(457.8 \mathrm{~m}) 52 \%$, scale bar $8 \mu$; radiating calcite clusters are the nannofossil Sphenolithus moriformis; these and many micarb particles show euhedral crystal faces; some coccoliths have developed extensive calcite growth along their edges (arrow).

carbonate horizons are intercalated with impure carbonate ones. A minor amount of volcanic and altered volcanic material is also present at a higher level (in samples from 887.3 and $915.8 \mathrm{~m}$ ).

The next sample illustrated comes from 1036.8 meters. The bulk X-ray data at this level indicate cristobalite, tridymite, and quartz. This relatively large amount of silica is clearly shown in the scanning electron micrographs. Figure 60 shows discoasters and coccoliths, overgrown with secondary calcite. The dense groundmass contains irregular subspherical clusters, resembling (cristobalite-tridymite) silica spherules. The discoasters in Figure 61 are coated with an amorphous "icing sugar" substance. It was suggested earlier that such "icing sugar" may be silica. This suggestion is supported in this case by the X-ray data. Note that the silica coating gives the discoaster the appearance of being strongly corroded. Figure 62 is another example of nannofossils embedded in a dense silica matrix (compare with Figure 35, Site 288). Porosity at this level is about $22 \%$.

The sample from 1047.2 is a fairly pure carbonate. Figure 63 shows recrystallized foraminiferal chambers, some of them almost entirely filled with large, freely grown calcite crystals. Figure 64 shows advanced recrystallization of cement and coccoliths. Some 


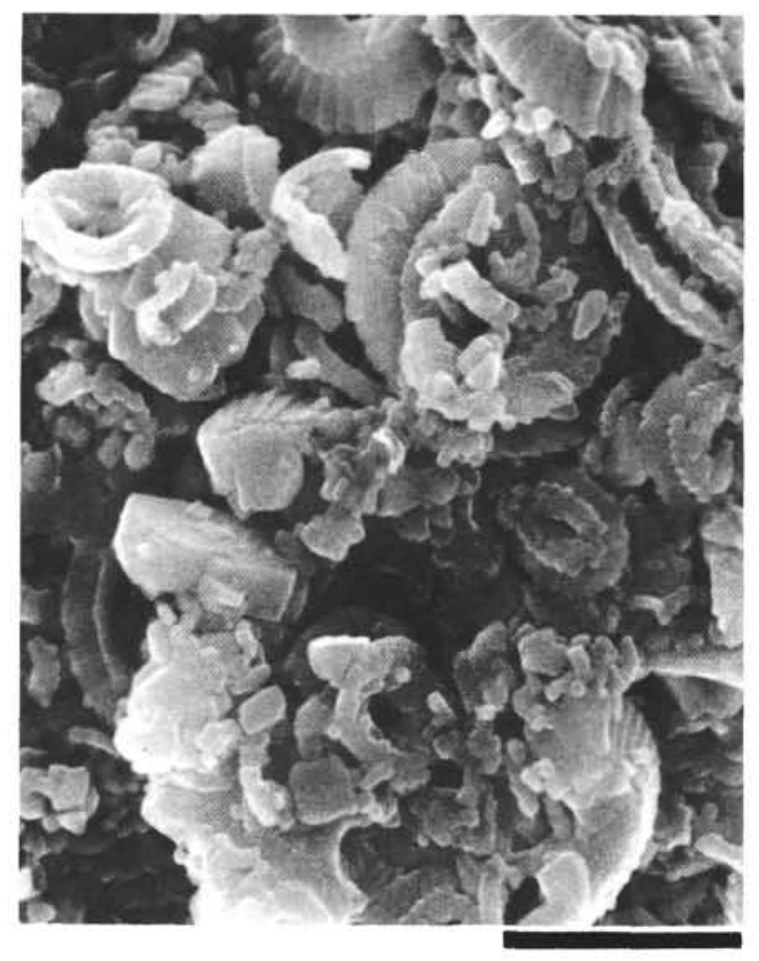

Figure 15. Site 288, 535.3 meters, late Paleocene, nanno-foram chalk, porosity $(535.1 \mathrm{~m}) 56 \%$, scale bar $12 \mu$; coccoliths and coccolith fragments showing advanced calcite overgrowth and welding. Note zeolite crystal left of center.

pressure solution can be seen. Impressions of coccoliths can be seen in some of the larger calcite crystals. Small cracks in the limestone have become filled with sparry calcite (Figure 65). The first stylolites were observed in the cores at about this level.

The X-ray data of the next sample $(1065.2 \mathrm{~m})$ indicate pure carbonate. Both dissolution and recrystallization of calcite can be seen (Figure 66).

Figure 67 (1084.2 m) shows very fine fibrous material covering a calcite substrate. This fibrous material looks like cristobalite (-tridymite). No X-ray data are available from this level.

The next photomicrograph is from a pure carbonate limestone (Figure 68, $1093.8 \mathrm{~m}$ ). It shows the common diagenetic features of this limestone interval; overgrown nannofossils, pressure solution features, welding, a matrix of coccolith fragments, and relatively large secondary calcite crystals. It has, however, some anhedral to subhedral micritic particles, common to lower diagenetic levels.

Figure $69(1130.5 \mathrm{~m})$ shows densely packed and welded coccoliths in a granular calcite matrix. Some smooth surfaces are visible ("icing sugar" silica?). Porosity is about $11 \%$.

The next sample is just below this one $(1131.6 \mathrm{~m})$. Figure 70 shows the inside of a foraminiferal chamber. The inside surface has a very peculiar texture of interlocking small rods. This structure has not been seen by the authors before. Closer examination shows these

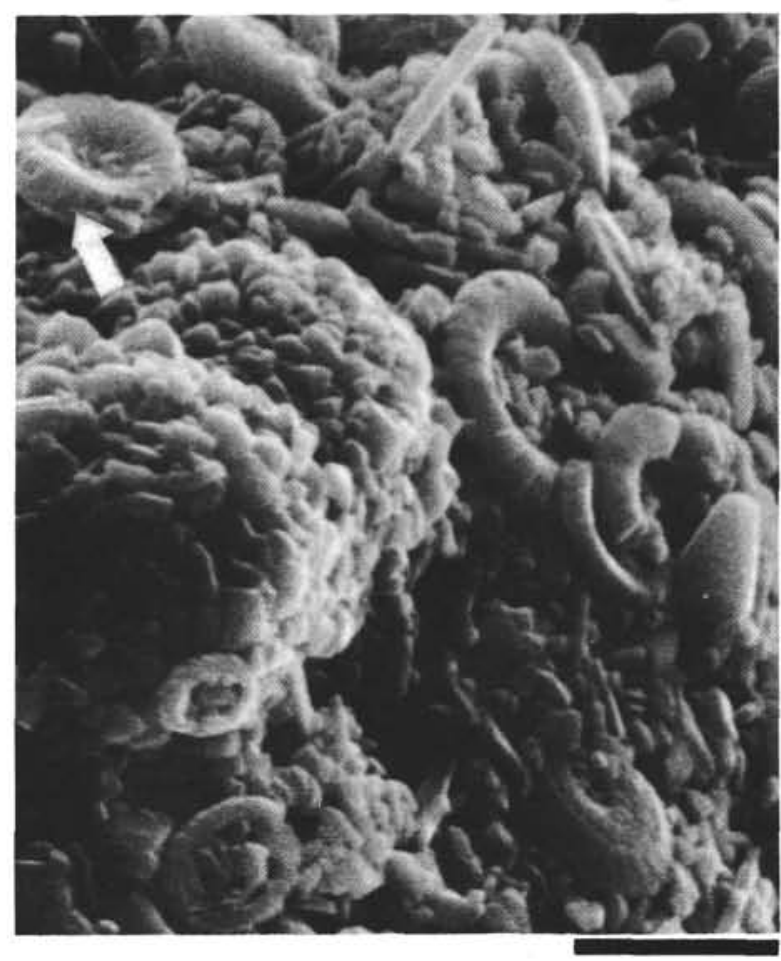

Figure 16. Site 288, 578.2 meters, middle Maestrichtian, foram-nanno ooze, porosity $(572.4 \mathrm{~m}) 52 \%$, scale bar 8 8 ; unwelded mixture of coccoliths, coccolith fragments, and foraminifera; some coccoliths well preserved, others showing secondary calcite filling in the space between proximal and distal shields (arrow); note recrystallized surface of foraminifera.

rods to be the ends of elements constructing the wall of the chamber and therefore probably consist of calcite. Foraminiferal wall structures consisting of calcite needles in a three-dimensional random array are known from the benthonic Quinqueloculina, and are considered a taxonomic characteristic of that genus (Cheriff and Flick, 1974). Though that structure does not look exactly like the one shown in Figure 70, diagenetic modification could convert it to that. However, the foraminifera in Figure 70 clearly is a planktonic species. Normal freegrowing calcite crystals are attached to the inner surface. Completely filled foraminiferal chambers are shown in Figure 71

At 1138.1 meters the sediment contains some silica again. "Icing sugar" coating is common (Figure 72). Secondary silica has filled most of the pore space (Figure 73 ), and the porosity is $7 \%$ only.

As mentioned in the description of the physical properties, there is a reversal in the general trends below 1150 meters. This level coincides with the CretaceousTertiary boundary. A similar phenomenon was observed at Site 288. Induration is generally lower than above. At both sites there is an ooze horizon in the Maestrichtian. The photomicrographs of Site 289 (Figures 74 to 76) compare closely with those of sediments of about the same age at Site 288 (Figures 16 


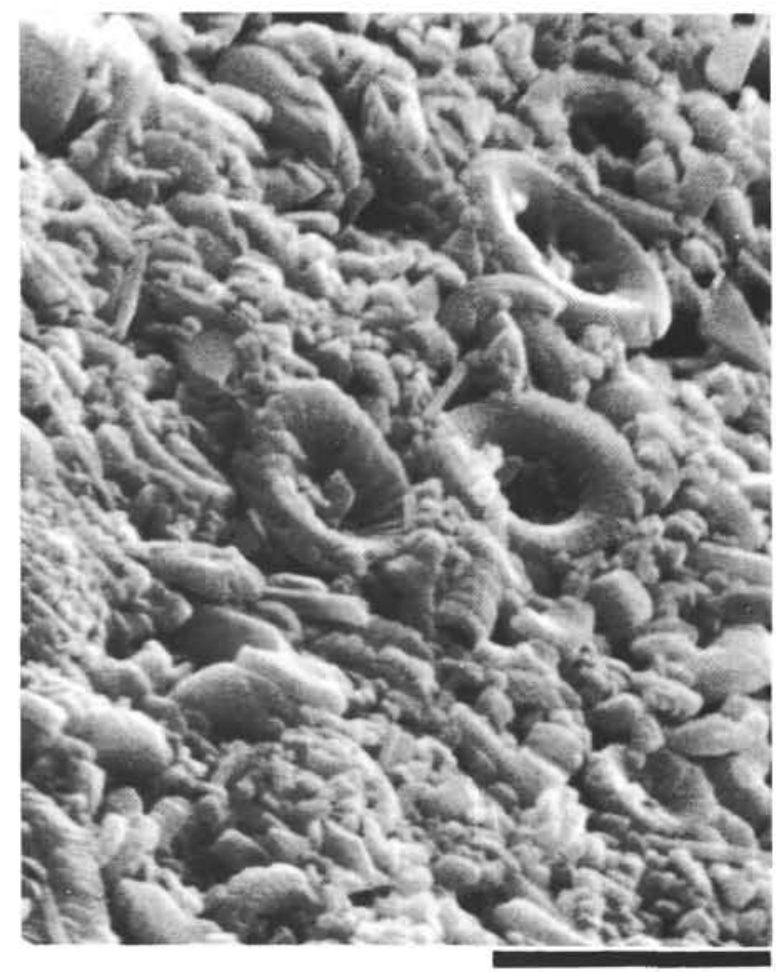

Figure 17. Site 288, 578.2 meters, middle Maestrichtian, foram-nanno ooze, porosity $(572.4 \mathrm{~m}) 52 \%$, scale bar $8 \mu$; unwelded mixture of coccoliths and micarb particles; note well-preserved coccolith in upper right-hand corner; the coccolith left of center has the intershield space filled up with secondary calcite.

and 17). Particles are loosely packed and hardly any welding is present (Figure 74, $1155.8 \mathrm{~m}$ ). Some of the coccoliths show a lower degree of overgrowth (Figure $76,1175.3 \mathrm{~m})$. Foraminifera are less filled with new calcite (Figure $75,1167.4 \mathrm{~m}$ ). Porosity has increased to $40 \%$.

However, as at Site 288, the diagenetic stage is not very much lower than directly above. It certainly never returns to the level of the ooze at the top of the section.

At 1203.9 meters, diagenesis seems to have "picked up" again. Porosity has decreased to about 17\%. Figure 77 shows a densely packed, and somewhat welded, mass of angular fossil fragments and crystals. Figure 78 $(1231.0 \mathrm{~m})$ shows a similar picture. Pressure solution can be observed. Most micarb particles have perfect euhedral shapes. Some coccoliths have smooth surfaces, probably due to solution (no sign of silica coating). Others show well-developed crystal faces.

Figure $79(1231.6 \mathrm{~m})$ is from the surface of a slickensided fault. This surface is coated with clay minerals. A similar phenomenon was described by Packham and van der Lingen (1973, Plate 7, fig. 5), and was explained by dissolution and migrating away of the calcite from the fault surface.

The last sample photographed is a silicified, impure limestone (Figure 80, $1232.7 \mathrm{~m}$ ). It shows a dense matrix with imprints of nannofossils (porosity about $18 \%$ ). Similar imprints were also described from Site 288 (Figure 23, 742-743 m).

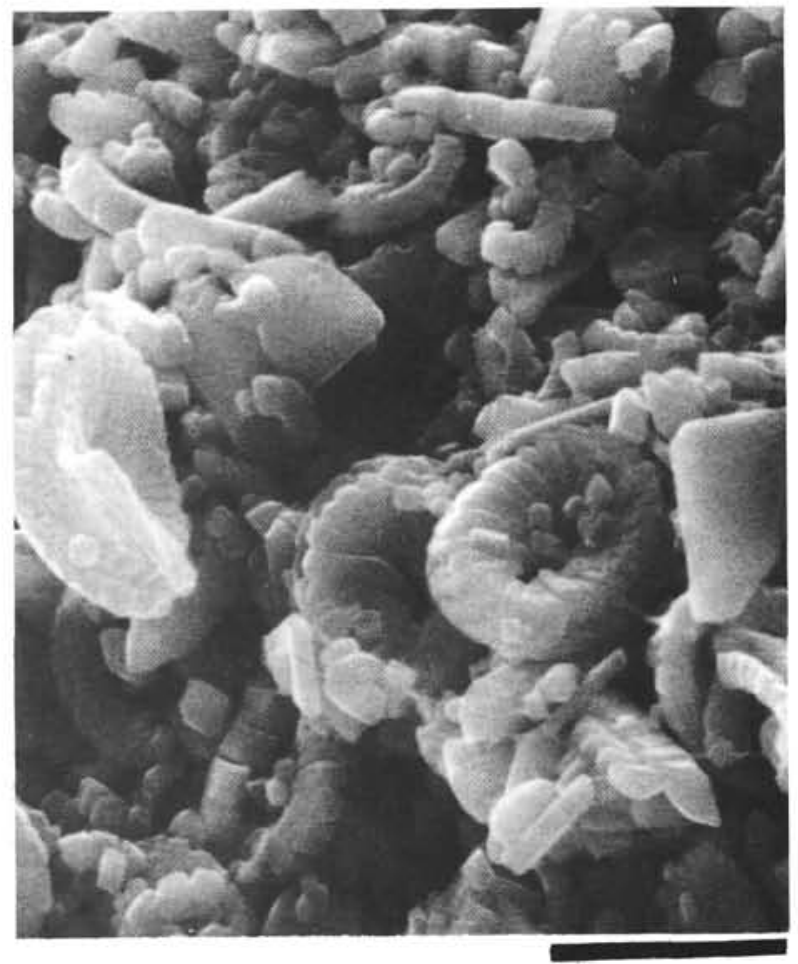

Figure 18. Site 288, 650.0 meters, Campanian, nanno chalk, porosity $(648.4 \mathrm{~m}) 51 \%$, scale bar $12 \mu$; coccoliths and coccolith fragments welded together; note angular "keystone" plates, typical of Mesozoic forms, extensive secondary calcite growth; note wisp-like bridging structures.

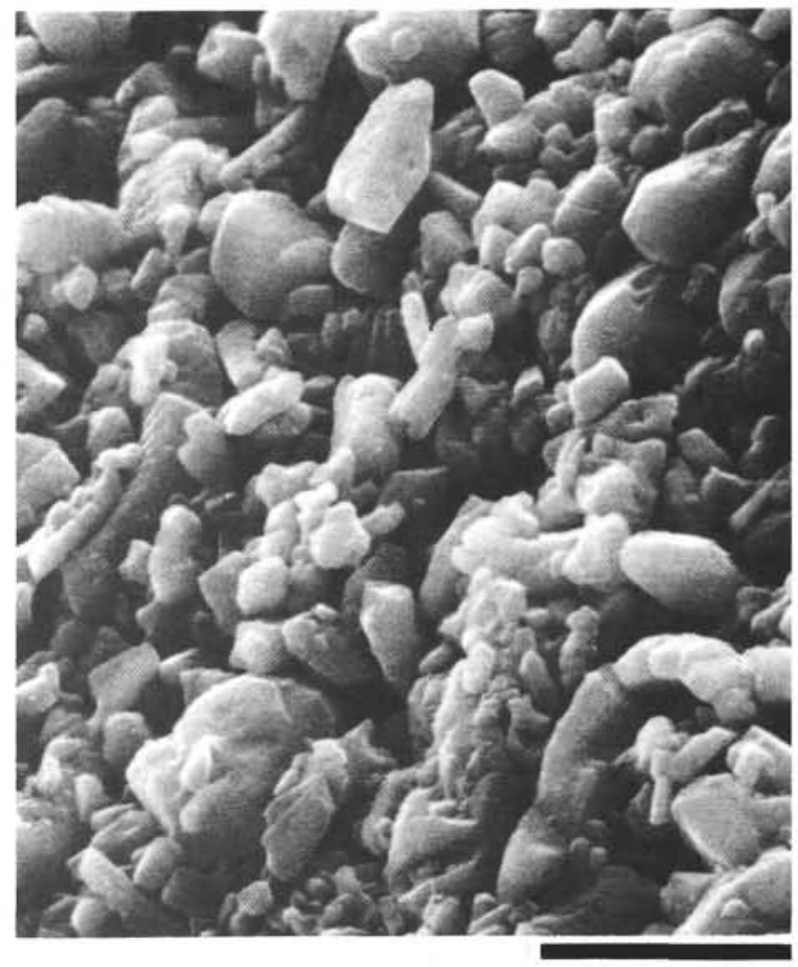

Figure 19. Site 288, 650.0 meters, Campanian, nanno chalk, porosity ( $648.4 \mathrm{~m}$ ) $51 \%$, scale bar $8 \mu$; densely packed coccoliths and subhedral granular calcite. 


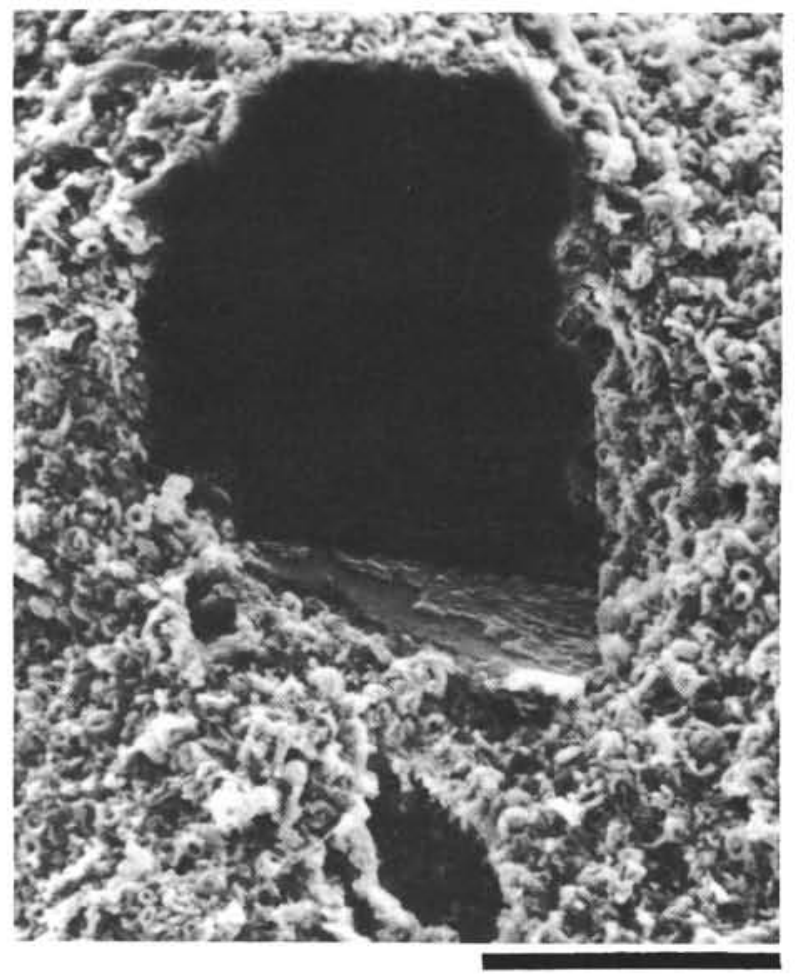

Figure 20. Site 288, 650.0 meters, Campanian, nanno chalk, porosity $(648.4 \mathrm{~m}) 51 \%$, scale bar $80 \mu$; hollow, formerly containing a dolomite rhomb.

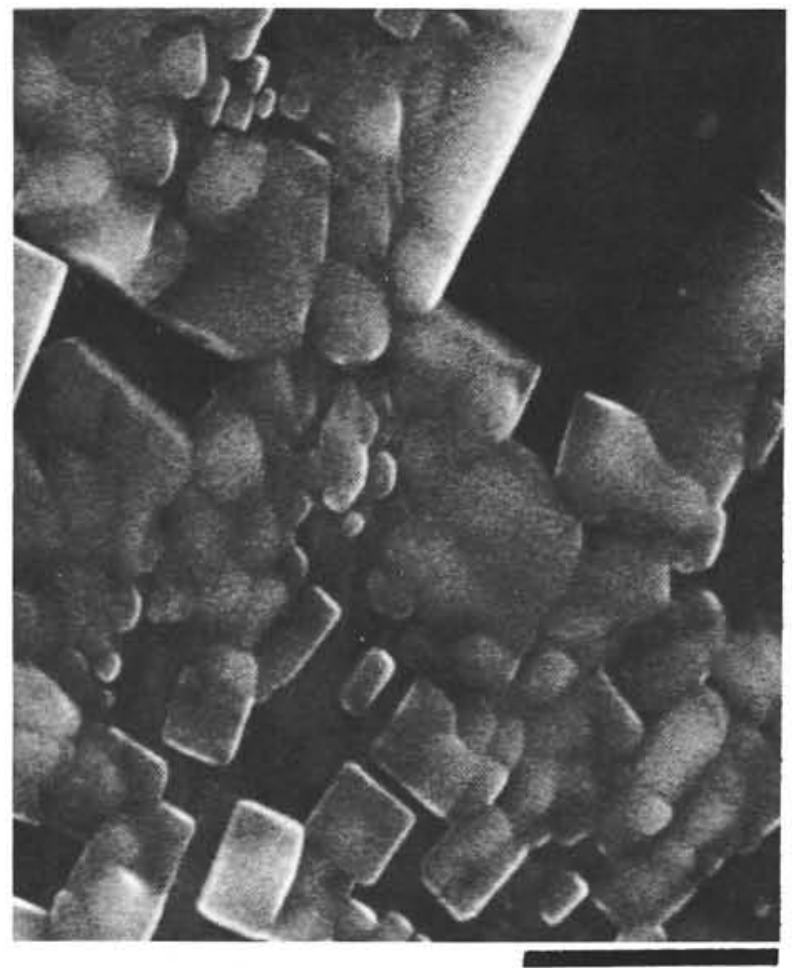

Figure 21. Site 288, detail of Figure 20, scale bar $8 \mu$; bottom of hollow covered with small dolomite rhombs.

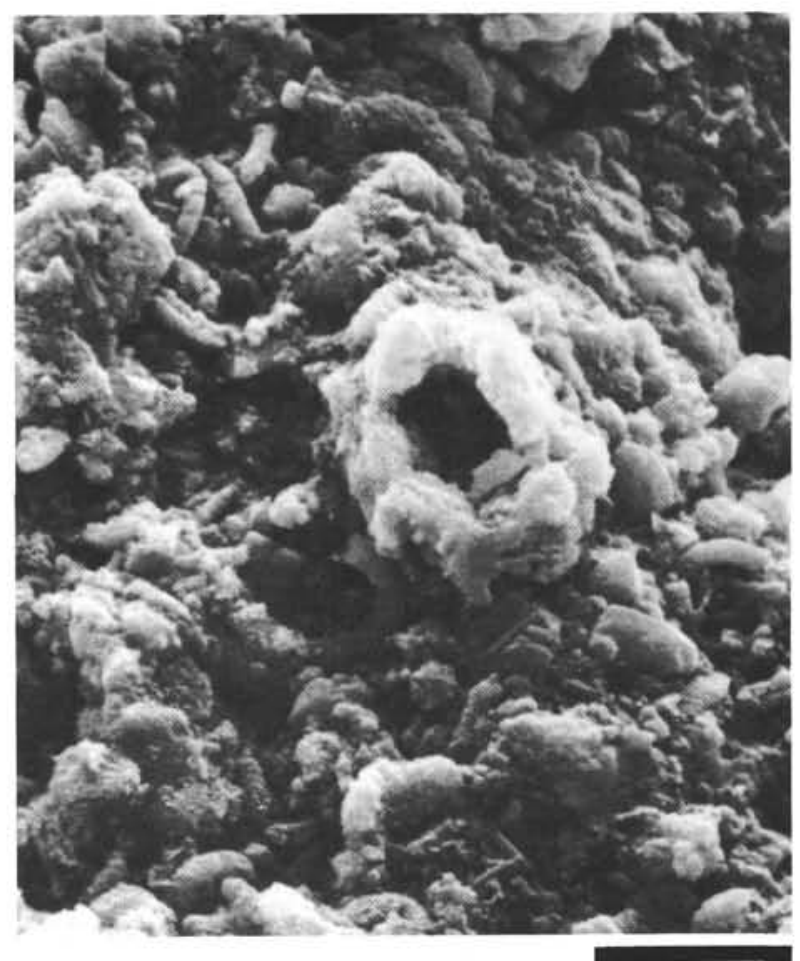

Figure 22. Site 288, 705.5 meters, Santonian, nanno chalk, porosity $(705.5 \mathrm{~m}) 36 \%$, scale bar $20 \mu$; coccoliths in a dense matrix of largely nonbiogenic (volcanic) material.

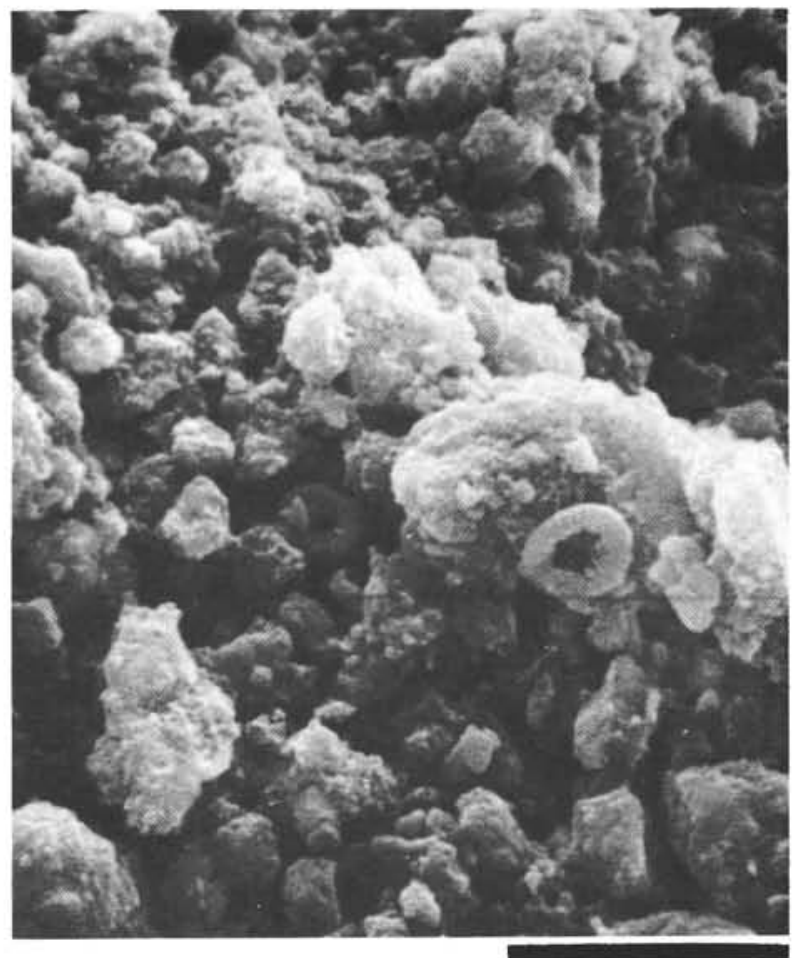

Figure 23. Site 288, 818.3 meters, Coniacian-Turonian, zeolite-rich claystone, porosity $(818.4 \mathrm{~m}) 51 \%$, scale bar $20 \mu$; sporadic nannofossils in a volcanogenic clay matrix. 


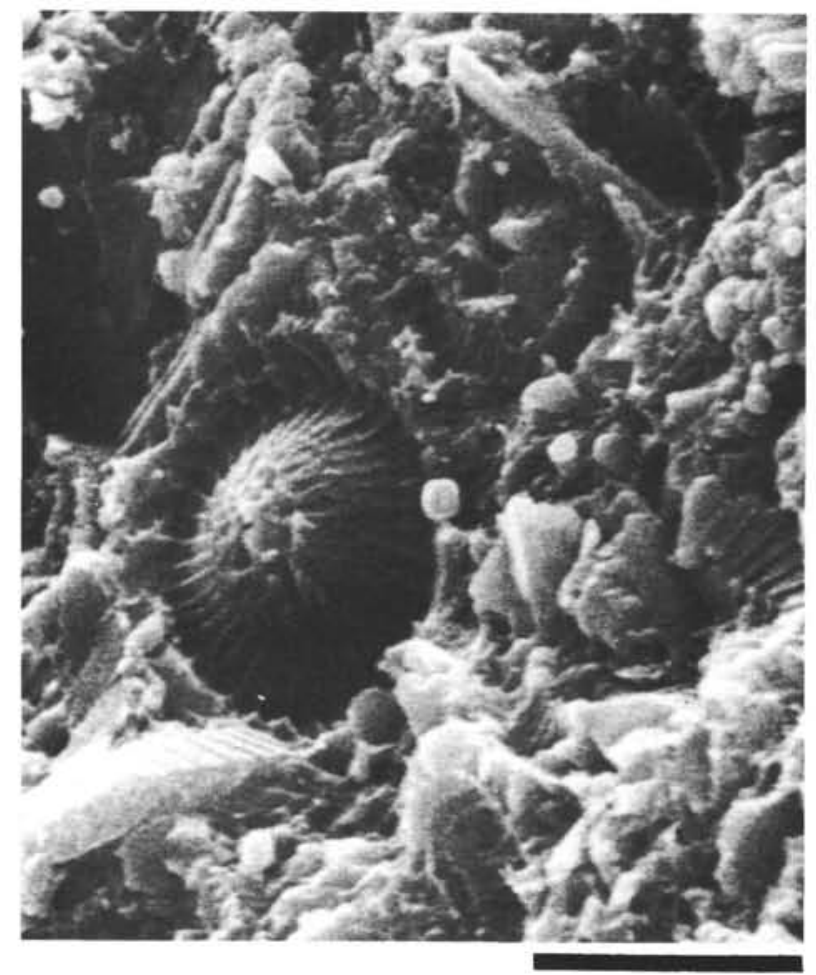

Figure 24. Site 288, 743.2 meters, late Coniacian, nanno chalk, porosity $(743.3 \mathrm{~m}) 43 \%$, scale bar $6 \mu$; coccoliths and coccolith impressions in a dense, largely nonbiogenic (volcanic) matrix.

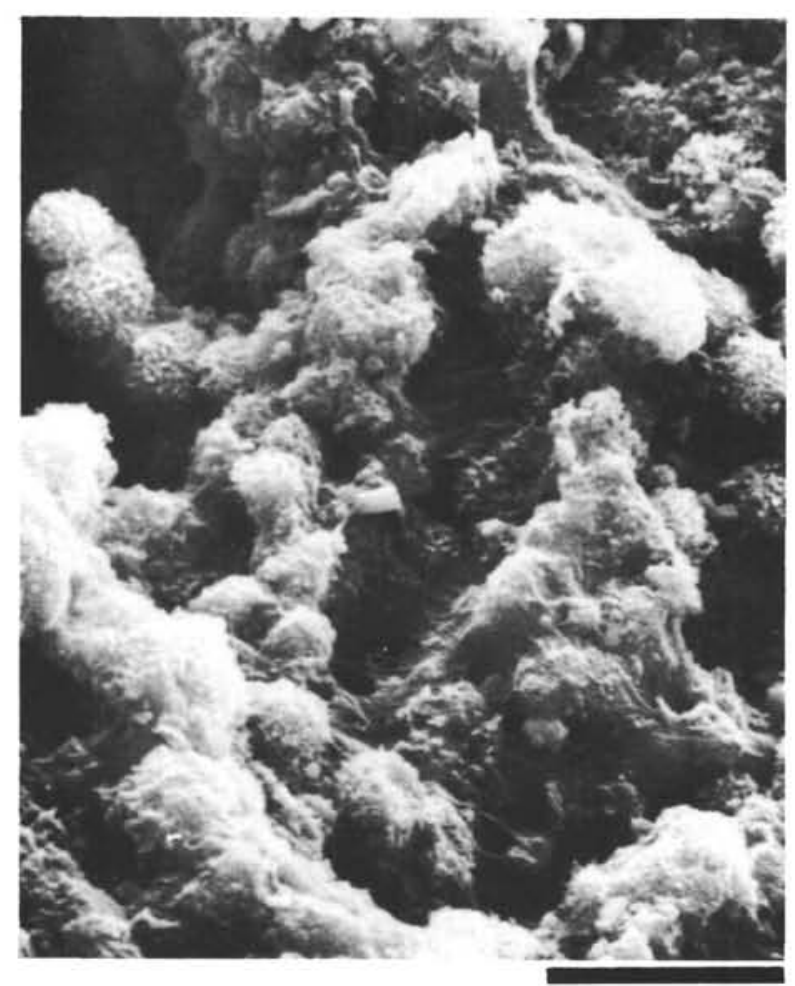

Figure 25. Site 288, 818.3 meters, Coniacian-Turonian, zeolite-rich claystone, porosity $(818.4 \mathrm{~m}) 51 \%$, scale bar $16 \mu$; imperfectly formed silica spherules.

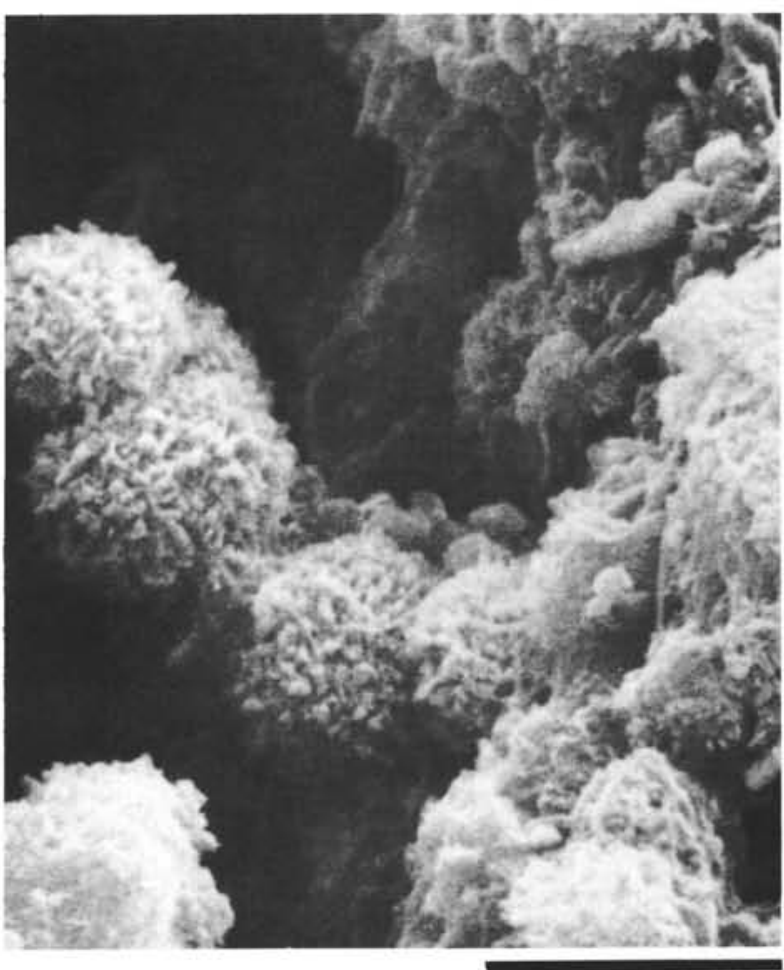

Figure 26. Site 288, detail of Figure 25, scale bar $8 \mu$; silica spherules with "sugary" surface.

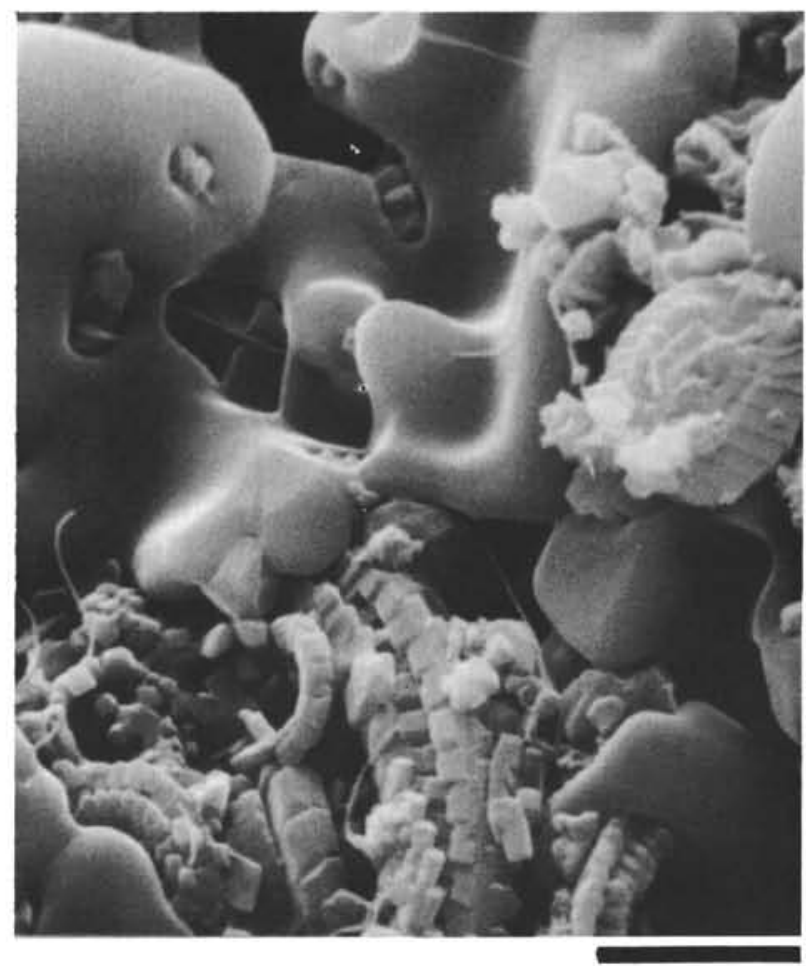

Figure 27. Site 288, 847.0 meters, ?Turonian, foramnanno chalk, porosity $(847.0 \mathrm{~m}) 35 \%$, scale bar $8 \mu$; angular coccoliths (Mesozoic forms) with minor secondary calcite overgrowth. Smooth shapes are probably artifacts (fungi?). 


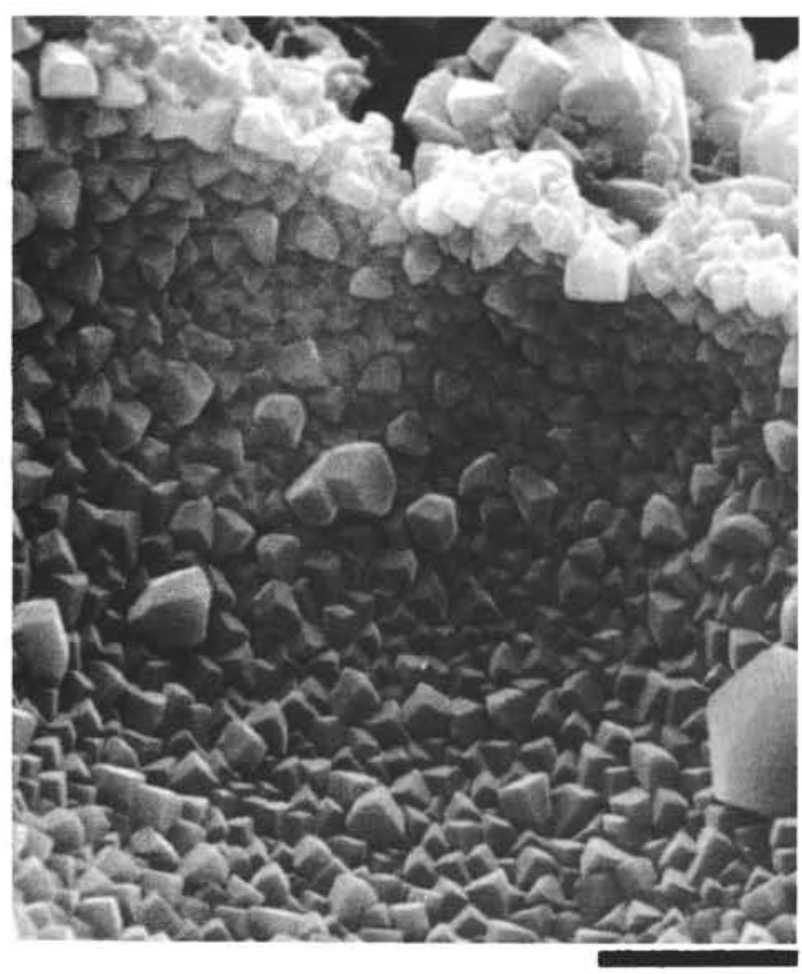

Figure 28. Site 288, 847.0 meters, ?Turonian, foramnanno chalk, porosity $(847.0 \mathrm{~m}) 35 \%$, scale bar $8 \mu$; euhedral calcite crystals inside a foraminiferal chamber.

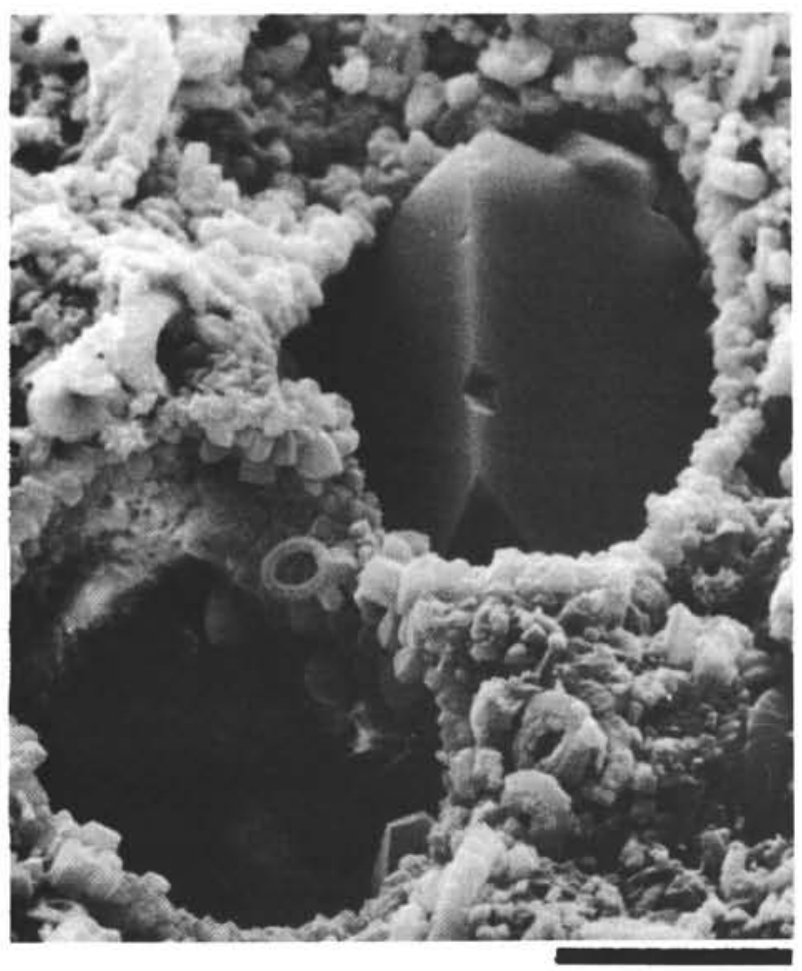

Figure 29. Site 288, 847.0 meters, ?Turonian, foramnanno chalk, porosity $(847.0 \mathrm{~m}) 35 \%$, scale bar $20 \mu$; foraminiferal chambers; one filled with single diagenetic crystal; walls recrystallized.

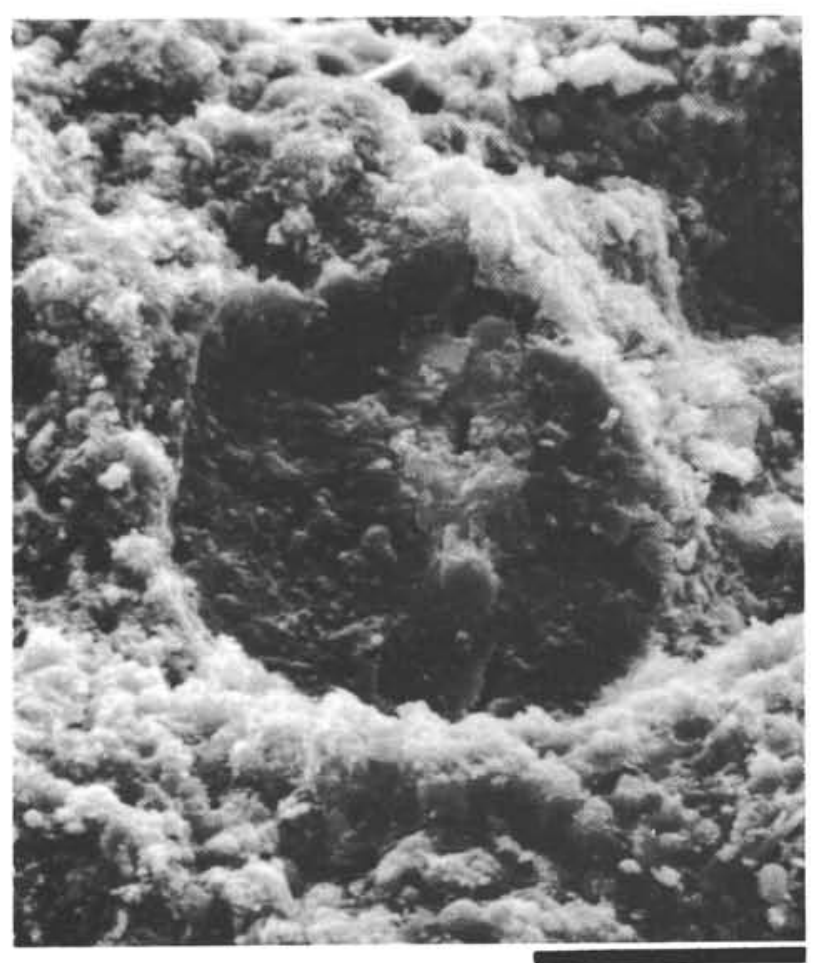

Figure 30. Site 288, 850.8 meters, ?Turonian, silicified limestone, porosity $(850.7 \mathrm{~m}) 35 \%$, scale bar $40 \mu$; silicosphere, a spherical object (radiolarian?) filled with secondary silica; the matrix surrounding the silicosphere for the greater part also consists of silica.

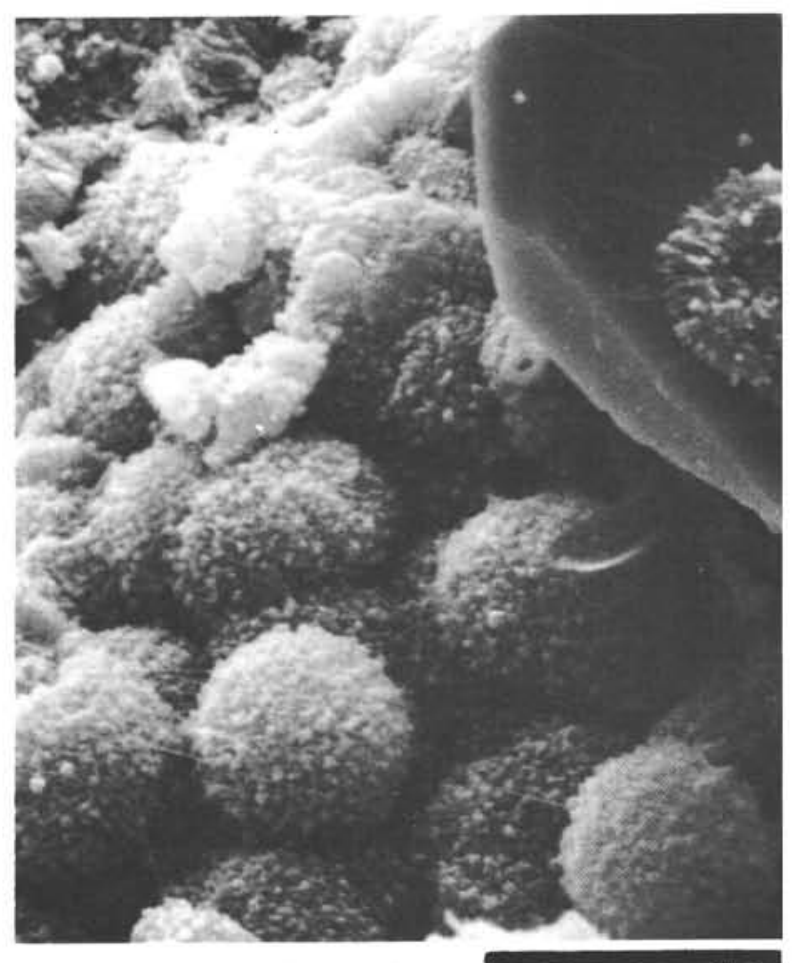

Figure 31. Site 288, 850.8 meters, ?Turonian, silicified limestone, porosity $(850.7 \mathrm{~m}) 35 \%$, scale bar $20 \mu$; silica spherules with sugary surface, and euhedral clinoptilolite crystal. 


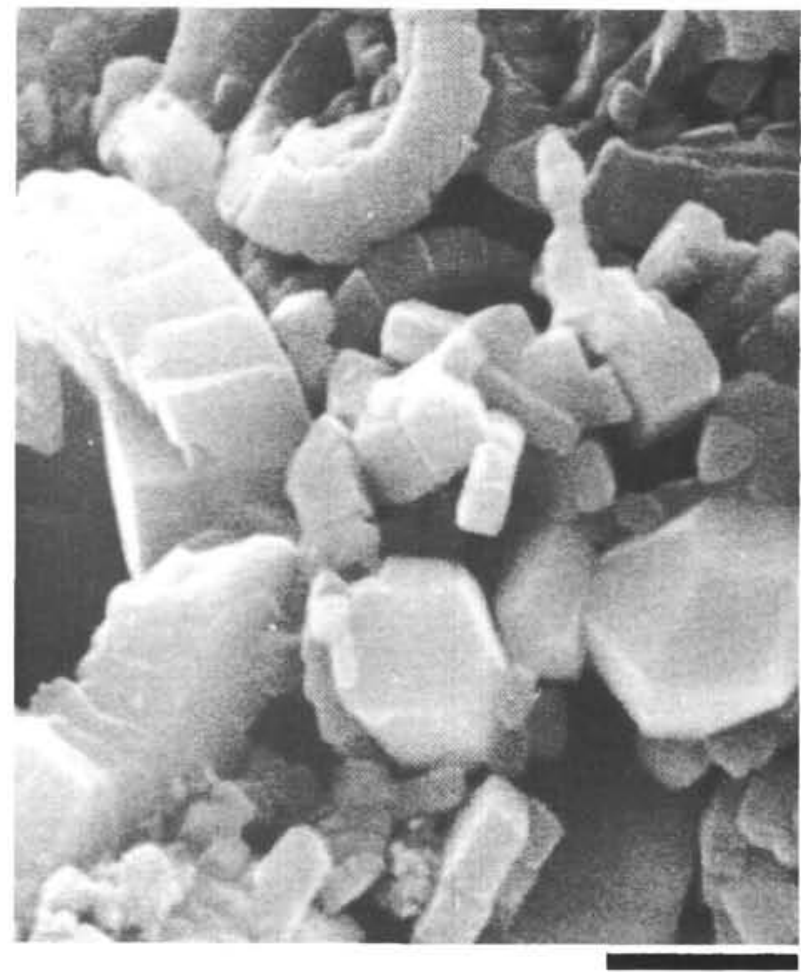

Figure 32. Site 288, 867.8 meters, ?Turonian, chertbearing nanno limestone, porosity $(867.8 \mathrm{~m}) 22 \%$, scale bar $2 \mu$; extensive development of secondary calcite, welding particles together; note relatively large euhedral calcite cement.

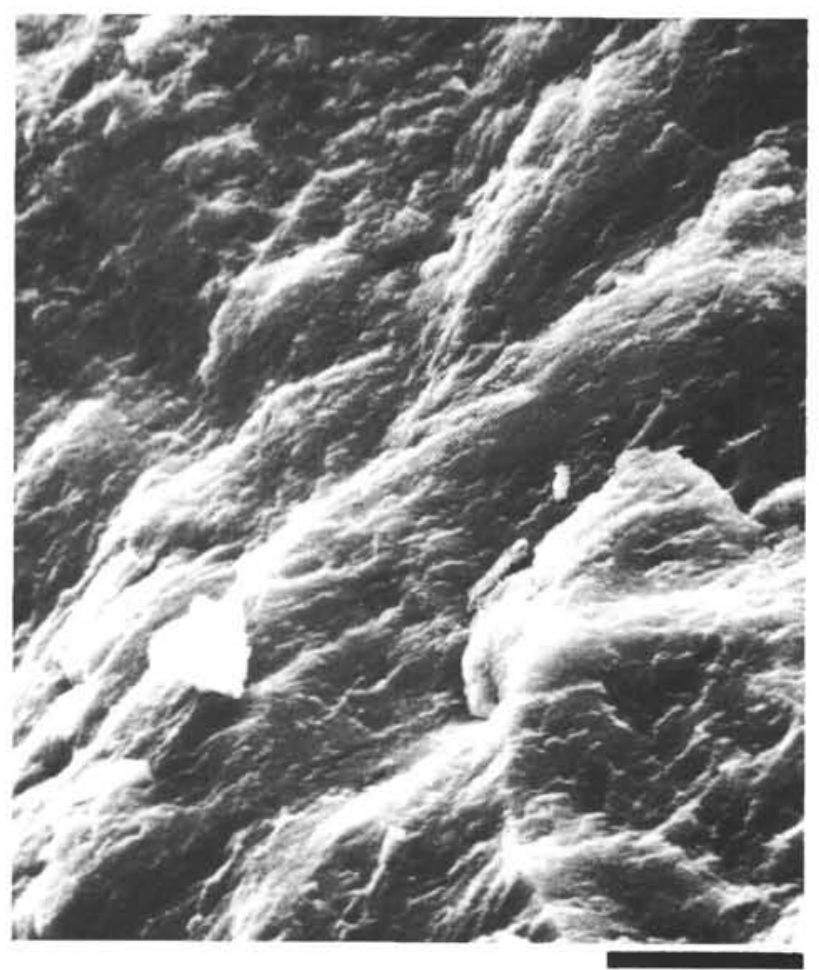

Figure 33. Site 288, 867.8 meters, ?Turonian, chert in nanno limestone, scale bar $8 \mu$; smooth breakage surface of chert nodule.

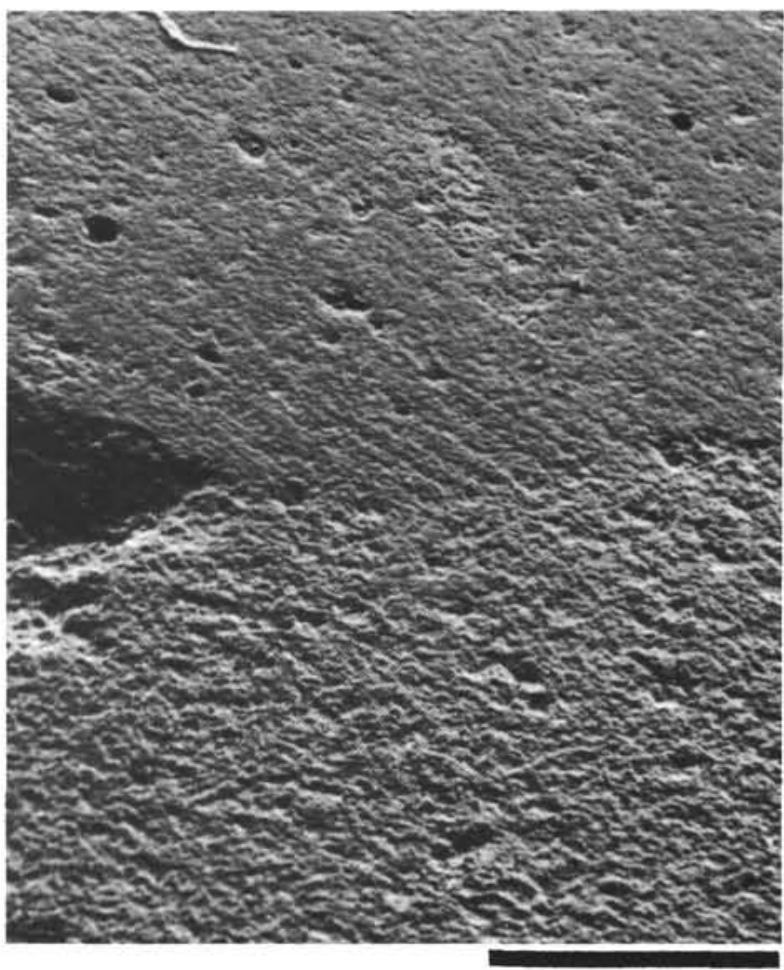

Figure 34. Site 288, 879.5 meters, early Turonian, chert-bearing nanno limestone, porosity $(875.8 \mathrm{~m})$ $27 \%$, scale bar $800 \mu$; boundary between chert (upper half of picture) and silicified limestone (lower half).

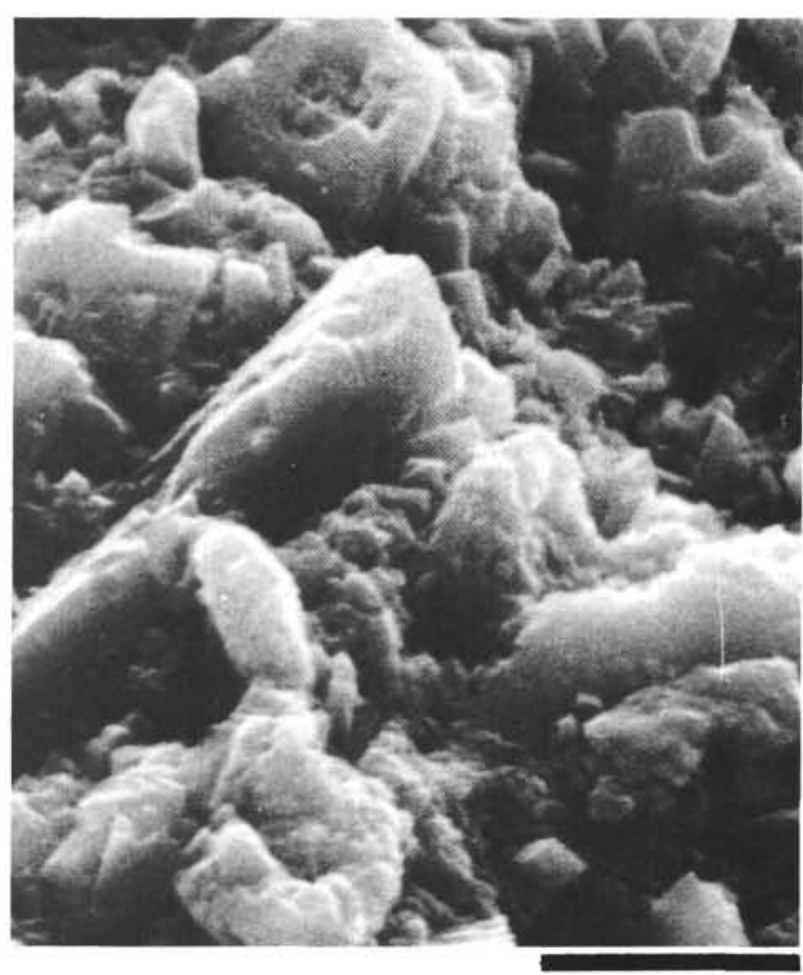

Figure 35. Site 288, 879.5 meters, detail of Figure 34, scale bar $6 \mu$; silicified limestone part, showing coccoliths embedded in a silica matrix. 


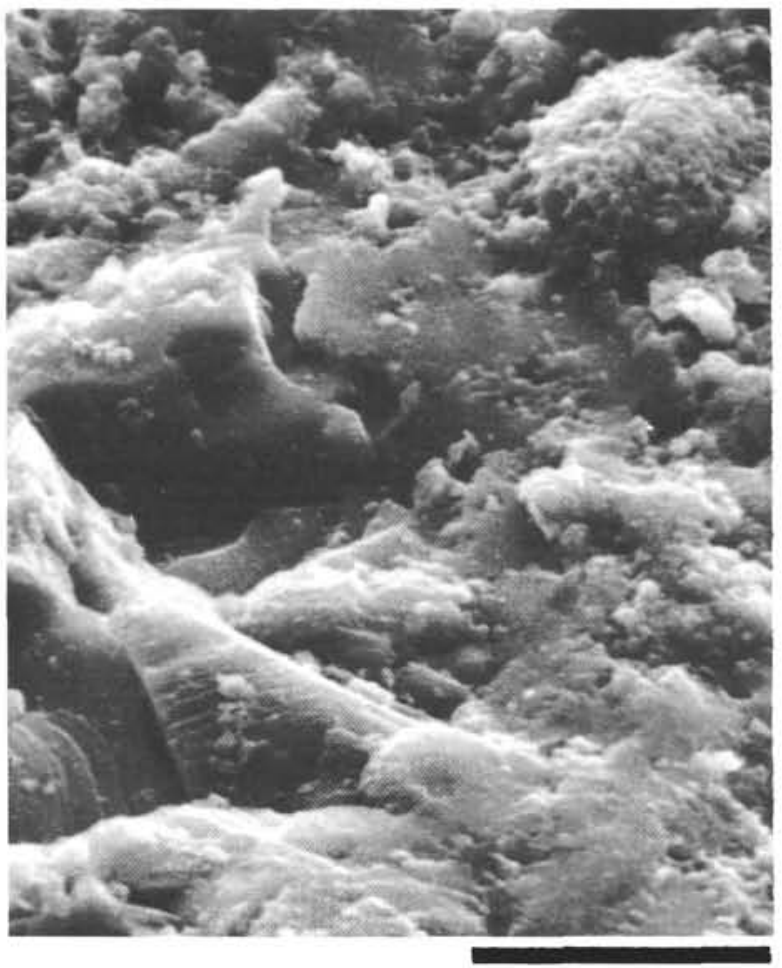

Figure 36. Site 288, 879.5 meters, detail of Figure 34, scale bar 20 ; chert part, showing smooth silica surface with fracture marks; spherical object in upper right corner may be recrystallized radiolarian.

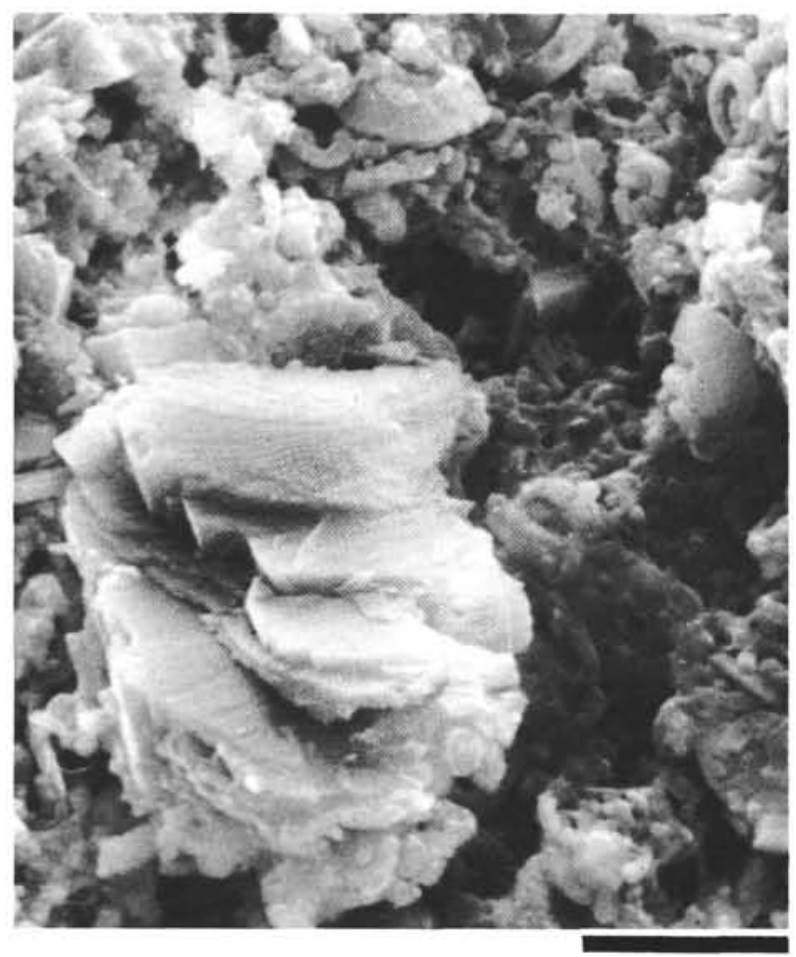

Figure 37. Site 288, 894.5 meters, Cenomanian, limestone, porosity $(894.9 \mathrm{~m}) 29 \%$, scale bar $10 \mu$; subspherical object ("silicosphere"), consisting of radiating sheet-like silica (probably chalcedony); matrix contains abundant coccoliths in a silica groundmass.

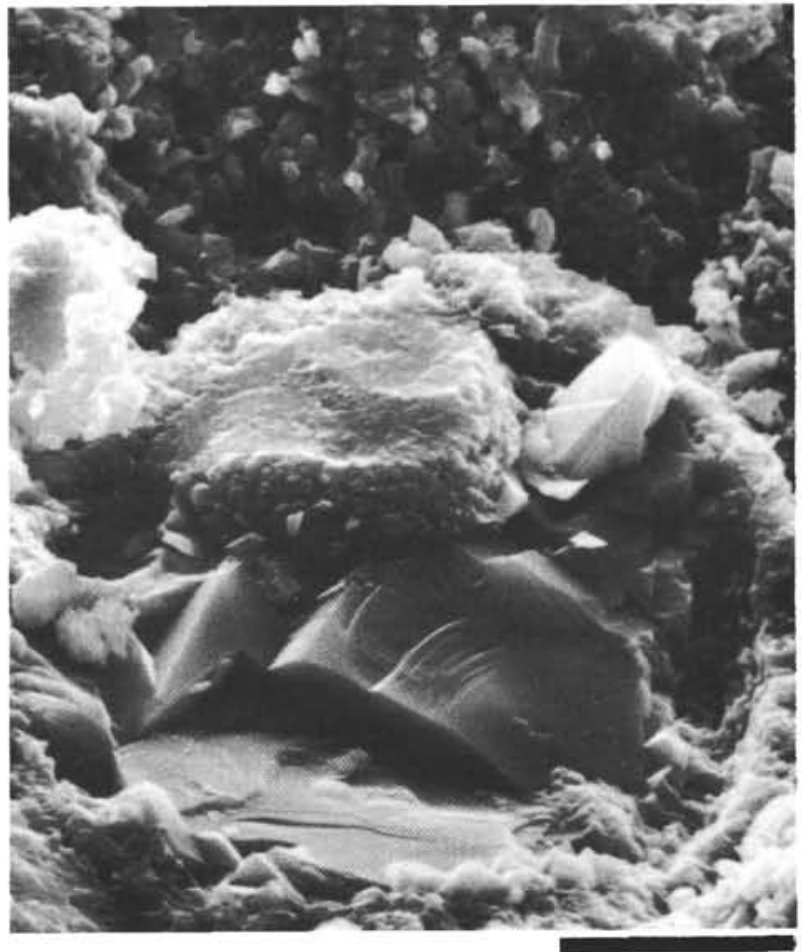

Figure 38. Site 288, 979.9 meters, Aptian, silicified limestone, porosity $(980.4 \mathrm{~m}) 25 \%$, scale bar $20 \mu$; silicosphere, a spherical fossil (foraminifera?) filled with chalcedony.

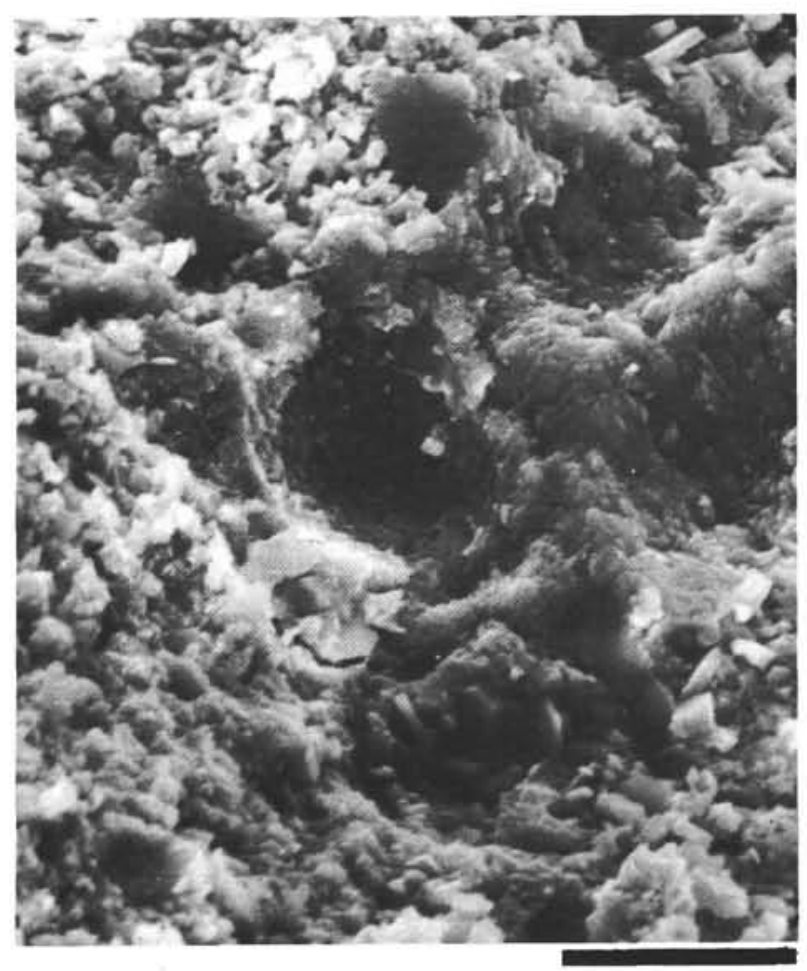

Figure 39. Site 288, 979.9 meters, Aptian, silicified limestone, porosity $(980.4 \mathrm{~m}) 25 \%$, scale bar $20 \mu$; faint outline of a silicified foraminifera 14 chambers showing); groundmass is a dense mixture of nannofossils and secondary silica. 


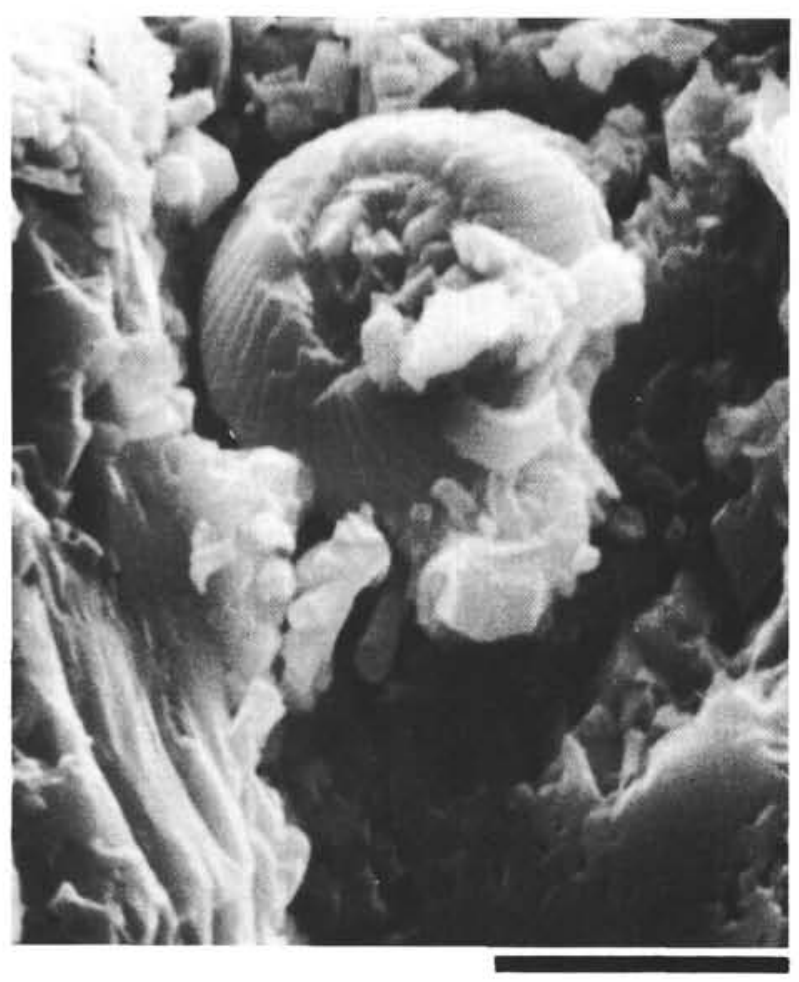

Figure 40. Site 288, 979.9 meters, Aptian, silicified limestone, porosity (980.4 m) $25 \%$, scale bar $20 \mu$; fairly well preserved coccolith in a dense, silicified matrix; some calcite overgrowth in the central part of the coccolith.

\section{CORRELATION WITH SEISMIC REFLECTORS}

Earlier in this paper mention was made of correlations of major seismic reflectors with sediment physical properties and scanning electron microscopic features for drill sites in the Southwest Pacific by Packham and van der Lingen (1973). Their findings can be further tested on the data from Sites 288 and 289 . Because of the more complete sampling at Site 289 and the absence of chert in the post middle Eocene, the thick ooze section there is ideal for this purpose. At Site 288, as indicated above, the acoustic behavior of the sequence differs considerably from that at Site 289 , this is in part due to the presence of more chert in the column.

\section{Site 289}

The shallowest reflector (very weak) is at about 140 meters in the upper Pliocene in the vicinity of the change of the ooze from creamy to stiff, but lies above the level where drilling disturbance drops significantly (250-300 $\mathrm{m})$. The first reflector corresponds to a small step in the acoustic impedance (see site report) resulting mainly from a slight change in the density curve.

The 250-300 meter zone in which the degree of drilling disturbance drops does not slow any significant excursion in the acoustic impedance, nor is there a major reflection event.

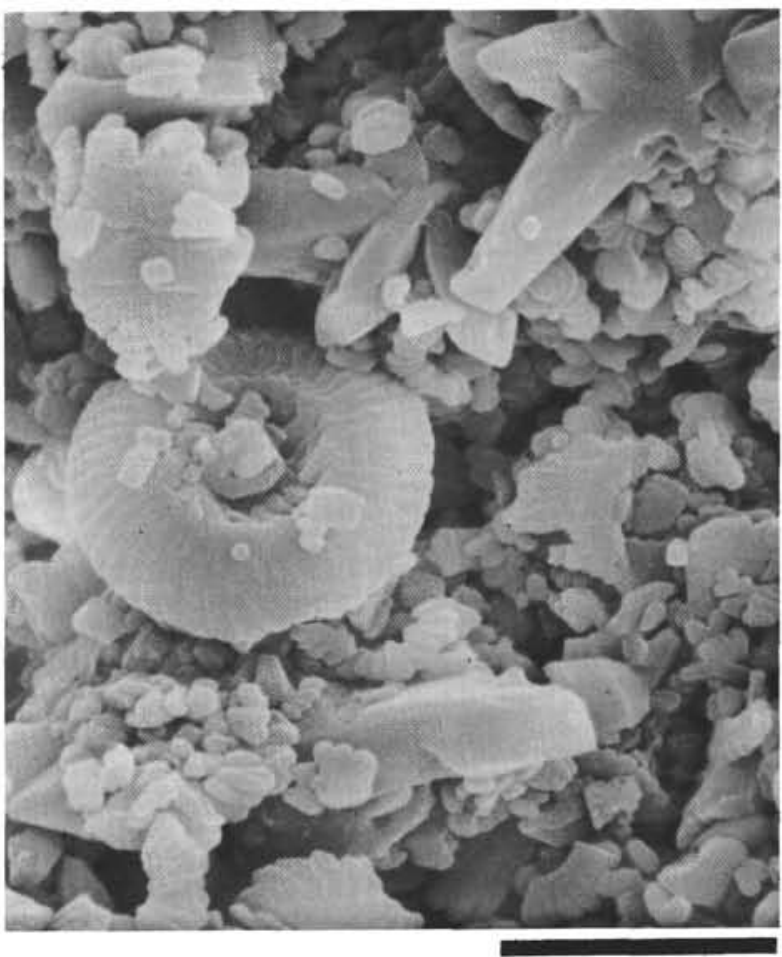

Figure 41. Site 289, 468.9 meters, middle Miocene, nanno-foram chalk/ooze, porosity $(467.3 \mathrm{~m}) 55 \%$, scale bar $5 \mu$; overgrown discoasters; coccoliths and coccolith fragments, showing both dissolution and reprecipitation; some welding by secondary calcite; note abundant anhedral micarb particles.

A moderately strong reflection corresponds to a depth of 376 meters in middle Miocene stiff to semilithified ooze. There is no significant peak in the acoustic impedance curve, but this is the level at which there is a change in gradient in the depth velocity curve.

The third reflector at an estimated depth of 535 meters is in lower Miocene semilithified to stiff chalk. From this level onwards down the hole, the amplitude of the excursions acoustic velocity curve becomes significantly greater and the anisotropy between vertical and horizontal velocities increase. This clearly marks a change in the degree of lithification of the sediments.

Although SEM examination shows an increase in the amount of welding of grains and the development of overgrowths, the most significant change at this level is probably a change in the distribution of grain contacts (? and orientation) indicated by the increased anisotropy. The wide variation in velocities indicates that some layers and more susceptible to modification than others. In terms of macroscopic features, this reflector marks the lower limit of significant drilling disturbance.

The fourth reflector corresponds to an estimated depth of 652 meters in semilithified chalk at the Miocene-Oligocene boundary. There is a broad low in the acoustic velocity at this depth between maxima at 600 and 700 meters, but no corresponding low in the 


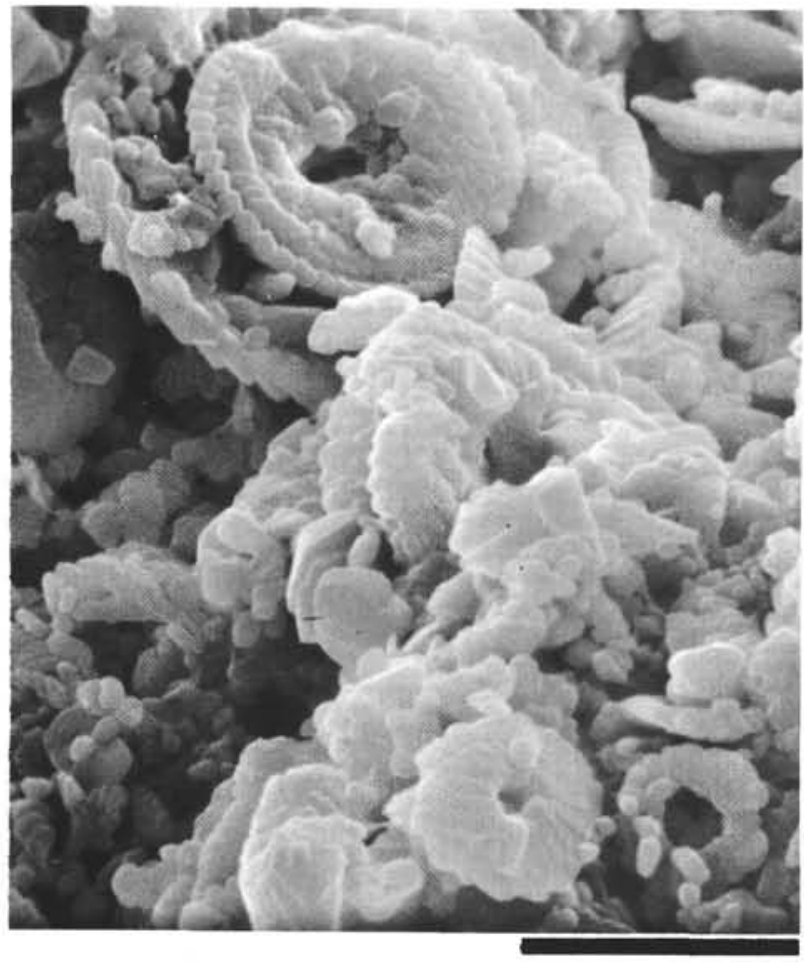

Figure 42. Site 289, 562.4 meters, early Miocene, nannoforam chalk, porosity $(562.7 \mathrm{~m}) 53 \%$, scale bar $5 \mu$; pronounced calcite overgrowth on fossil particles, and substantial welding.

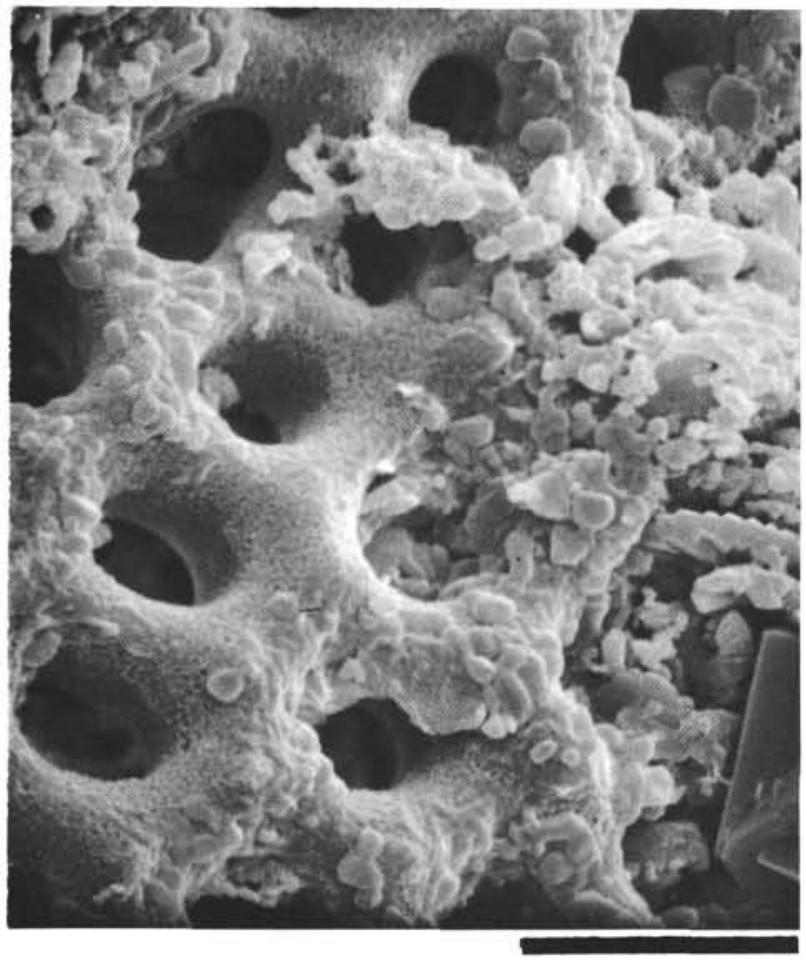

Figure 43. Site 289, 620.4 meters, early Miocene, nannoforam chalk, porosity $(620.3 \mathrm{~m}) 55 \%$, scale bar $10 \mu$; slightly corroded radiolarian, covered with clusters of subhedral micarb particles; some overgrowth on coccoliths.

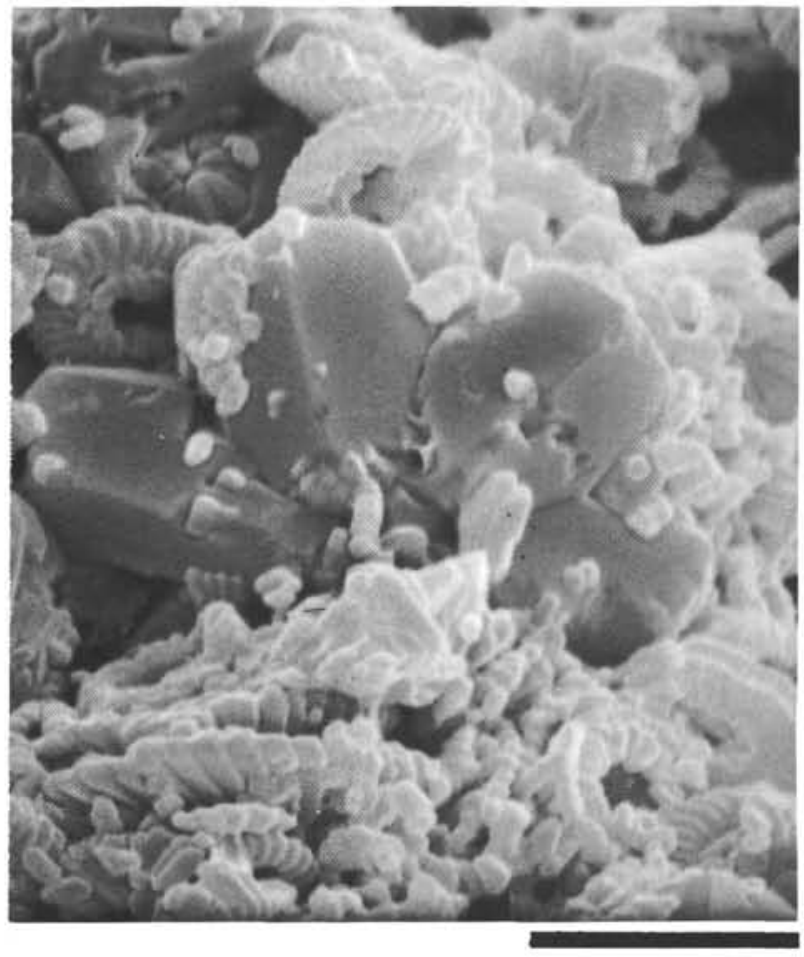

Figure 44. Site 289, 620.4 meters, early Miocene, nannoforam chalk, porosity $(620.3 \mathrm{~m}) 55 \%$, scale bar $5 \mu$; discoaster with secondary calcite overgrowth, showing some pitting; substantial overgrowth on coccoliths.

density or increase in porosity. The explanation of this low probably lies in the nature and frequency of grain contacts. Velocity anisotropy is at a minimum also. No clear explanation can be obtained from examination of the SEM photographs, but there is a strong suggestion of grain dissolution.

The first of the strong reflection events is at an estimated depth of 711 meters in upper Oligocene chalk. At this depth there is another velocity low immediately below the 700-meter maximum indicated above, thus resulting in a significant reflection coefficient. An SEM examination of a sample from 704.8 meters (Figure 48) shows pronounced dissolution of coccoliths as well as precipitation of secondary calcite. The solution may be responsible for decreasing grain contacts and impeding sound transmission.

The next strong reflector is at an estimated depth of 814 meters, again in upper Oligocene chalk. Sediment velocity measurements indicate a low immediately above this level and a high corresponding to it. The evidence available suggests that this reflector is of similar origin to the two strong reflectors immediately above. The next reflector at an estimated 873 meters is also a strong one and may correspond to a further velocity low at 885 meters where grain solution has again been observed.

The next reflector has been placed near the base of the lower Oligocene chalk at 950 meters and does not correspond to any significant excursion in the acoustic impedance curve. At this level the welding of grains is further advanced. 


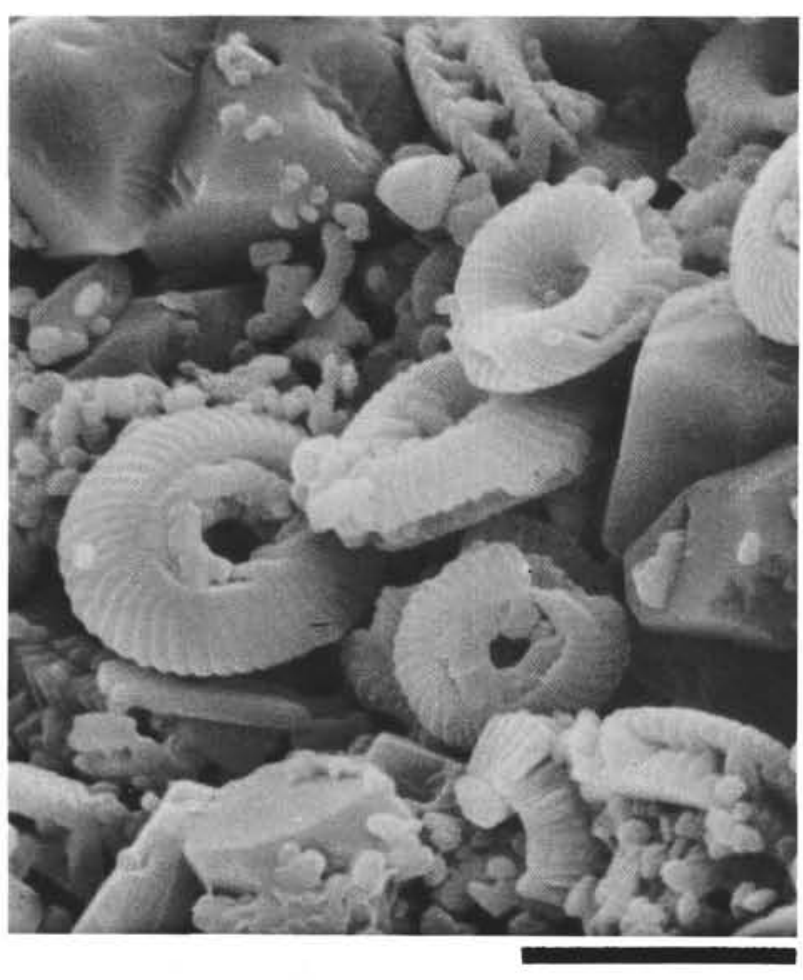

Figure 45. Site 289, 657.5 meters, late Oligocene, nannoforam chalk/ooze, porosity $(657.7 \mathrm{~m}) 54 \%$, scale bar $5 \mu$; secondary calcite overgrowth on discoasters has incorporated other fossil fragments (see also coccolith impressions in calcite); secondary calcite fills the central parts of coccoliths and bridges the space between placolith shields; note corrosion of some coccoliths.

The velocity data indicate that the next reflector is located at 1004 meters in upper Eocene chalk. However, it is most likely that this is some 20 meters too high. At this lower level in the middle Eocene there is a sudden downwards increase in sonic velocity, bulk density, and a decrease in porosity. SEM photographs indicate a sudden increase in the quantity of diagenetic overgrowths. Minor quantities of chert are also present.

In general, below this level, the acoustic impedance increases steadily to 1138 meters, it then decreases sharply at about 1150 meters. Although the grains in this lower velocity sediment display considerable diagenesis, they are loosely packed. The weak reflector with an estimated depth of 1144 meters probably correspond to this change.

The deepest reflector identified is at $1.26 \mathrm{sec}$ two-way travel time subbottom and is tentatively placed at 1232 meters at the base of the chalk horizon. It may alternatively represent the limestone-basalt contact at 1262 meters.

\section{Site $\mathbf{2 8 8}$}

Because coring was not continuous at this site, it is not possible to define the depth velocity curve with the same degree of accuracy as at Site 289. Comparisons

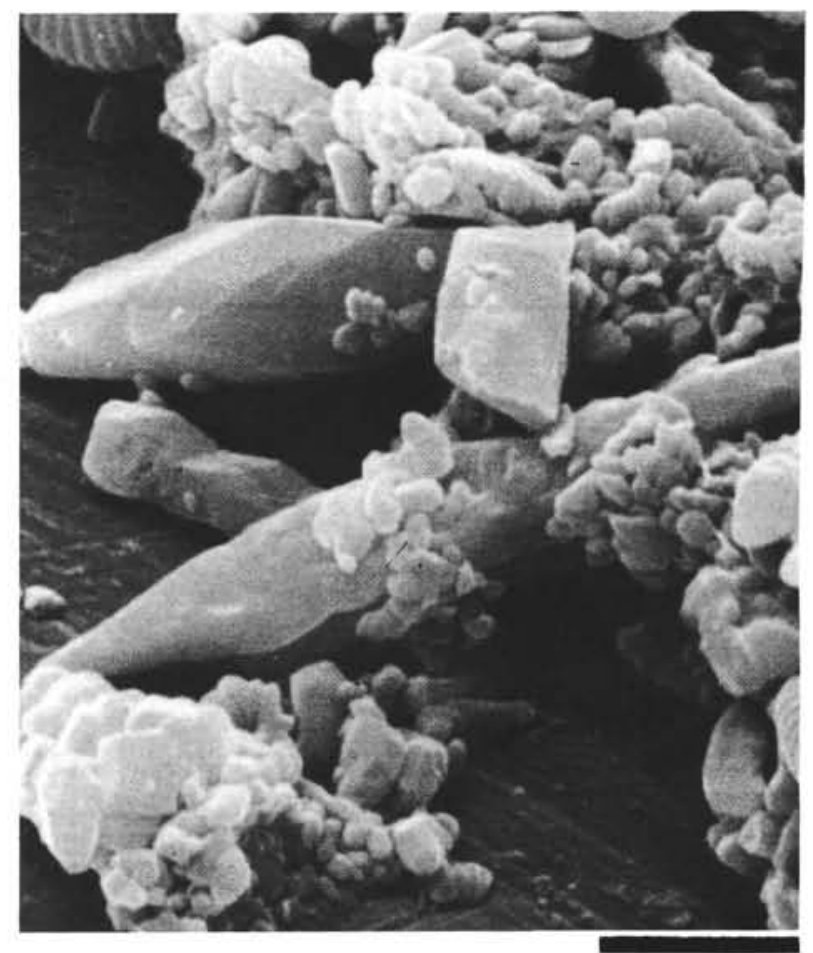

Figure 46. Site 289, 686.2 meters, late Oligocene, nannoforam chalk/ooze, porosity $(686.8 \mathrm{~m}) 51 \%$, scale bar $8 \mu$; calcareous spicules, overgrown with secondary calcite (crystal faces); identity unknown, may be calcareous sponge spicules or foraminiferal spicules.

with Site 289 will be made where appropriate in this discussion.

The highest reflector is at a depth of 46 meters subbottom in upper Pliocene sediments. This is above the level where any diagenetic changes might be expected, and its existence might be explained by volcanic ash layers present at that depth.

The second reflector is at an estimated depth of 172 meters is middle Miocene. This is below the level at which the sediment passes from ooze to chalk, the shallowest level of this transition compared with Site 289 could be the result of erosion (the lower Pliocene is missing) or slumping (disturbance is visible on the seismic record). In the latter case dewatering of the sediment may have followed mass movement. Curiously, no reflector associated with the ooze-chalk transition is seen on the record. Although it is not lithologically explainable, there is an increase in sonic velocity at about the level of this reflector. A further increase takes place at the level of the next reflector $(215 \mathrm{~m})$ together with an increase in bulk density. The formation of diagenetic calcite was noted at 202 meters. This reflector may correspond to that at 376 meters at Site 289 .

A sonic velocity peak occurs in the vicinity of the next reflector (estimated depth, $415 \mathrm{~m}$ ) in upper Oligocene chalk. The degree of dissolution and reprecipitation of calcite increases downwards at about this level, and 


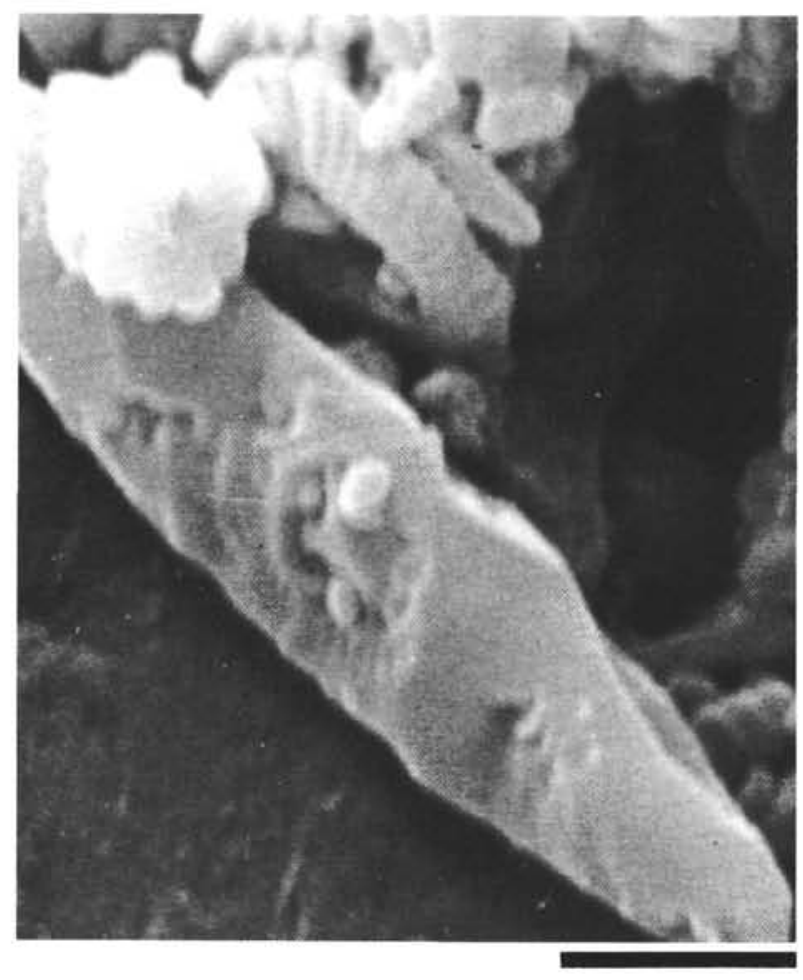

Figure 47. Site 289, 686.2 meters, late Oligocene, nannoforam chalk/ooze porosity $(686.8 \mathrm{~m}) 51 \%$, scale bar $6 \mu$; calcareous spicules as in Figure 46; note impression of coccolith in secondary calcite.

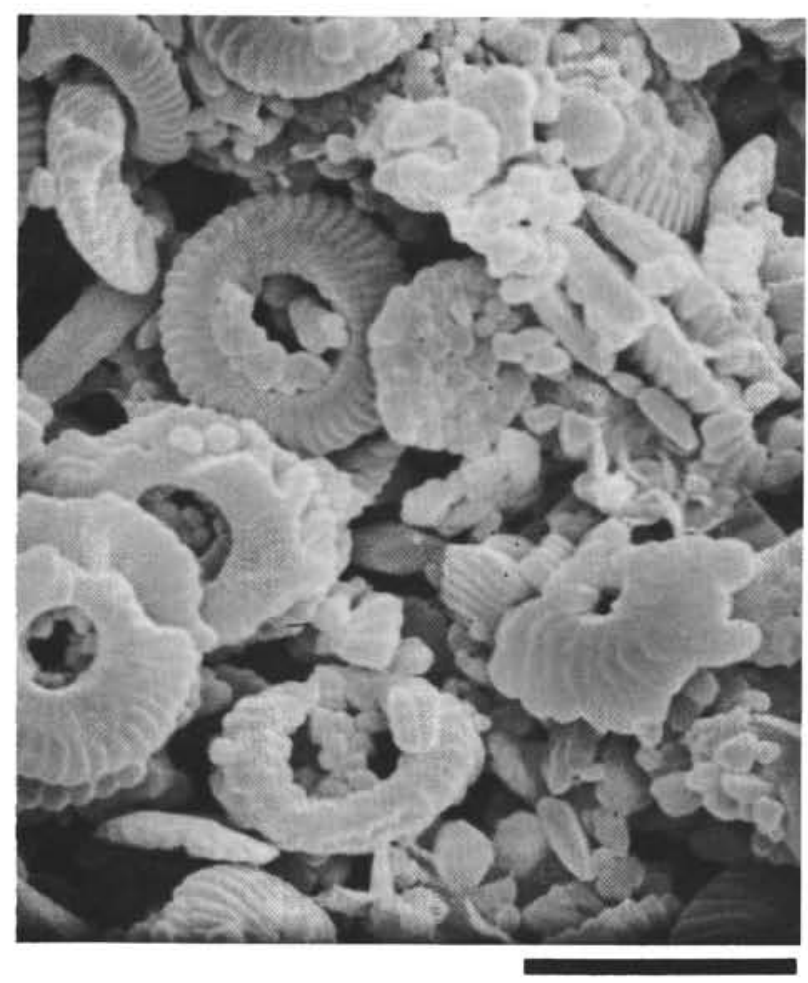

Figure 48. Site 289, 704.8 meters, late Oligocene, foramnanno chalk/ooze, porosity $(704.5 \mathrm{~m}) 47 \%$, scale bar $5 \mu$; strongly corroded coccoliths; at the same time secondary calcite growth in central areas, in between placolith shields, and on top of placoliths.

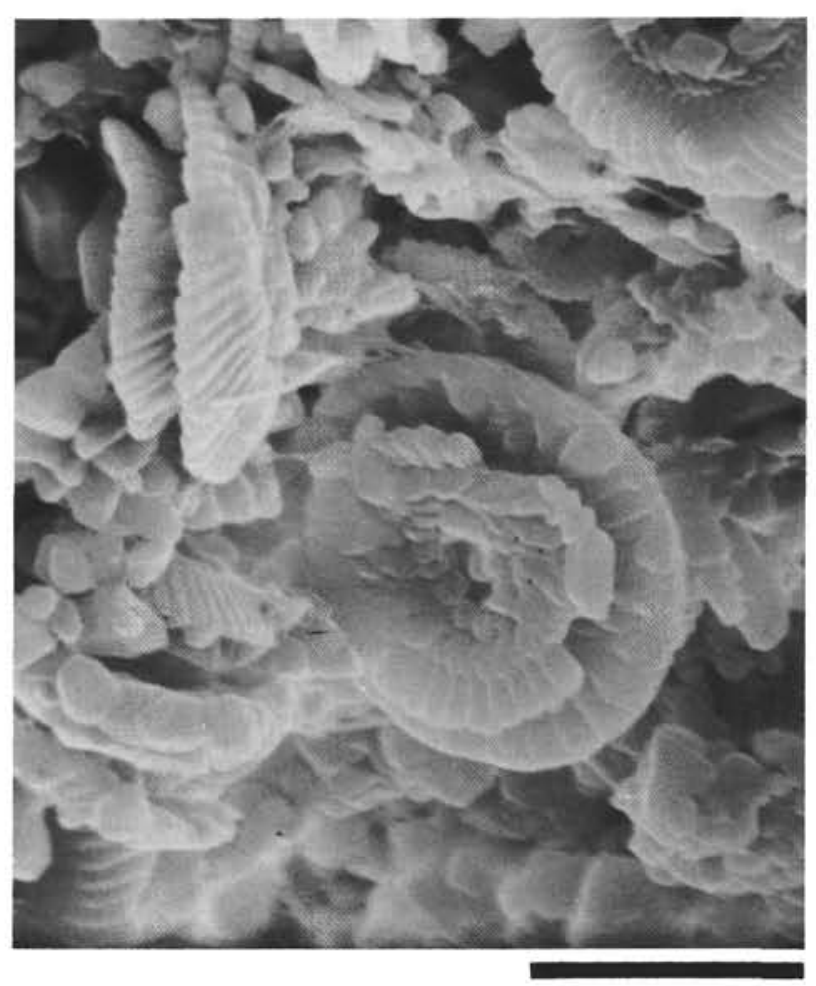

Figure 49. Site 289, 752.1 meters, late Oligocene, foramnanno chalk/ooze, porosity $(752.1 \mathrm{~m}) 49 \%$; scale bar $5 \mu$; extensive calcite overgrowth on coccoliths; particles are welded; note wisp-like bridging of particles (silica?).

cherts make a sporadic appearance. No simple explanation for this velocity peak can be offered.

The next three reflectors occurring in the chalk section have estimated depths of 617,674 , and 726 meters. The first falls within Maestrichtian beds, the second in Campanian, and the third in Santonian. The origin of these reflectors may lie in alternations in the degree of lithification as observed to be associated with reflectors at depths between 652 and 951 meters at Site 289. Depth estimates at Site 288 may not be accurate because of the paucity of data. It appears that the two lower reflectors under discussion have a calculated depth some 15 to 20 meters too shallow. If they were that much deeper, they would correspond to the top and bottom of a significant velocity excursion. The presence of chert beds in the section is extremely likely to mask the effects of carbonate diagenesis in that the reflections may be composite events.

The deepest reflection has been computed to correspond to a depth of 847 meters close to the junction between Turonian chalk and limestone. The conversion of chalk to limestone is associated at this site with substantial amounts of silicification. This reflector, however, corresponds in origin to that at 1004 meters in the upper Eocene at Site 289.

\section{CONCLUSIONS AND DISCUSSION}

From the studies of progressive diagenesis, published so far, a few clear concepts have emerged. On the other hand, several fundamental questions still remain unanswered. Some of these concepts and questions will be 


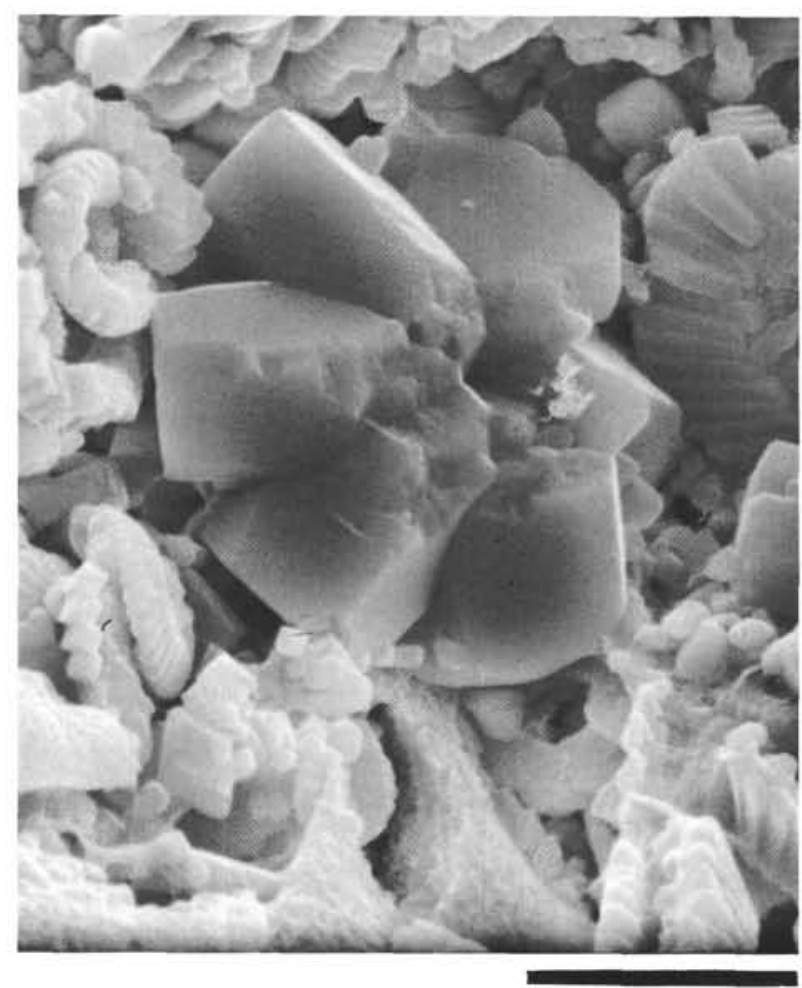

Figure 50. Site 289, 847.0 meters, late Oligocene, nanno chalk/ooze, porosity $(848.0 \mathrm{~m}) 48 \%$, scale bar $5 \mu$; overgrown discoaster, showing strong pitting; extensive calcite overgrowth on coccoliths and micarb particles; corroded radiolarian fragment at bottom of picture.

discussed briefly, referring to results from Sites 288 and 289 where appropriate.

1) For the transition of a carbonate ooze into a limestone there is no need for calcium carbonate to be introduced from an outside source. Schlanger et al. (1973) first suggested that the progressive diagenesis of carbonate sediments in the central Pacific was calcite conservative. Matter (1974) came to the same conclusion for sediments in the Arabian Sea.

2) As reported earlier in this paper, Schlanger et al. (1973) proposed a model for carbonate diagenesis. Their model suggests that 3-cc carbonate ooze (density 1.35; porosity 80 ) first changes to $1.7-\mathrm{cc}$ chalk (density 1.60 ; porosity 65 ), which finally gets transformed into 1-cc limestone (density 2.0; porosity 40 ). This model can be compared with data from Sites 288 and 289.

At Site 288 the uppermost carbonate sediments have a bulk density of about 1.6, and a porosity of between 65 and 70. At Site 289 these figures are between 1.5 and 1.6, and between 65 and 70 , respectively. Both sites thus have a higher density and lower porosity than the ooze in the Schlanger et al. model. As intraparticle porosity (especially from foraminifera) can contribute substantially to overall porosity and density, this difference might be explained by differences in foraminifera percentages in the sediments. The model of Schlanger et al. was based on data from Site 167. At that site

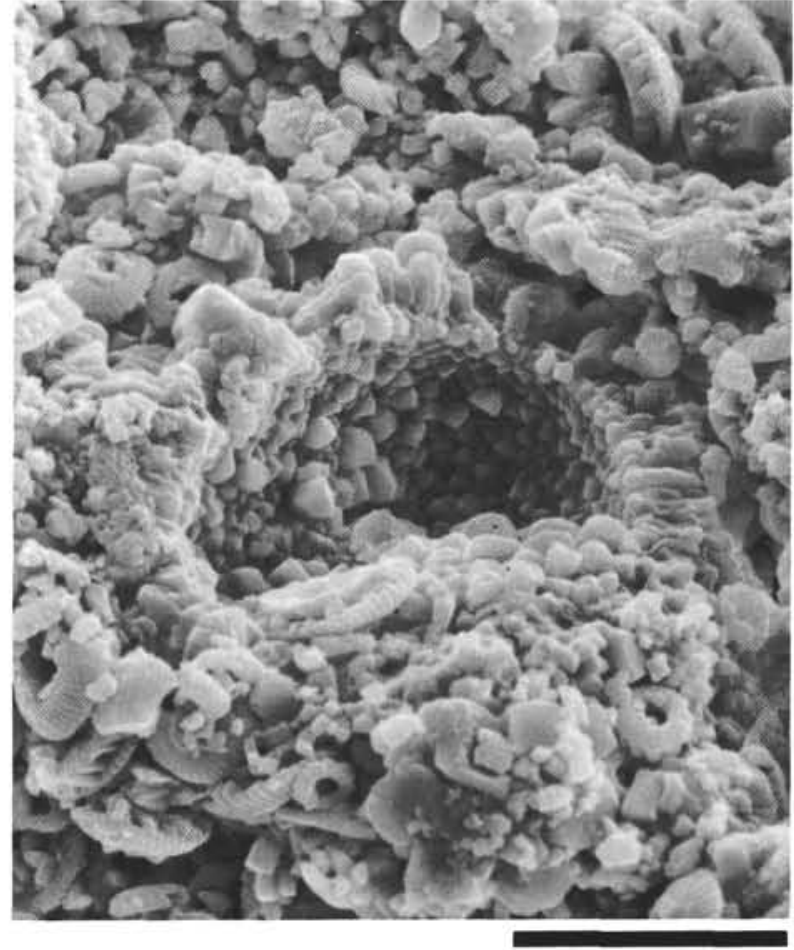

Figure 51. Site 289, 847.0 meters, late Oligocene, nanno chalk/ooze, porosity $(848.0 \mathrm{~m}) 48 \%$, scale bar $10 \mu$; foraminiferal chamber showing advanced stage of calcite recrystallization of walls and inner space; surrounding sediment also shows abundant new calcite formation.

foraminifera are present in abundance (numerical estimates of sediment components became routine practice in the DSDP only from Leg 21 onwards). However, in the top parts of the sequences at Sites 288 and 289, foraminifera are also present in abundance. Water depths cannot explain the differences either ( $3176 \mathrm{~m}$ at Site 167, $3000 \mathrm{~m}$ at Site 288, and 2206 at Site 289).

The equivalent stage to the Schlanger et al. intermediate chalk stage was reached at a depth of about 300 meters at Site 167. At Site 288 this stage (as far as density and porosity are concerned) is already reached at 50 meters, and at Site 289 at 100 meters. Both levels are still in the ooze interval.

Things become more complicated in the limestone intervals at Sites 288 and 289, due to the presence of silica and volcanic material. The siliceous limestone at Site 288 (lowermost $150 \mathrm{~m}$ ) has density values fluctuating between 2.2 and 2.4 . Porosity values vary between $20 \%$ and $30 \%$. The last relatively pure carbonate sediment occurs at about 600 meters, which is still in the chalk interval. At 609.9 meters, the calcium carbonate percentage is $96 \%$, the density 1.86 , and the porosity $51 \%$. In the limestone interval, the highest calcium carbonate percentage ( $80 \%$ ) was recorded at 858.6 meters. The density at that level is 2.20 and the porosity 27 . At Site 289 the limestone interval has density values fluctuating between 2.0 and 2.4 , and porosity values between $15 \%$ 


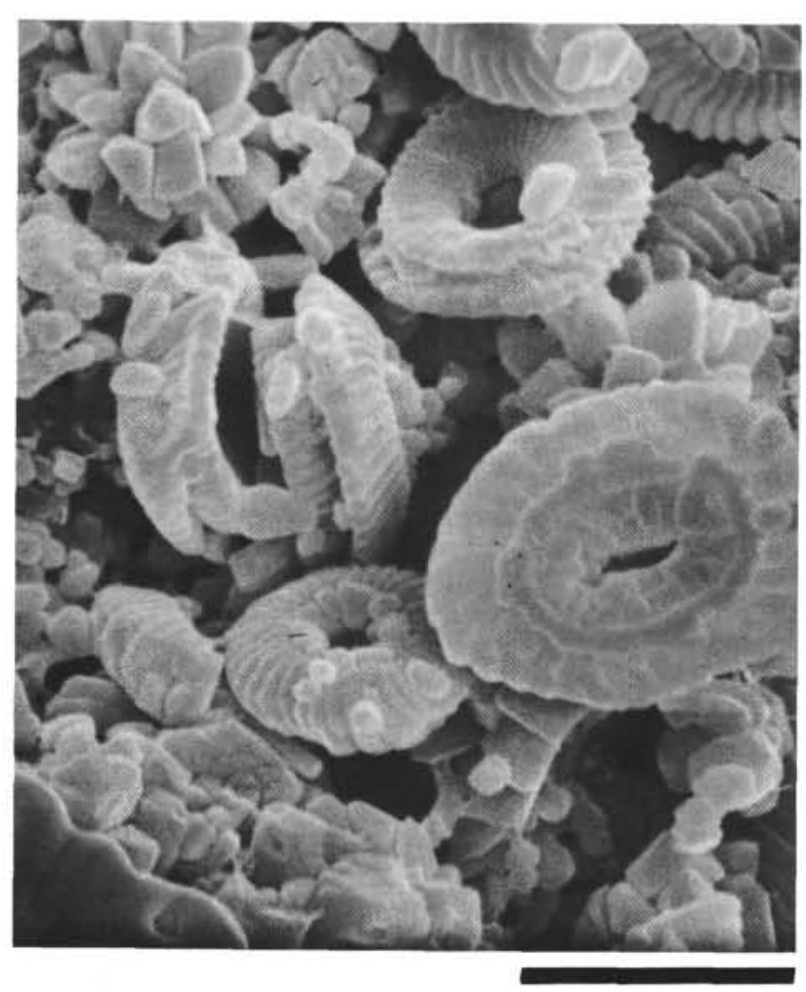

Figure 52. Site 289, 886.2 meters, early Oligocene, foram-nanno chalk, porosity $(886.2 \mathrm{~m}) 48 \%$, scale bar $5 \mu$; coccoliths show dissolution and reprecipitation of calcite; radiating clusters of subhedral calcite crystals are the nannofossil Sphenolithus moriformis; note welding of particles; amorphous substance at lower left corner is probably fungus growth.

and $40 \%$. The lowermost part of this interval has relatively pure carbonate horizons. For instance, at 1167 meters, the calcium carbonate percentage is $99 \%$. The density at this level is 2.22 , and the porosity is 26 .

In the Schlanger et al. model, the sediment is compacted to a third of its original volume during the transition from ooze to limestone. A similar type of calculation that forms the basis of their model can be applied to, for instance, Site 289. Provided no calcite has been introduced from outside, $10 \mathrm{cc}$ of ooze (density 1.55, porosity $70 \%$ ) has changed to about $4.3 \mathrm{cc}$ of limestone (density 2.22 , porosity $26 \%$ ). This is a compaction to less than half the original volume. Keeping in mind that the ooze at the top of Site 289 is already more compacted than the ooze in the model, numerically the compaction compares closely with the model.

There are, however, several pitfalls in this type of approach. Firstly, it is not certain that the original ooze which is now compacted to limestone, had the same density and porosity at the time it was close to the sedimentwater interface, as the present-day ooze. Secondly, the proviso of the system being calcite conservative as a whole does not mean that within the system calcite cannot move from one horizon to another. That this takes place is suggested by the presence of stylolites and claycoated slickensides. The formation of chert nodules,

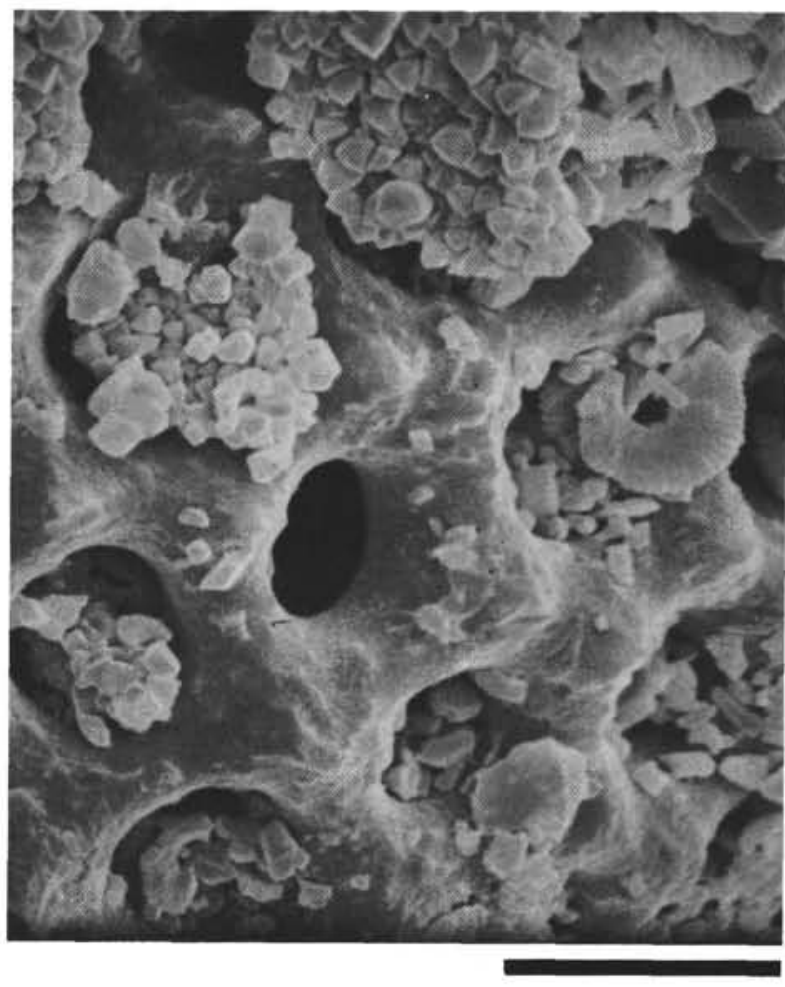

Figure 53. Site 289, 914.3 meters, early Oligocene, nanno-foram chalk, porosity $(914.8 \mathrm{~m}) 47 \%$, scale bar 10 $\mu$; compare with Figure 43; strongly corroded radiolarian, covered with euhedral micarb particles.

through the exchange of calcite for silica, must also have resulted in zones richer in calcium carbonate.

However, keeping in mind these problems, it can fairly be stated that considerable compaction takes place during diagenesis. This compaction does take place not so much by crushing of microfossil tests (such as foraminifera) as by disintegration of larger microfossils into smaller particles (micarb) through dissolution; by closer packing of particles; and by interpenetration of particles through pressure solution. This might in part provide an answer to the problem, stated by Bathurst (1969), that no obvious signs of compaction (e.g., crushed foraminiferal tests) can be detected in many lithified carbonate muds (micrites) and that consequently the large amount of calcite cement, filling the pore space, must have come from an outside source.

3) Dissolution and reprecipitation within the sediment takes place simultaneously. Whether calcite gets dissolved or acts as seed crystals depends on the form in which the calcite occurs. Physicochemical conditions of the interstitial water can change in time, shifting the balance between dissolution and reprecipitation. This may explain, for instance, the changing induration levels (chalk and ooze) at Site 289.

4) No doubt paleooceanographic water chemistry further complicates the progressive diagenetic processes. A good example is an Oligocene chalk in the Atlantic Ocean, drilled during Leg 3 of the DSDP (Wise and Kelts, 1972). This chalk has very little overburden, and is underlain by hundreds of meters of unindurated ooze (up to Cretaceous 


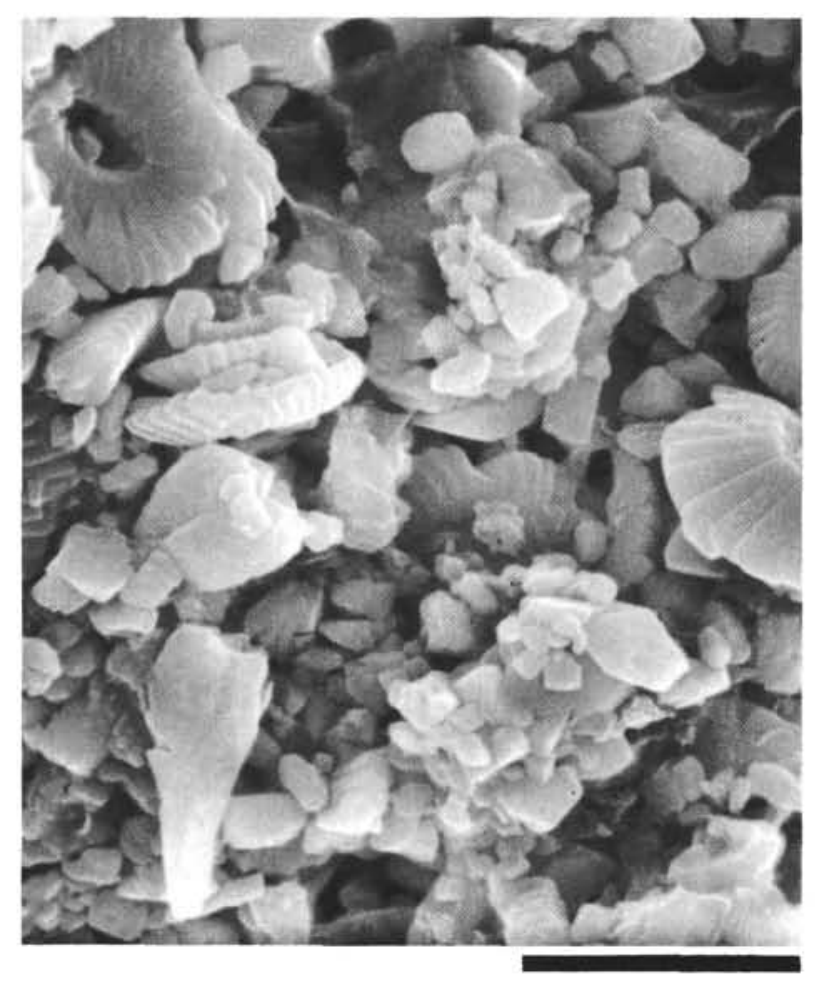

Figure 54. Site 289, 941.2 meters, early Oligocene, nanno-foram chalk/ooze, porosity $(941.0 \mathrm{~m}) 45 \%$, scale bar $5 \mu$; coccoliths show corrosion and secondary calcite overgrowth; particles are welded together with subhedral to euhedral calcite cement; note wisplike bridging structures and smooth "icing-sugar" coating of coccoliths in top part of picture (silica?).

in age). Wise and Kelts (1972) argue that induration took place soon after burial, while the sediment was still close to the sediment-water interface, and suggest that cementation was the result of paleooceanographic conditions. An interesting complicating factor is the presence of silica spherules, which Wise and Kelts think were formed after the carbonate cementation.

The ooze horizons in the Maestrichtian at Sites 288 and 289 can also best be explained by different paleooceanographic conditions. Many authors think that the worldwide existence of chert in the Eocene is also due to environmental conditions (e.g., Lancelot, 1973). Combining these two events, it would be another example of worldwide (catastrophic?) changes in Late Cretaceous-early Tertiary time. In the Australasian region the initial breakup of Gondwanaland took place during this period.

5) Lancelot (1973) suggested that chert formation is an early-diagenetic process. Wise and Kelts (1972) concluded that silica spherules in an Oligocene chalk in the Atlantic were formed after calcite cementation, thus being a late-diagenetic process. These two aspects of silica diagenesis underline the necessity, as expressed earlier by the present authors, to treat the formation of quartzose chert nodules and the formation of (cristobalitetridymite) silica spherules as two separate processes.

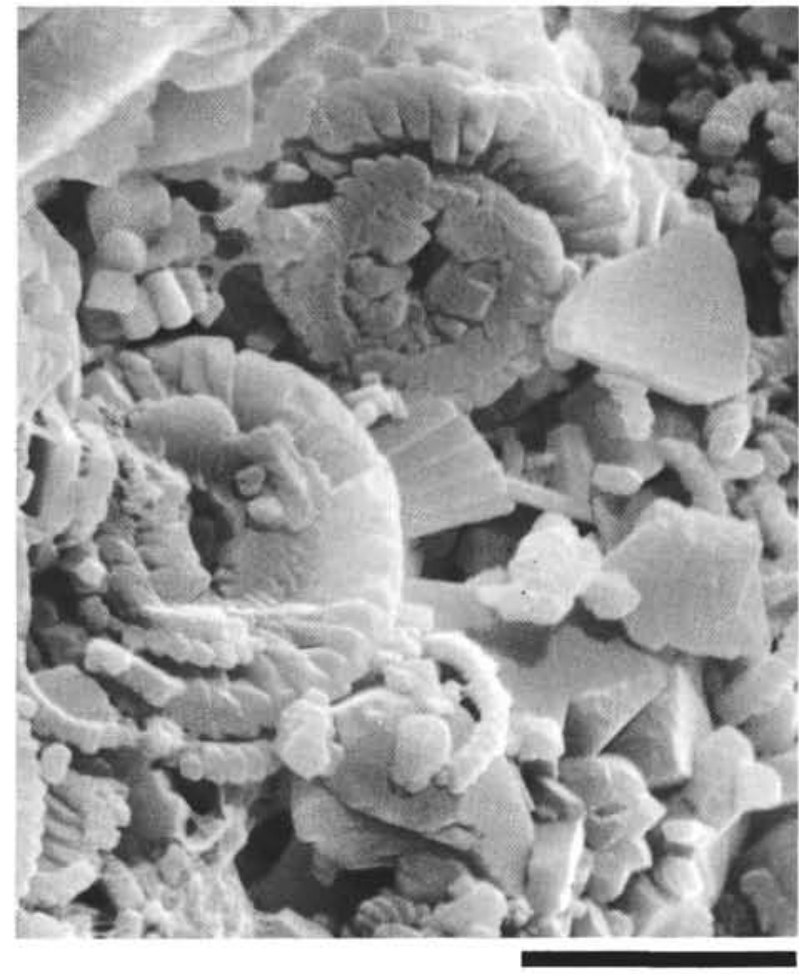

Figure 55. Site 289, 999.4 meters, late Eocene, foramnanno chalk, porosity (999.4 m) 43\%, scale bar $5 \mu$; pronounced overgrowth with secondary calcite of coccoliths, discoasters, and micarb particles; note interpenetration of calcite crystals and fossil fragments (welding); some wisp-like bridging structures (silica?) are also present.

It is difficult to find unambiguous criteria to decide whether (quartz-) silica diagenesis is an early process or not. The present authors have little to add to the excellent discussion by Lancelot (1973).

6) Another problem is the influence of silica diagenesis on carbonate diagenesis. The replacement of calcite by silica must result in calcium carbonate enrichment outside the chert nodules. This extra calcium carbonate is available for precipitation on the existing calcite substrate, or for crystallization in inter- and intraparticle pore space. If chert nodules are formed soon after burial, substantial carbonate diagenesis should then take place simultaneously.

In most deep-sea biogenic sediments chert is not present in sediments younger than Eocene. This is the case, for instance, at Site 289. At this site the carbonate sediment above the chert interval changes very gradually only. Notwithstanding an overburden of 1000 meters and a time interval of about 40 m.y., ooze horizons still exist until just above the chert-bearing interval. The various sedimentphysical properties change gradually with depth, without any jumps. The situation is quite different at Site 288, where chert is present in sediments as young as early Miocene. Carbonate-diagenetic stages, equivalent to those at Site 289, are at much shallower levels. The change from ooze to chalk is more "positive" and the physical properties graphs 


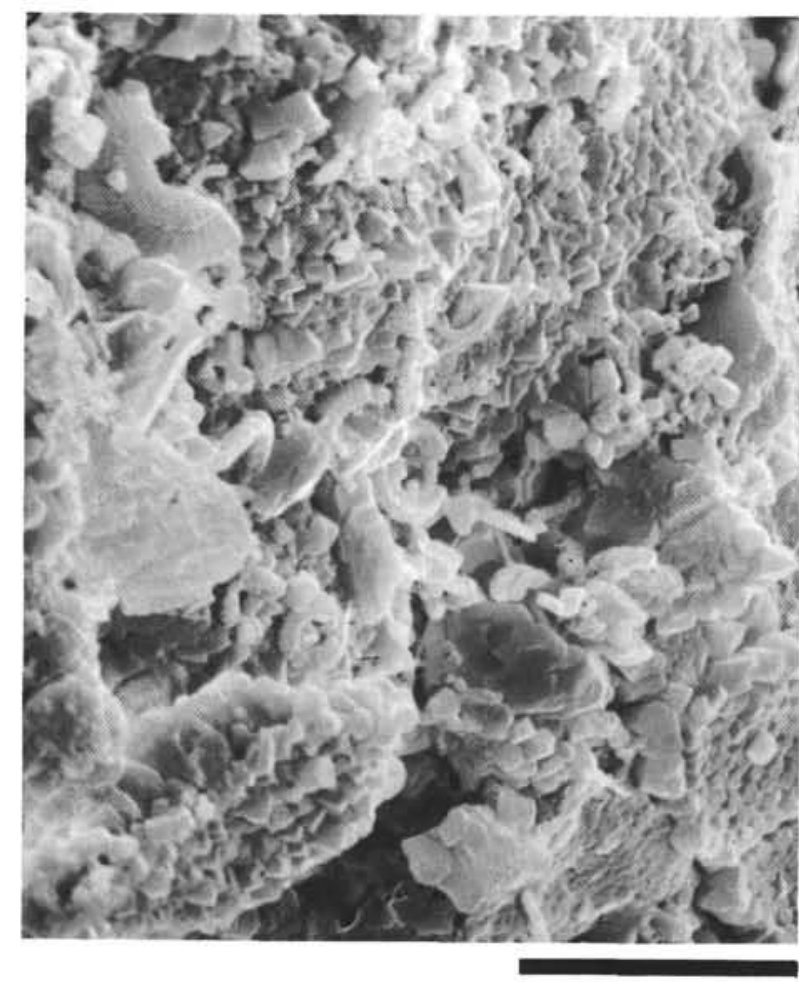

Figure 56. Site 289, 1009.0 meters, late Eocene, nannoforam limestone, porosity $(1008.8 \mathrm{~m}) 39 \%$, scale bar $10 \mu$; foraminiferal fragments, coccoliths and micarb particles welded together by extensive euhedral calcite precipitation.

show several jumps. The conclusion seems inescapable that silica diagenesis affects carbonate diagenesis.

If the above is the case, then the fact that chert is present in older sediments, or, when present in younger sediments, increases in abundance with time, could create a false impression of progressive diagenesis, dependent on time and depth of burial.

7) Heat flow is another parameter influencing diagenesis, which could create a false impression of progressive diagenesis dependent on time and depth of burial. Plate tectonics theory states that there is a relationship between the age of the oceanic crust, its depth below sea-level, and heat-flow (Sclater, 1972). This means that the first sediment deposited on newly created oceanic crust is subject to relatively high temperatures. In time, the sediment pile increases in thickness, while at the same time the heat flow decreases. Consequently, the influence of heat flow on diagenesis decreases gradually as well.

8) Notwithstanding these complicating factors, time and depth of burial play their part in diagenesis as well.

9) Another problem is the difficulty in determining how much dissolution of microorganisms has taken place in the water column during settling, at the sediment-water interface (further influenced by infaunal activity), and after burial (diagenesis proper). Pressure solution is the only type of solution which clearly has taken place after burial. Pressure solution and reprecipitation are therefore the only unambiguous indicators of "burial diagenesis."

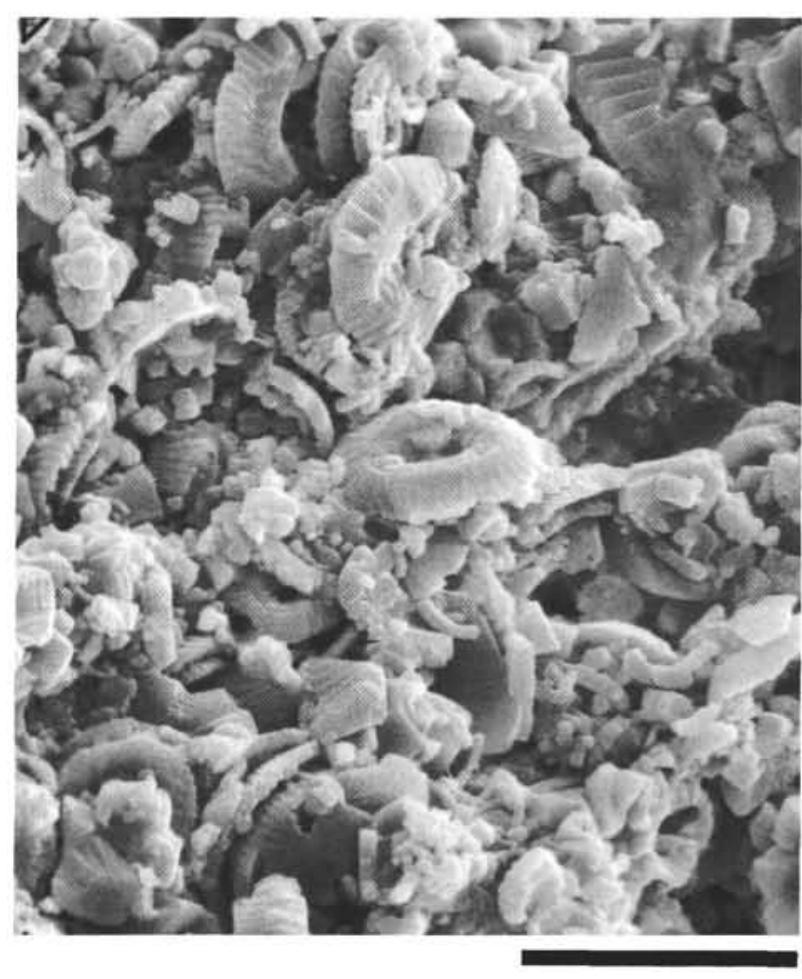

Figure 57. Site 289, 1017.2 meters, middle Eocene, nanno-foram limestone, porosity $(1017.2 \mathrm{~m}) 38 \%$, scale bar $10 \mu$; tightly packed nannofossils and micarb particles; note "icing sugar" coating (silica?) in upper right-hand corner.

10) Keeping these many complicating factors in mind, it is nevertheless possible to compose a broad picture of progressive carbonate diagenesis.

Discoasters are the first organisms to develop secondary calcite overgrowth. This starts very soon after settling. Calcite precipitation on other microfossil particles only begins after compaction and water expulsion has advanced to the stage that a grain supporting framework is established. This level is reached in the lower part of the stiff-ooze interval, where the sediment becomes crumbly. Calcite is then first precipitated along the edges and in the central areas of coccolith placoliths, and on micarb particles. This process continues and the next observable stage is the connection by secondary calcite of the proximal and distal shields of placoliths. Free-growing euhedral calcite crystals start to form inside foraminiferal chambers. Secondary calcite overgrowth continues to increase in size, developing euhedral crystal faces. Secondary calcite fills up more and more of pore space, at the same time welding particles together. In the most advanced diagenetic stage observed in deep-sea sediments, practically all fossil particles are covered with subhedral to euhedral calcite overgrowth, the central areas of coccoliths are filled "to overflowing" with granular calcite, and most remaining foraminiferal chambers are filled with secondary calcite. A large part of the pore space is filled with granular calcite cement. Porosity may have decreased from between $70 \%$ and $80 \%$ to about $25 \%$ (e.g., Site 289 ). 


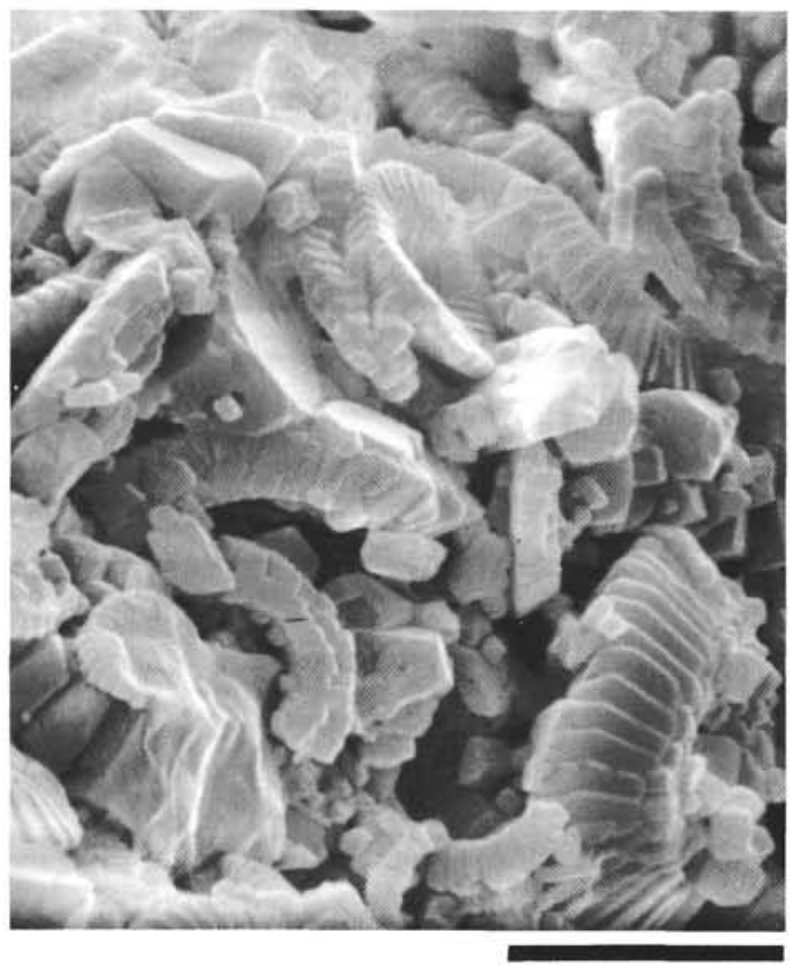

Figure 58. Site 289, 1027.1 meters, middle Eocene, foram-nanno limestone, porosity $(1027.4 \mathrm{~m}) 30 \%$, scale bar 5 5 ; advanced welding of nannofossils through calcite overgrowth and coating with "icing sugar" (silica?); note central area of coccolith filled "to overflowing" with secondary granular calcite, in lower right-hand corner.

11) Because of the highly complicated picture of silica and carbonate diagenesis, a simple set of causative diagenetic factors for seismic reflectors cannot easily be delineated. From deep-sea drilling sites in the Southwest Pacific (Packham and van der Lingen, 1973; This paper), the following list of possible correlations between sediment properties and seismic reflectors can be compiled: (a) the creamy-stiff ooze boundary, (b) the lower part of the stiff-ooze interval, where the sediment becomes crumbly, (c) the stiff-ooze-semilithified chalk boundary, where grain welding commences, (d) alternating ooze-chalk intervals, (e) the level where the bulk density starts to increase more rapidly with depth as crystal growth and solution reduce porosity, (f) the chalk-limestone boundary, (g) levels below which nonbiogenic (e.g., volcanic) material is mixed with biogenic sediment, (h) chert horizons, (i) the top boundaries of silicified sediment intervals.

\section{ACKNOWLEDGMENTS}

We wish to thank Miss R.J. Burr, University of Canterbury, Christchurch, and Mr. Allan Terrill, University of Sydney, for their assistance in taking the scanning electron photomicrographs, and printing the final photographs. We are grateful to Mr. E.T.H. Annear, New Zealand Geological Survey, Christchurch, for drafting Figures 1 and 2, and to Miss C.M. Johnstone, New Zealand Geological Survey, Christchurch, for typing the final manuscript.

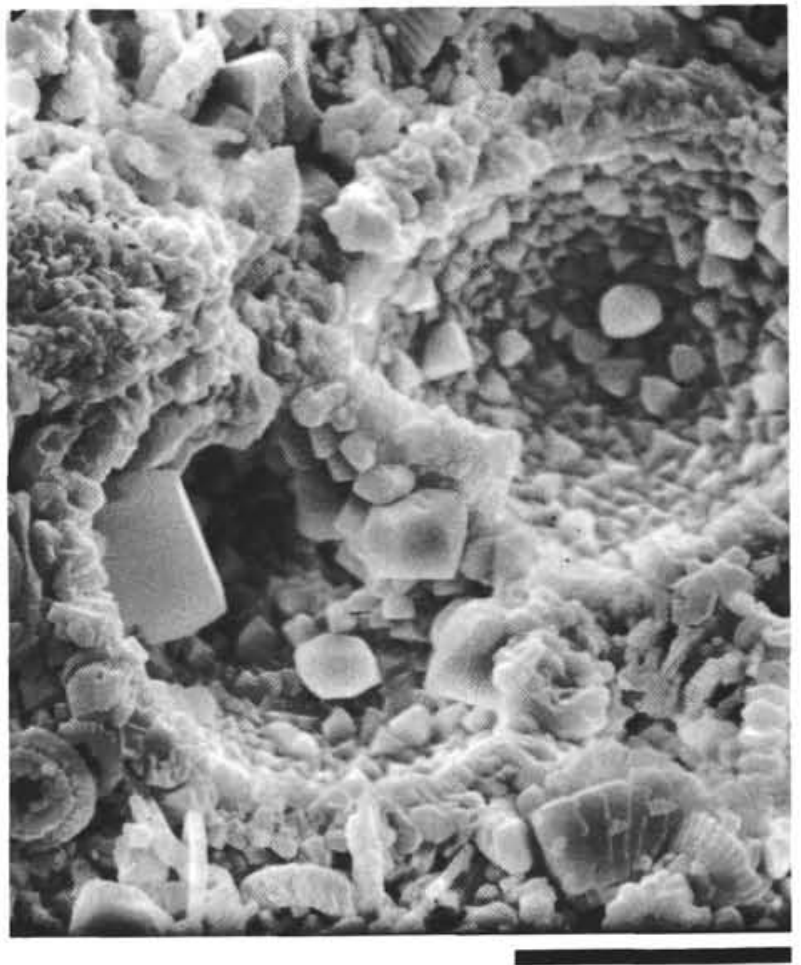

Figure 59. Site 289, 1027.1 meters, middle Eocene, foram-nanno limestone, porosity $(1027.4 \mathrm{~m}) 30 \%$, scale bar $5 \mu$; relatively large euhedral calcite crystals inside foraminiferal chambers.

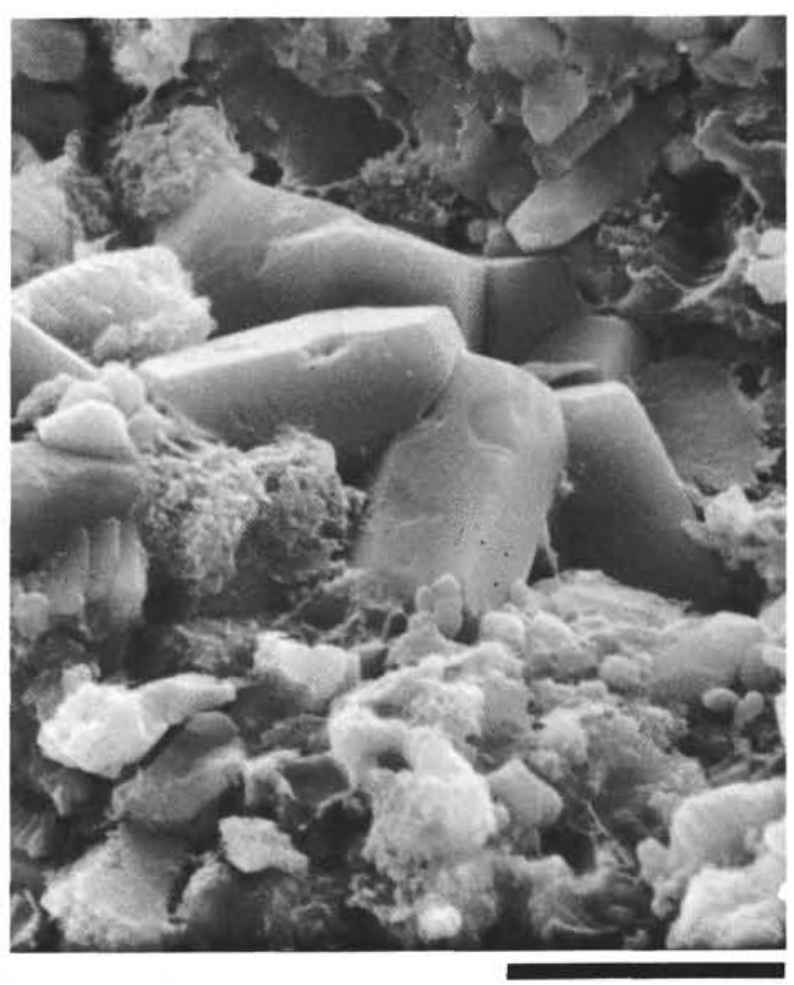

Figure 60. Site 289, 1036.8 meters, middle Eocene, nanno limestone, porosity $(1036.8 \mathrm{~m}) 22 \%$, scale bar $5 \mu$; slightly pitted overgrown discoasters, embedded in a silica groundmass; some of the silica has subspherical shapes (cristobalite?). 


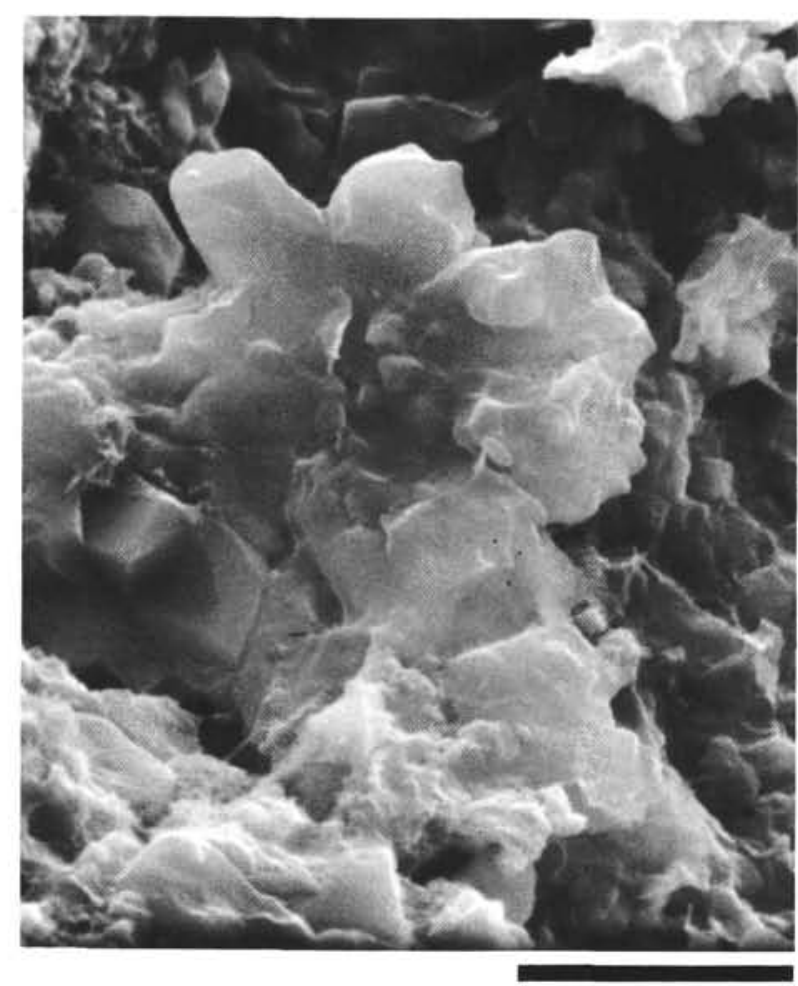

Figure 61. Site 289, 1036.8 meters, middle Eocene, nanno limestone, porosity $(1036.8 \mathrm{~m}) 22 \%$, scale bar $5 \mu$; discoasters embedded in "icing sugar" silica.

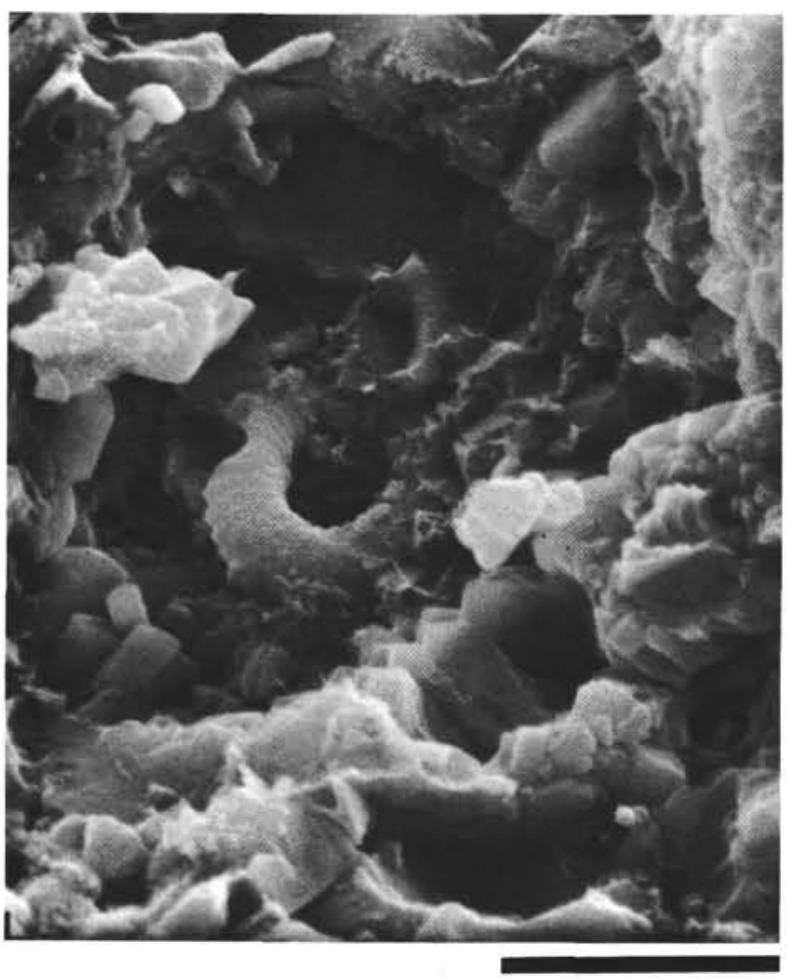

Figure 62. Site 289, 1036.8 meters, middle Eocene, nanno limestone, porosity $(1036.8 \mathrm{~m}) 22 \%$, scale bar $5 \mu$; coccoliths embedded in a dense silica matrix.

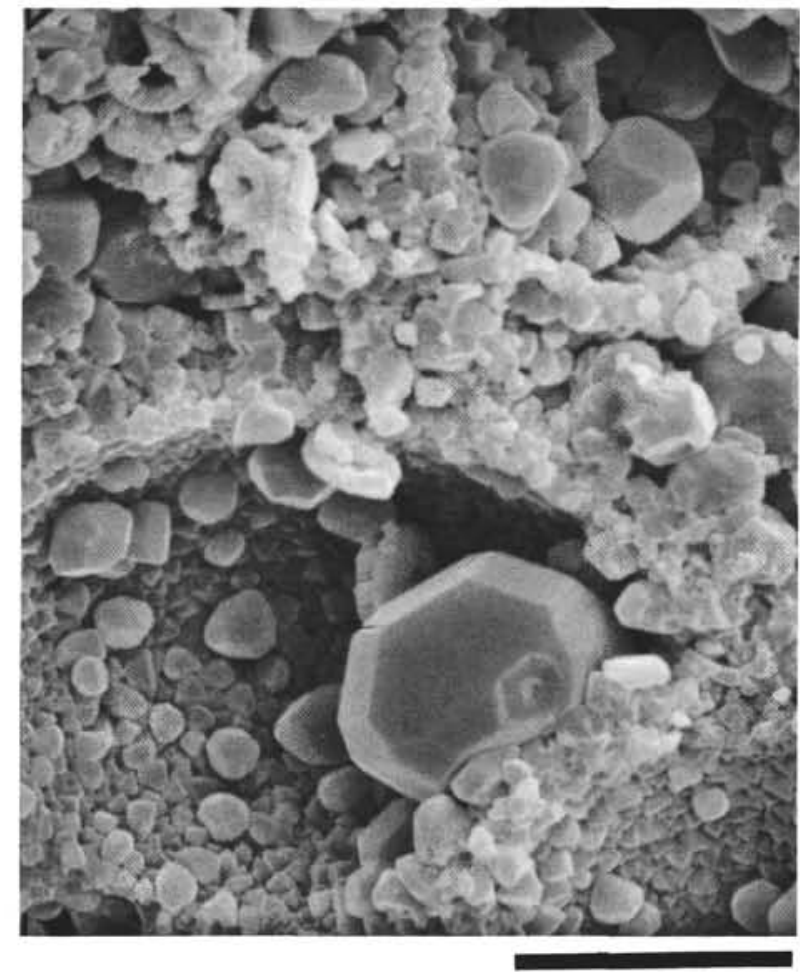

Figure 63. Site 289, 1047.2 meters, middle Eocene, nanno limestone, porosity $(1049.7 \mathrm{~m}) 19 \%$, scale bar $10 \mu$; foraminiferal chambers, partly filled with secondary euhedral calcite crystals; note "negative crystal" in largest calcite crystal.

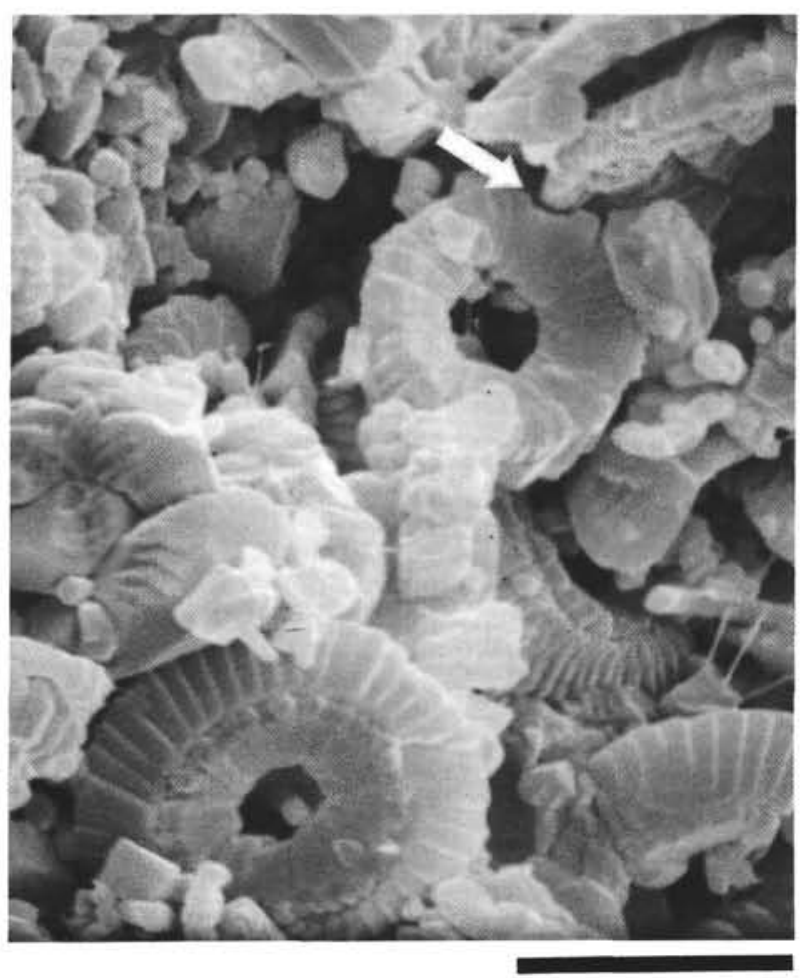

Figure 64. Site 289, 1047.2 meters, middle Eocene, nanno limestone, porosity $(1049.7 \mathrm{~m}) 19 \%$, scale bar $10 \mu$; advanced recrystallization of nannofossils; discoaster at left center shows impressions of coccoliths in the secondary calcite; note pressure solution (arrow). 


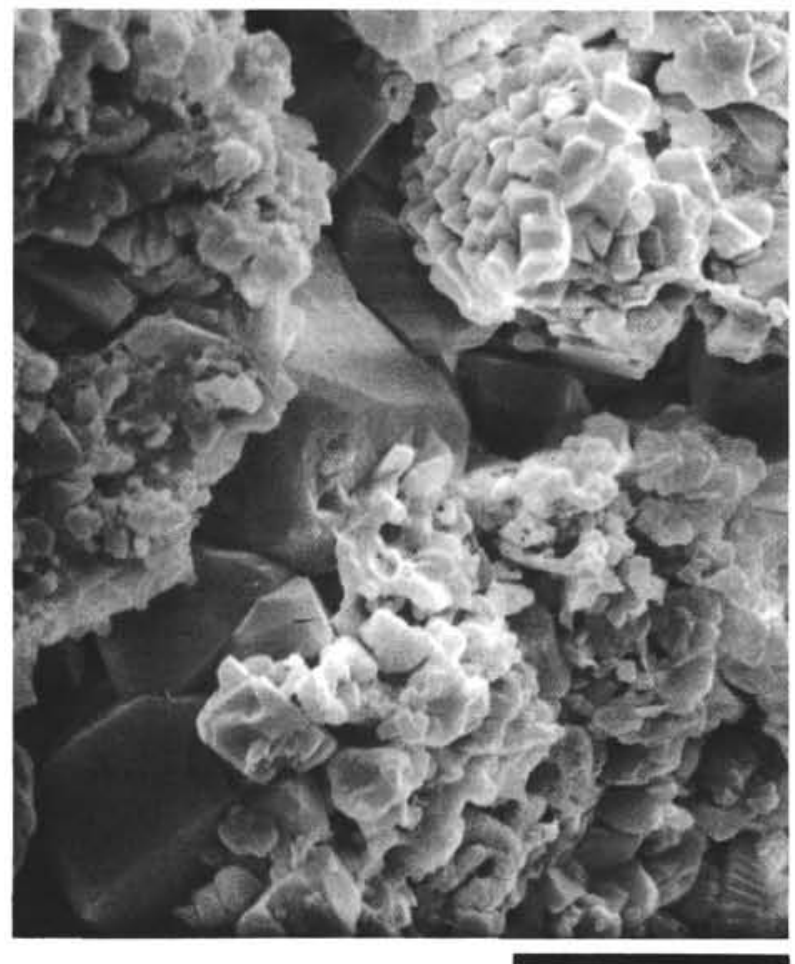

Figure 65. Site 289, 1047.2 meters, middle Eocene, nanno limestone, porosity $(1049.7 \mathrm{~m}) 19 \%$, scale bar $10 \mu$; cracks in limestone are filled with sparry calcite; note euhedral calcite overgrowth in groundmass.

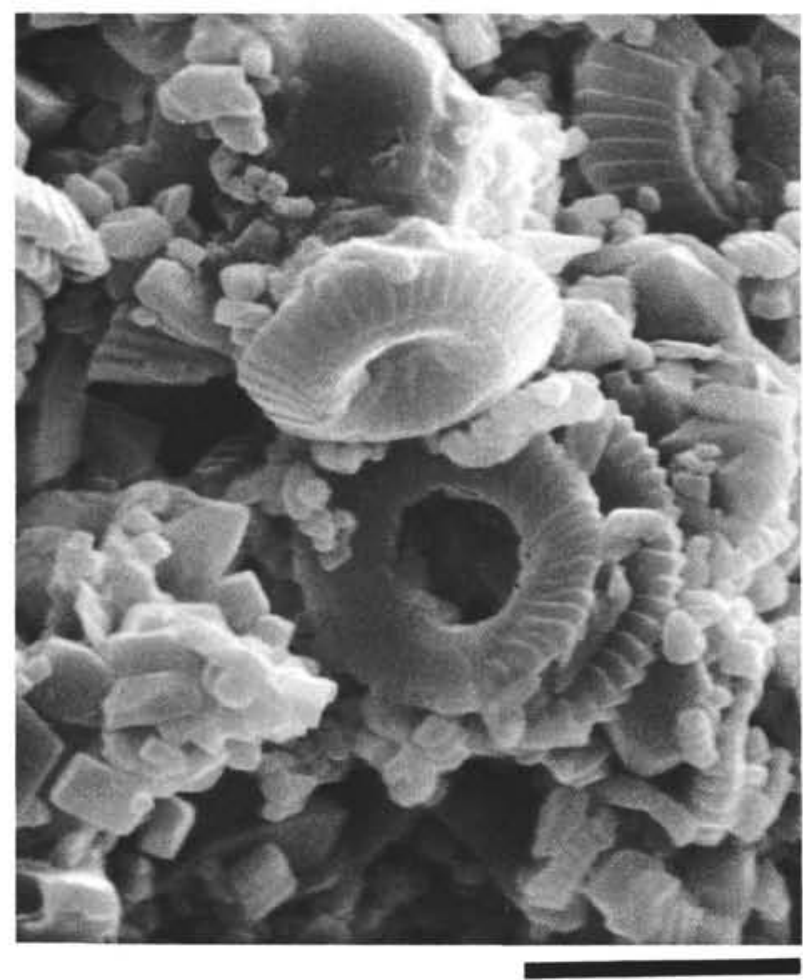

Figure 66. Site 289, 1065.2 meters, middle Eocene, nanno-foram limestone, porosity $(1065.5 \mathrm{~m})$ 23\%, scale bar $5 \mu$; coccoliths show dissolution and recrystallization; note euhedral crystal faces on granular calcite cement.

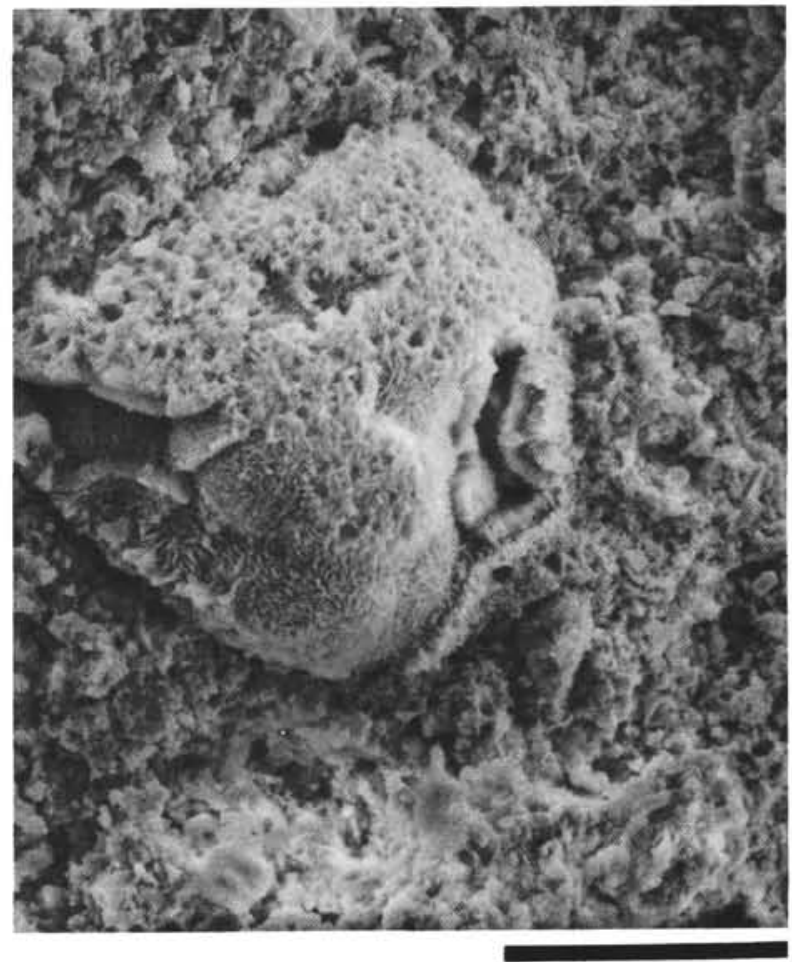

Figure 67. Site 289, 1084.2 meters, lower Eocene, siliceous limestone, porosity $(1083.9 \mathrm{~m}) 11 \%$, scale bar $30 \mu$; calcite substrate covered with a fine fibrous mineral, probably cristobalite; the same mineral is also present in the dense groundmass.

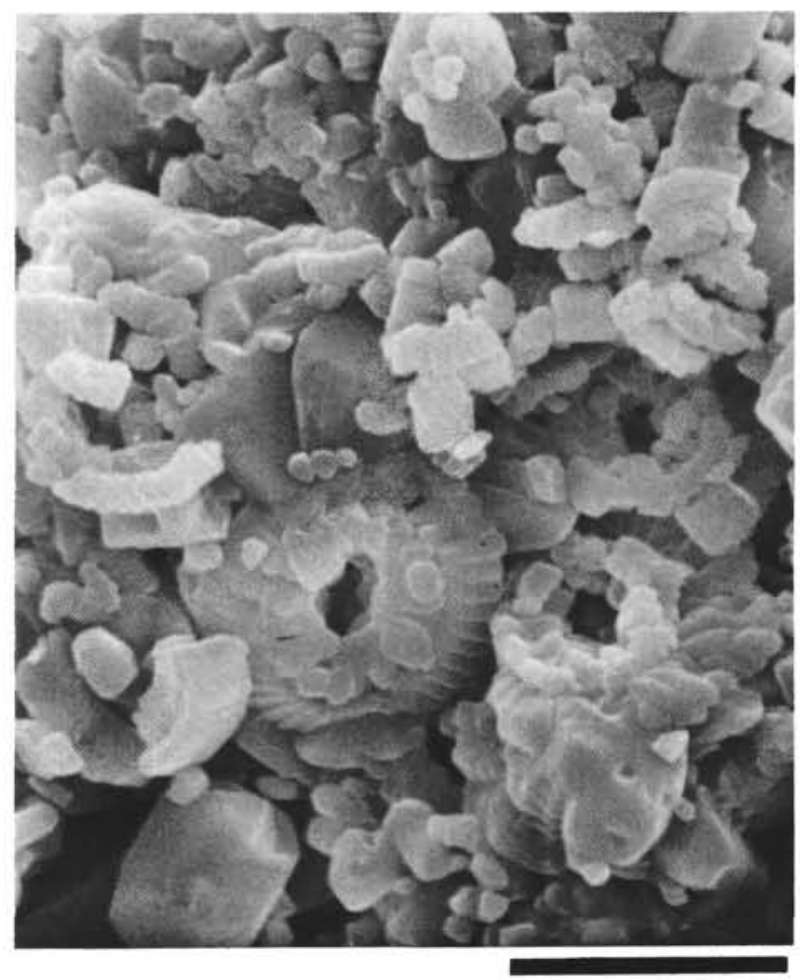

Figure 68. Site 289, 1093.8 meters, late Paleocene, limestone, porosity $(1093.6 \mathrm{~m}) 22 \%$, scale bar $5 \mu$; welded mass of nannofossils and micarb particles; advanced calcite overgrowth. 


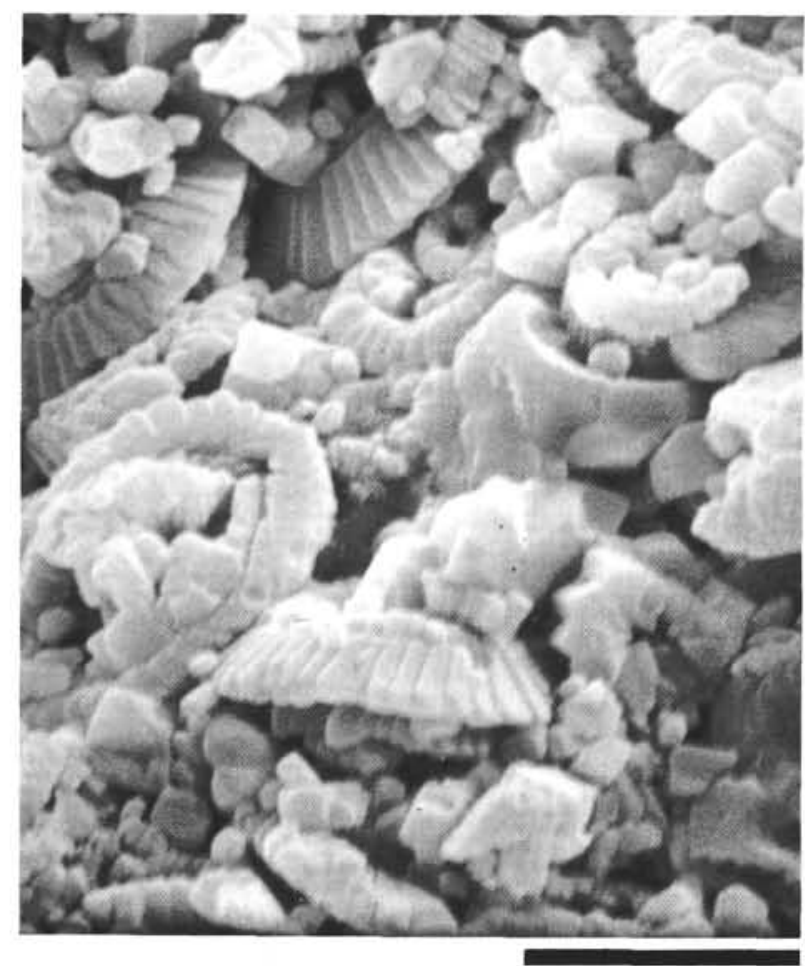

Figure 69. Site 289, 1130.5 meters, late Paleocene, foram-nanno limestone, porosity $(1131.6 \mathrm{~m}) 11 \%$, scale bar $5 \mu$; densely packed coccoliths, welded together by secondary calcite; some smooth areas (silica coating?) are visible just right of center.

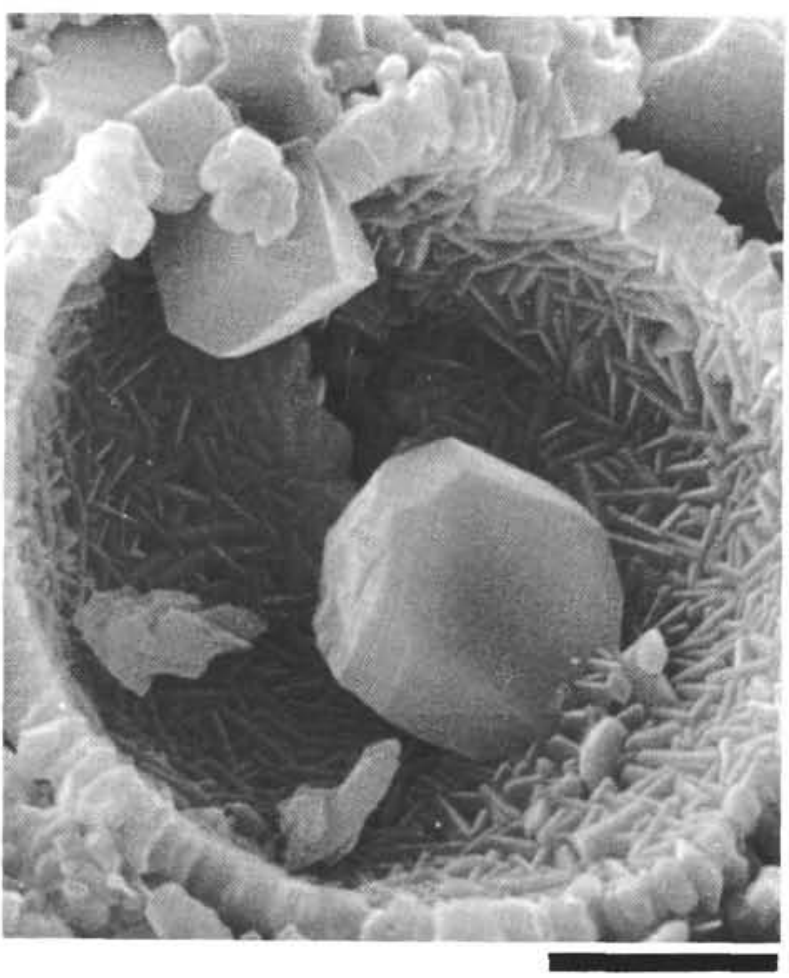

Figure 70. Site 289, 1131.6 meters, late Paleocene, limestone, porosity $(1131.6 \mathrm{~m}) 11 \%$, scale bar $10 \mu$; inner surface of foraminiferal chamber covered with rod-like crystals (calcite?); also free-growing euhedral calcite crystals.

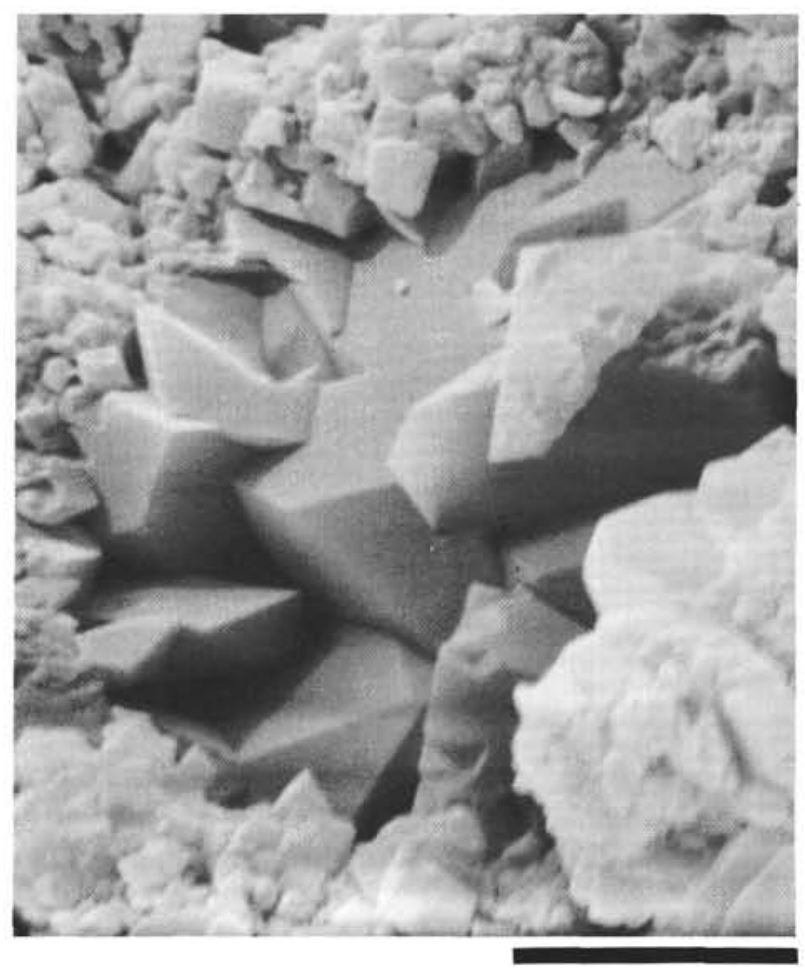

Figure 71. Site 289, 1131.6 meters, late Paleocene, limestone, porosity $(1131.6 \mathrm{~m}) 11 \%$, scale bar $5 \mu$; foraminiferal chamber, completely filled with interlocking calcite (?) crystals; note recrystallized chamber wall.

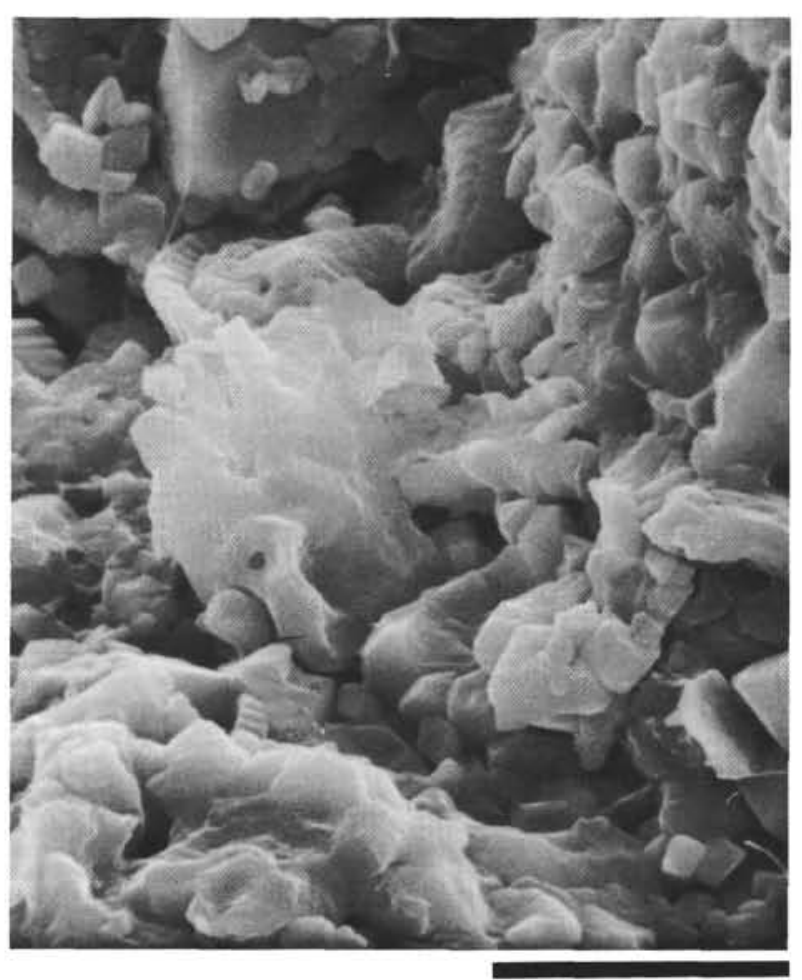

Figure 72. Site 289, 1138.1 meters, early Paleocene, limestone, porosity $(1138.2 \mathrm{~m}) 7 \%$, scale bar $5 \mu$; nannofossils embedded in dense ("icing sugar") silica. 


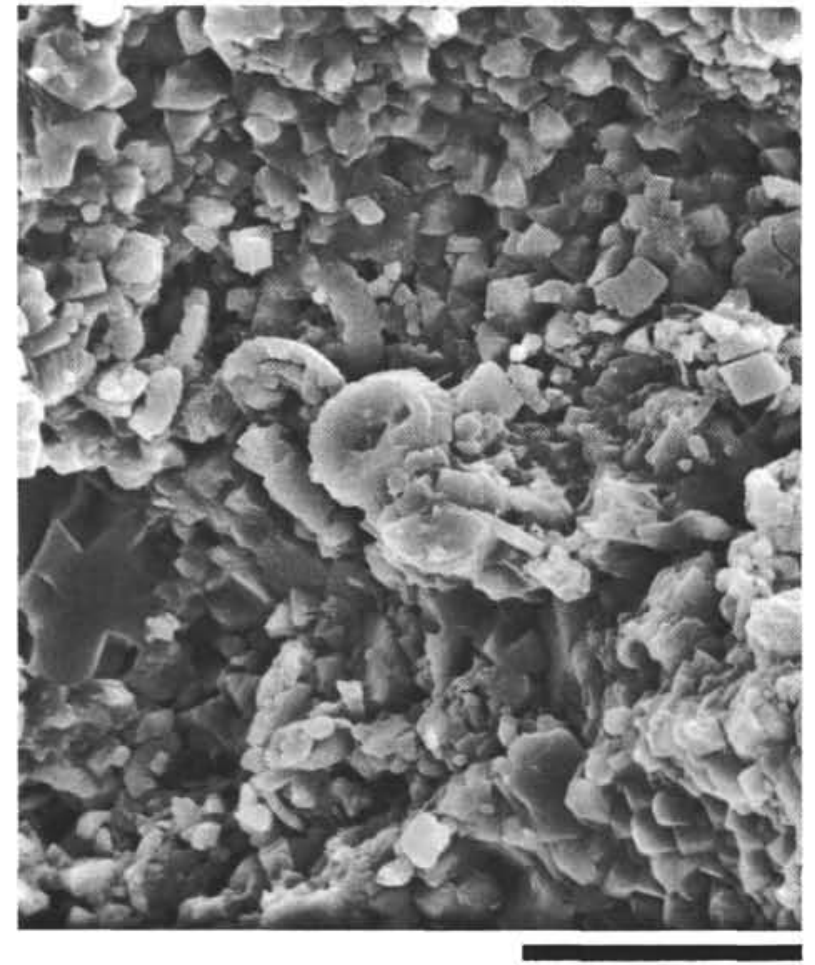

Figure 73. Site 289, 1138.1 meters, early Paleocene, limestone, porosity $(1138.2 \mathrm{~m}) 7 \%$, scale bar $10 \mu$; carbonate fossil fragments embedded in a silica matrix.

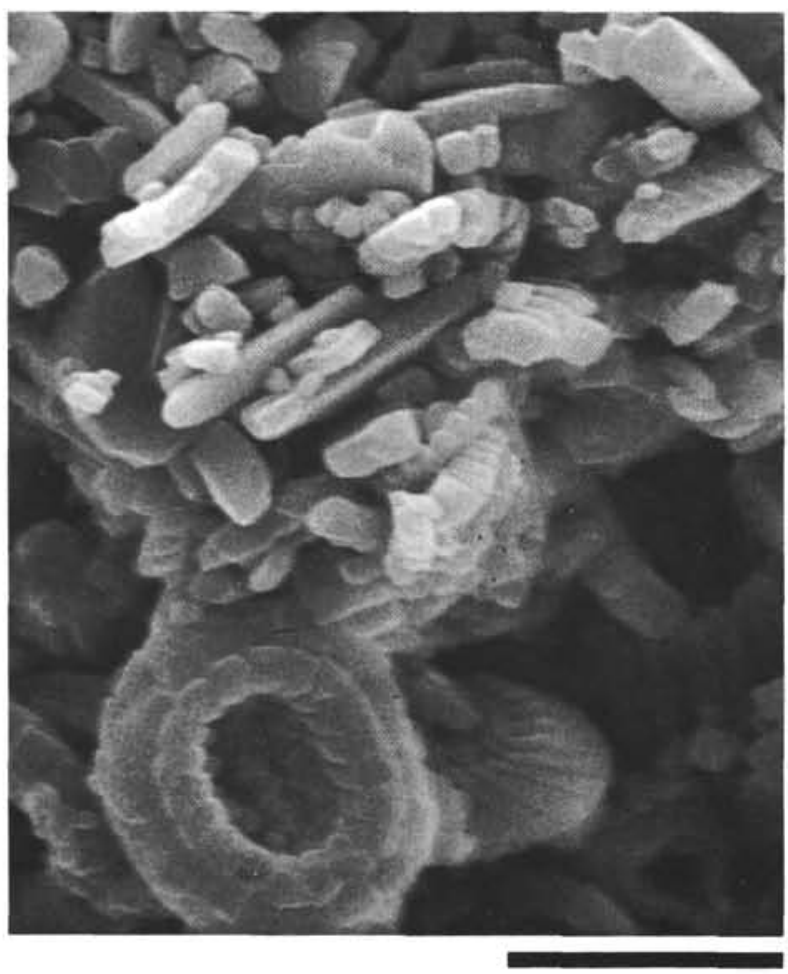

Figure 74. Site 289, 1155.8 meters, middle Maestrichtian, limestone, porosity $(1155.9 \mathrm{~m}) 40 \%$, scale bar $5 \mu$; sample shows higher porosity and less welding than samples above; still substantial secondary calcite overgrowth.

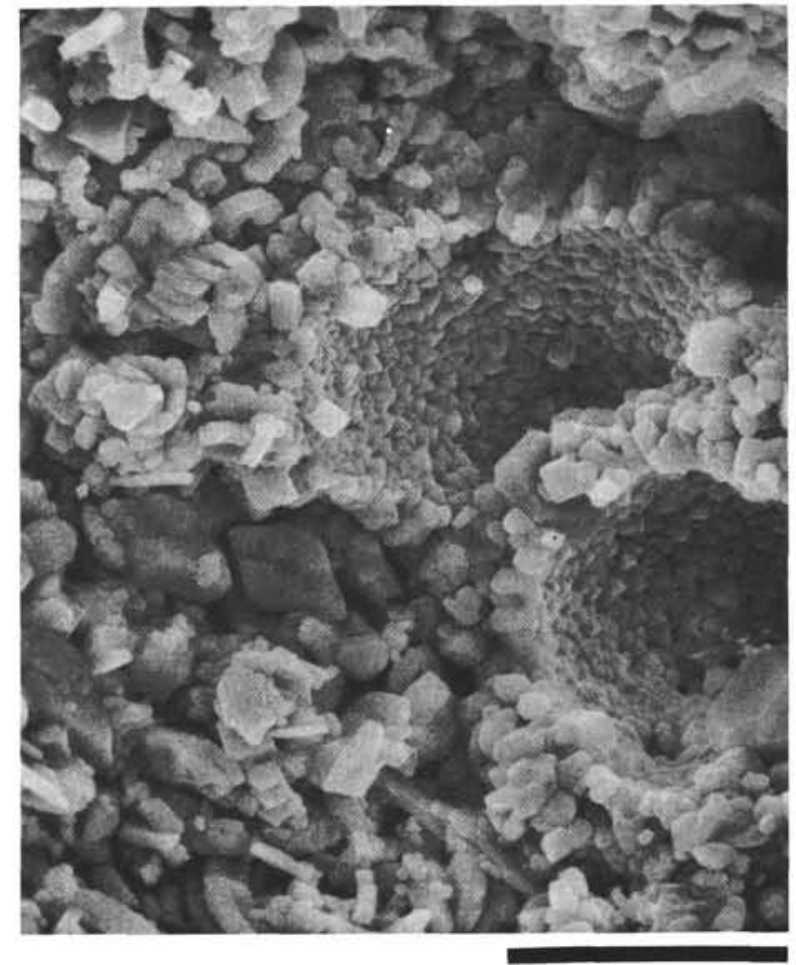

Figure 75. Site 289, 1167.4 meters, middle Maestrichtian, siliceous limestone, porosity $(1167.1 \mathrm{~m}) 26 \%$, scale bar $10 \mu$; porous packing of abundant micarb particles, surrounding a foraminifera only partly filled with secondary calcite.

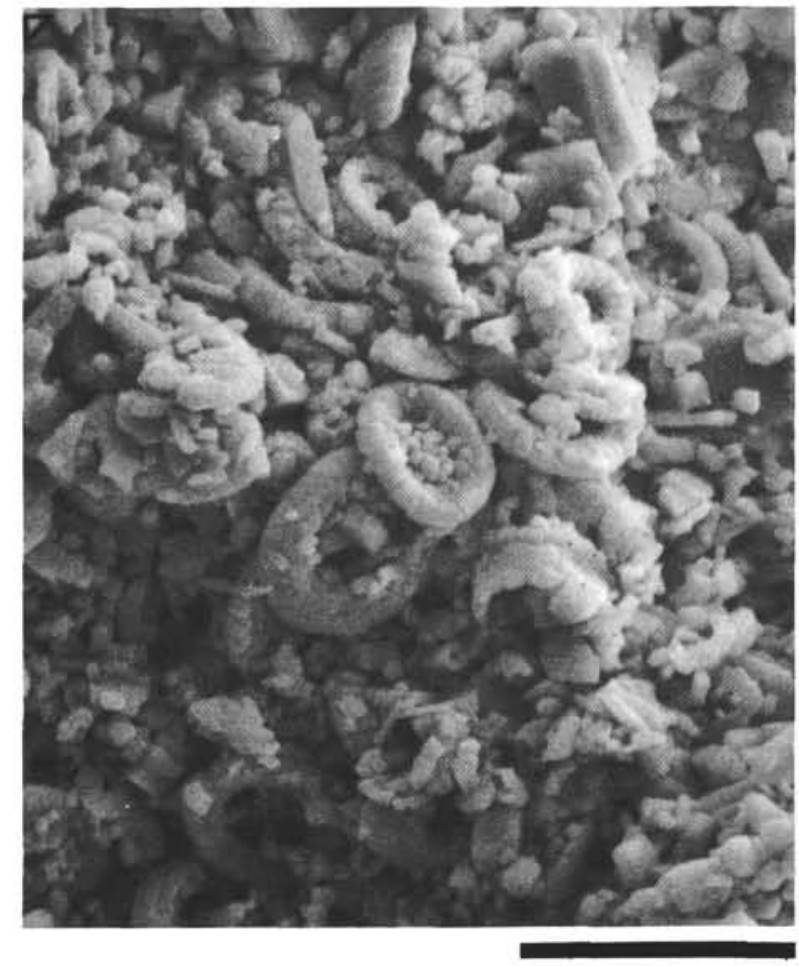

Figure 76. Site 289, 1175.3 meters, middle Maestrichtian, siliceous limestone, porosity $(1175.3 \mathrm{~m}) 38 \%$, scale bar $10 \mu$; micarb particles and relatively well preserved coccoliths; limited welding. 


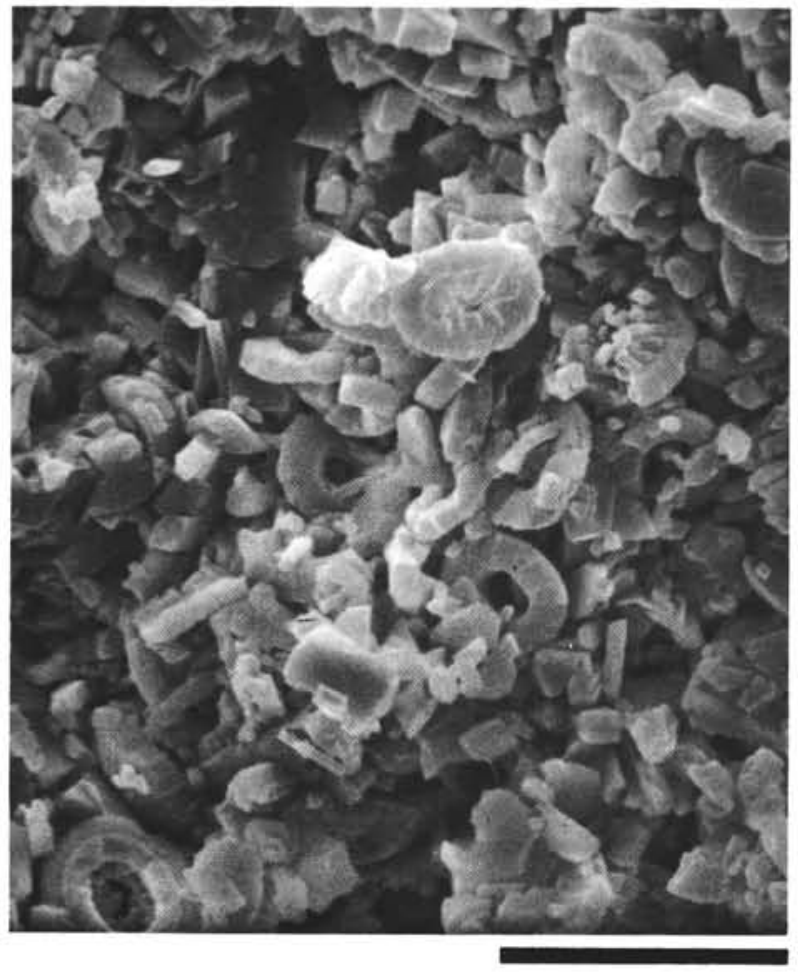

Figure 77. Site 289, 1203.9 meters, early Maestrichtian, limestone, porosity $(1203.9 \mathrm{~m}) 28 \%$, scale bar $10 \mu$; densely packed and welded angular coccoliths and micarb particles; probably silica in matrix.

\section{REFERENCES}

Adelseck, C.G., Geehan, G.W., and Roth, P.H., 1973. Experimental evidence for the selective dissolution and overgrowth of calcareous nannofossils during diagenesis: Geol. Soc. Am. Bull., v. 84, p. 2755-2762.

Bathurst, R.G.C., 1969. Problems of lithification in carbonate muds: Geol. Assoc. Proc., v. 81, p. 429-440.

Berger, W.H. and von Rad, U., 1972. Cretaceous and Cenozoic sediments from the Atlantic Ocean. In Hayes, D.E., Pimm, A.C., et al., Initial Reports of the Deep Sea Drilling Project, Volume 14: Washington (U.S. Government Printing Office), p. 787-954.

Buurman, P. and van der Plas, L., 1971. The genesis of Belgian and Dutch flints and cherts: Geol Mijnbouw, v. 50, p. 9-27.

Cheriff, O.M. and Flick, H., 1974. On the taxonomic value of the wall structure of Quinqueloculina. Micropaleontology, v. 20 , p. $236-244$.

Deer, W.A., Howie, R.A., and Zussman, M.A., 1963. Rockforming minerals. v. 4-Framework silicates: London (Longmans, Green).

Greenwood, R., 1973. Cristobalite: its relationship to chert formation in selected samples from the Deep Sea Drilling Project: J. Sediment. Petrol., v. 43, p. 700-708.

Heath, G.R., 1973. Cherts from the eastern Pacific, Leg 16, Deep Sea Drilling Project. In van Andel, T.H., Heath, G.R., et al., Initial Reports of the Deep Sea Drilling Project, Volume 16: Washington (U.S. Government Printing Office), p. 609-613.

Heath, G.R. and Moberly, R., 1971. Cherts from the western Pacific, Leg 7, Deep Sea Drilling Project. In Winterer, E. L., Riedel, W.R., et al., Initial Reports of the Deep Sea Drilling Project, Volume 7: Washington (U.S. Government Printing Office), p. 991-1007.

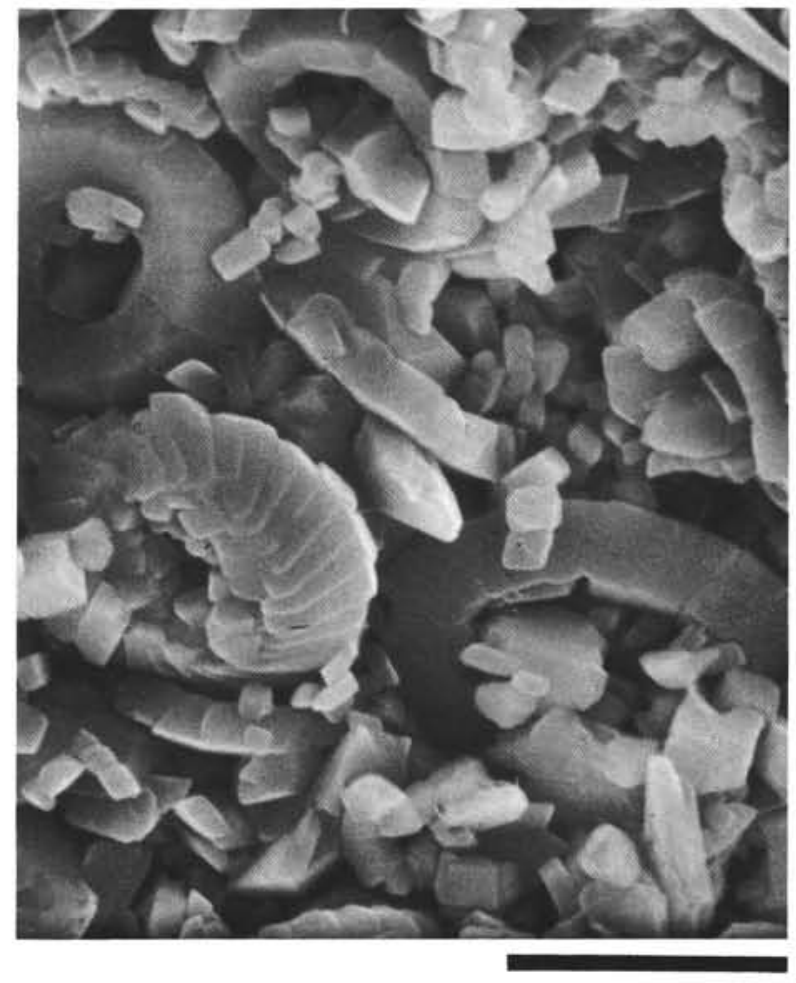

Figure 78. Site 289, 1231.0 meters, Campanian, limestone, porosity $(1231.3 \mathrm{~m}) 26 \%$, scale bar $5 \mu$; angular coccoliths showing dissolution and calcite overgrowth; relatively large subhedral granular calcite cement; a fair amount of welding has taken place; note the many rhombic micarb particles (coccolith fragments).

Hsü, K.J., 1974. In Zürich: pelagic sediments discussed: Geotimes, v. 19, p. 24.

Kastner, M. and Siever, R., 1973. Diagenesis in Mediterranean Sea core samples from Site 124-Balearic Rise, and Site 125A-Ionian Basin. In Ryan, W.B., Hsü, K.J., et al., Initial Reports of the Deep Sea Drilling Project, Volume 13: Washington (U.S. Government Printing Office), p. 721726.

Lancelot, Y., 1973. Chert and silica diagenesis in sediments from the central Pacific. In Winterer, E.L., Ewing, J.I., et al., Initial Reports of the Deep Sea Drilling Project, Volume 17: Washington (U.S. Government Printing Office), p. 377-405.

Lancelot, Y. and Ewing, J.I., 1972. Correlation of natural gas zonation and carbonate diagenesis in Tertiary sediments from the North-West Atlantic. In Hollister, C.D., Ewing, J.I., et al., Initial Reports of the Deep Sea Drilling Project, Volume 11: Washington, (U.S. Government Printing Office), p. 791-799.

Lisitzin, A.P., 1971. Sedimentation in the world ocean: SEPM Spec. Publ. No. 17.

Matter, A., 1974. Burial diagenesis of pelitic and carbonate deep-sea sediments from the Arabian Sea. In Whitmarsh, R.B., Weser, O.E., Ross, D.A., et al., Initial Reports of the Deep Sea Drilling Project, Volume 23: Washington (U.S. Government Printing Office), p. 421-469.

Moberly, R. and Heath, G.R., 1971. Carbonate sedimentary rocks from the Western Pacific: Leg 7, Deep Sea Drilling Project. In Winterer, E.L., Riedel, W.R., et al., Initial Reports of the Deep Sea Drilling Project, Volume 7: 


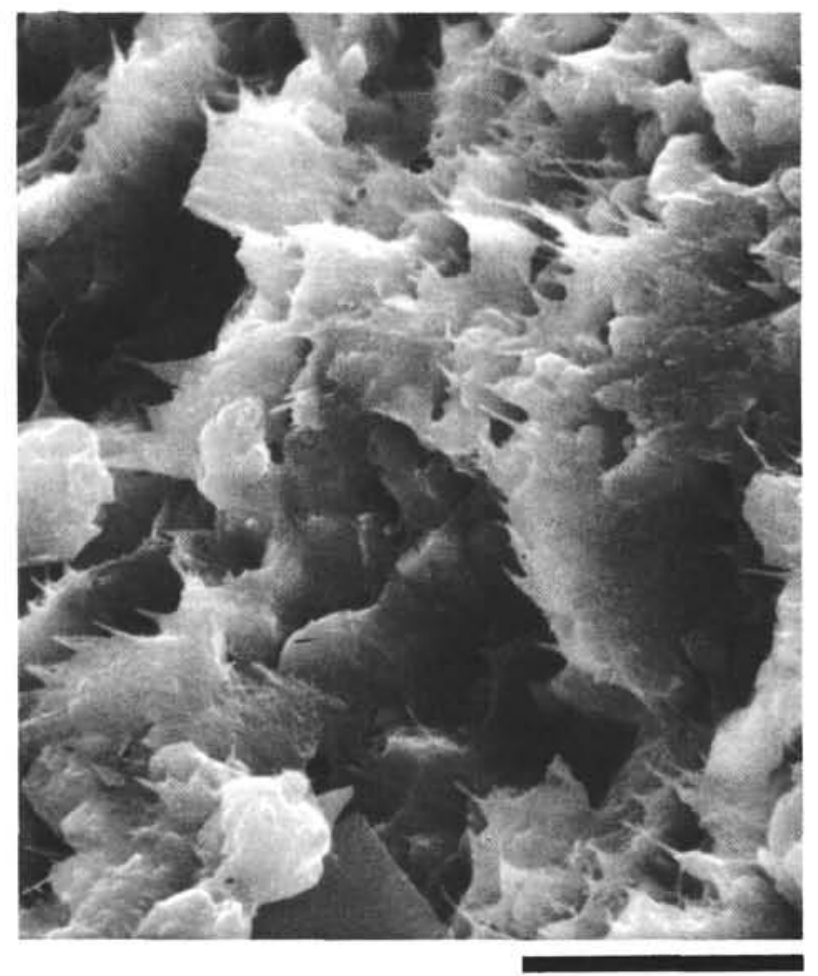

Figure 79. Site 289, 1231.6 meters, Campanian, limestone, scale bar $5 \mu$; clay-covered surface of slickensided fault.

Washington (U.S. Government Printing Office), p. 977985.

Oehler, J.H., 1973. Tridymite-like crystals in cristobalitic "cherts": Nature Physical Science, v. 241, p. 64-65.

Packham, G.H. and van der Lingen, G.J., 1973. Progressive carbonate diagenesis at deep sea drilling sites 206, 207, 208, and 210 in the Southwest Pacific, and its relationship to sediment physical properties and seismic reflectors. In Burns, R.E., Andrews, J.E., et al., Initial Reports of the Deep Sea Drilling Project, Volume 21: Washington (U.S. Government Printing Office), p. 495-521.

Pimm, A.C., Garrison, R.E., and Boyce, R.E., 1971. Sedimentology synthesis: lithology, chemistry, and physical properties of sediments in the Northwestern Pacific Ocean. In Fischer, A.C., Heezen, B.C., et al., Initial Reports of the Deep Sea Drilling Project, Volume 6: Washington (U.S. Government Printing Office), p. 1131-1252.

Schlanger, S.O., Douglas, R.G., Lancelot, Y., Moore, T.C., and Roth, P.H., 1973. Fossil preservation and diagenesis of pelagic carbonates from the Magellan Rise, central North Pacific Ocean. In Winterer, E.L., Ewing, J.I., et al., Initial Reports of the Deep Sea Drilling Project, Volume 17: Washington (U.S. Government Printing Office), p. 407427.

Sclater, J.G., 1972. Heat flow and elevation of the marginal basins of the Western Pacific: J. Geophys. Res., v. 77, p. 5705-5719.

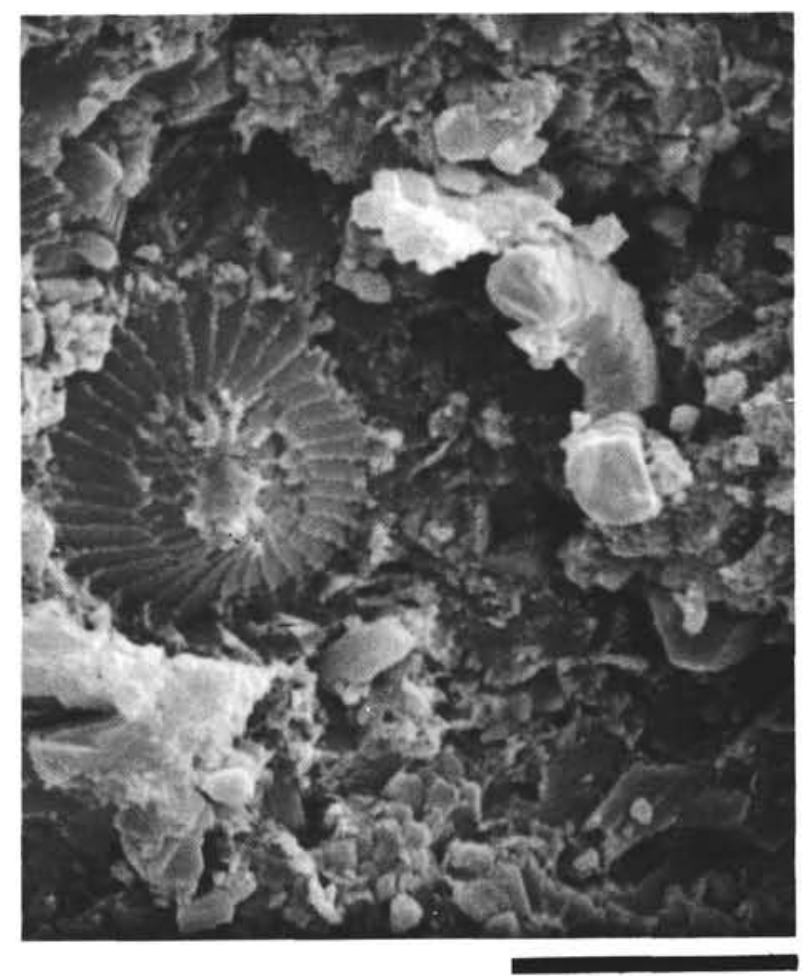

Figure 80. Site 289, 1232.7meters, Aptian, ash-bearing nanno limestone, porosity $(1233.0 \mathrm{~m}) 18 \%$, scale bar $5 \mu$; impressions of coccoliths in dense, ash-bearing matrix.

van der Lingen, G.J., Andrews, J.E., Burns, R.E., Churkin, M., Davies, T.A., Dumitrica, P., Edwards, A.R., Galehouse, J.S., Kennett, J.P., and Packham, G.H., 1973. Lithostratigraphy of eight drill sites in the Southwest Pacific-preliminary results of Leg 21 of the Deep Sea Drilling Project. In Fraser, R. (Ed.), Oceanography of the South Pacific 1972: New Zealand Commission for UNESCO, Wellington, p. 299-313.

von der Borch, C.C., Galehouse, J. and Nesteroff, W.D., 1971. Silicified limestone-chert sequences cored during Leg 8 of the Deep Sea Drilling Project: a petrologic study. In Tracey, J.I., Jr., Sutton, G.H., et al., Initial Reports of the Deep Sea Drilling Project, Volume 8: Washington (U.S. Government Printing Office), p. 819-827.

von Rad, U. and Rösch, H., 1972. Mineralogy and origin of clay minerals, silica, and authigenic silicates in Leg 14 sediments. In Hayes, D.E., Pimm, A.C., et al., Initial Reports of the Deep Sea Drilling Project, Volume 14: Washington (U.S. Government Printing Office), p. 727 751.

Wise, S.W. and Hsü, K.J., 1971. Genesis and lithification of a deep sea chalk: Ecolog. Geol. Helv., v. 64, p. 273-278.

Wise, S.W. and Kelts, K.R., 1972. Inferred diagenetic history of a weakly silicified deep sea chalk: Gulf Coast Assoc. Geol. Soc. Trans., p. 177-203.

Wise, S.W., Buie, B.F., and Weaver, F.M., 1972. Chemically precipitated cristobalite and the origin of chert: Ecolog. Geol. Helv., v. 65, p. 157-163. 